\title{
PARÂMETROS GENÉTICOS RELACIONADOS AO SISTEMA RADICULAR E À PARTE AÉREA DA SOJA [Glycine max (L.) Merrill]
}

\section{Clodoaldo José da Anunciação Filho}

Orientador: Prof. Dr. Natal Antonio Vello

Tese apresentada à Escola Superior de Agricultura "Luiz de Queiroz", da Universidade de São Paulo, para obtenção do título de Doutor em Agrono mia. Area de Concentração: Genética e Melhoramento de Plantas.

\author{
PIRACICABA \\ Estado de säo Paulo - Brasil \\ Maio - 1988
}


Anunciação Filho, Clodoaldo José da

A636p Parāmetros genéticos relacionados ao sistema radicular e à parte aérea da soja [Glycine max (L.) Merri11]. Piracicaba, 1988. 164 p. ilustradas.

Tese - ESALQ

Bibliografia

1. Soja - Melhoramento. 2. Soja - Raiz Parāmetros genéticos. I. Escola Superior de Agricultura "Luiz de Queiroz", Piracicaba.

CDD 633.34 


\title{
PARAMETROS GENETICOS RELACIONADOS AO SISTEMA
}

RADICULAR E A PARTE AÉREA DA SOJA [Glycine max (L.) Merrill]

\author{
CLODOALDO JOSE DA ANUNCIAÇÃO FILHO
}

Aprovado em 22.06.1988

Comissão Julgadora:

Prof. Dr. Natal Antonio Vello

ESALQ/USP

Prof. Dr. Paulo Sodero Martins

ESALQ/USP

Prof. Dr. Akihiko Ando

ESALQ/USP

Prof. Dr. Antōnio Roque Dechen

ESALQ/USP

Prof. Dr. Paulo Roberto de Camargo e Castro

ESALQ/USP

$$
\begin{aligned}
& y-1<1 \mid 110 \\
& y<1<1 \mid 11
\end{aligned}
$$

Prof. Dr. Natal Antonio Velio

- Orientador - 
Aos meus pais, Clodoaldo e Carmen

Aos meus irmãos, Clóvis e Carmen Lūcia

"In memorian" de Waldecira, Maria da Glória e Valdomiro,

\section{OFERECCO}

A minha esposa Maria Célia As minhas filhas Flávia, Kátia, Carmen

e Thelma,

DEDICO 


\section{AGRADECIMENTOS}

o autor agradece às seguintes pessoas e Ins-

tituições:

- Ao Prof. Dr. Natal Antonio Vello, pela orientação, confiança e amizade durante o curso.

- Ao Dr. Rildo Sartori, Diretor do Departamento de Agronomia da Universidade Federal Rural de Pernambuco - UFRPE - pela liberação ao afastamento para o Curso de Doutorado.

- Ao Prof. Dr. João Lúcio de Azevedo, pelas facilidades concedidas como Diretor do Instituto de Genética.

- A Coordenação de Aperfeiçoamento de Pessoal de Nível Superior (CAPES) e ao Conselho Nacional de Pesquisa (CNPq) pelas bolsas de estudos concedidas.

- Ao CNPq e EMBRAPA pelo financiamento das pesquisas realizadas no telado e no campo, respectivamente.

- Aos Docentes do Departamento e Instituto de Genética, pela atenção e ensinamentos recebidos.

- Ao Prof. Dr. Henrique Paulo Haag (Departamento de Química), Prof. Décio Barbin (Departamento de Matemática e Estatistica), Prof. Dr. Geraldo Victorino de França (Departamento de Solos), pelas valiosas sugestões e cordial atendimento.

- A minha esposa Maria Célia, pelo apoio, compreensão, estímulo e datilografia do rascunho.

- Ao colega e amigo Francisco Rodrigues Freire Filho, pela amizade, estímulo e cooperação na obtenção dos dados experimentais e na realização das análises genéticas no computador. 
- Ao colega e amigo Gothardo Marcon, pela amizade, apoio e cooperação na obtenção dos dados experimentais.

- Ao colega e amigo paulo H.N. Rangel, pelas sugestões e lei tura do texto.

- Aos colegas Éberson Sanches Calvo, Dario Minoro Hiromoto, Marcos Kazuyuki Kamikoga, Ana Lúcia Cruz dos Santos, Luzimar Taici Arraes Lopes, João Tomé de Farias Neto, Tumoro Sera, pela cooperação na coleta dos dados.

- Aos colegas Roberto A. Torres e Cosme D. Cruz, pela realização da análise estatística em computador.

- Aos funcionários do Setor de Genética Aplicada às Espécies

- Autógamas, Antônio Roberto Coco, Adnilson Lambertucci,clau dinei Antonio Didoné e Osmair José da Silva, pela valiosa ajuda durante a condução dos experimentos.

- Aos Senhores Sônia e Ayrton Rasera, pela amizade, atenção que nos dispensaram e pelos serviços de datilografia.

- A Bibliotecária Nilce T.P. Sigrist, pelas atenções cordiais nos atendimentos e, principalmente, pela revisão da citação bibliográfica. 


\section{SUMÁRTIO}

página

RESUMO

SUMMARY

1. INTRODUÇÃO

01

2. REVISÃO DE LITERATURA

04

2.1. Avaliação do sistema radicular (SR) ....... 04

2.2. Herdabilidade ...................... 06

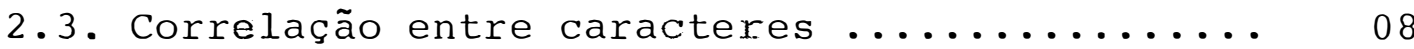

2.4. Ação gênica, variância genética e capacidade

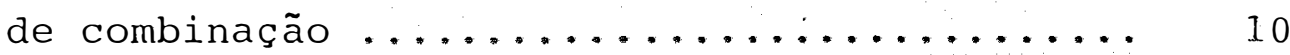

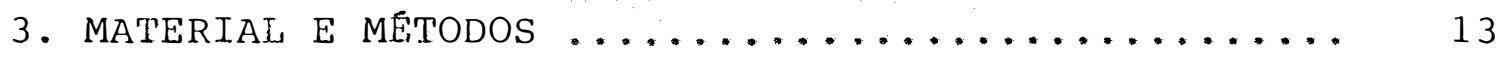

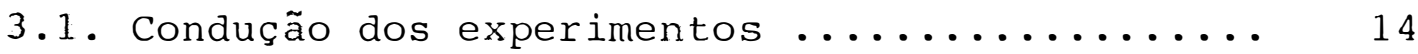

3.2. Análise estatistica dos dados ............. 19

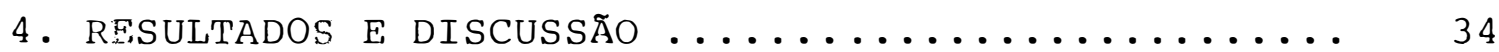

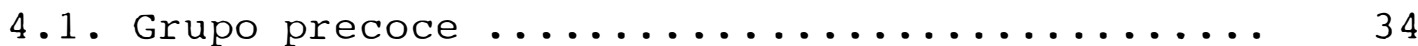

4.2. Grupo semi-precoce .................. 40

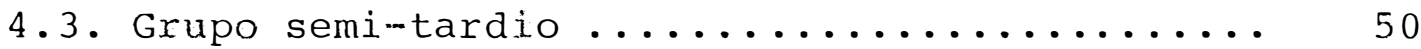

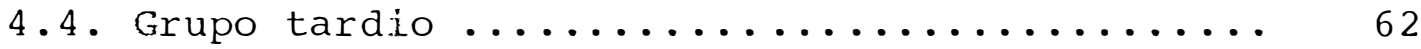

4.5. Estimativas de parâmetros genéticos nas gera-

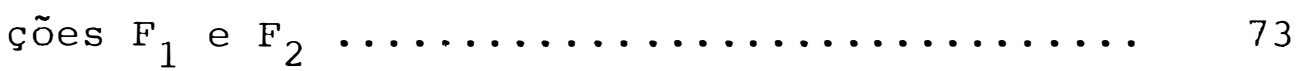

4.6. Sugestões para aprimorar a eficiência da avaliação do sistema radicular ............ 81

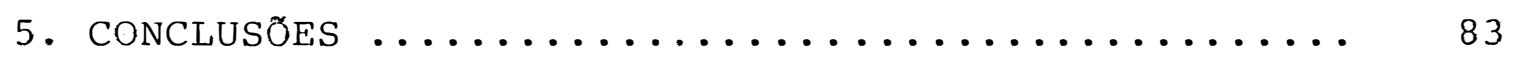

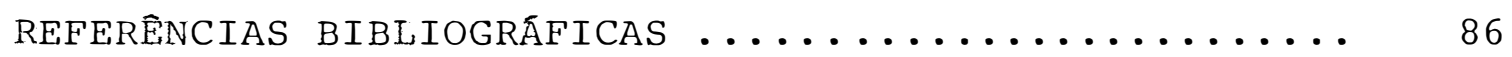

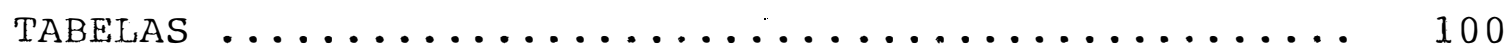

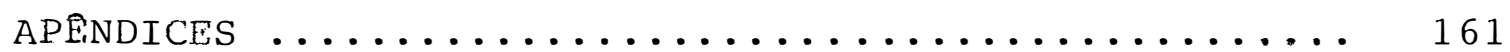




\title{
PARAMETROS GENETICOS RELACIONADOS AO SISTEMA RADICULAR E A PARTE AEREA DA SOJA [Glycine max (L.) Merril1]
}

\author{
Autor: CISODOALDO JOSE DA ANUNCIAÇÃO FILHO \\ Orientador: Prof. Dr. NATAL ANTONIO VELLO
}

RESUMO

Um sistema radicular bem desenvolvido deve possibilitar absorção eficiente de āgua e nutrientes, assegurando a formação de uma planta vigorosa e com alta produtividade, principalmente em condicões ambientais estressantes lalta temperatura, deficiência de āgua, salinidade, solos de baixa fertilidade e com altos niveis de elementos tóxicos tais como aluminio e manganês); também deve possibilitar fixação satisfatória da planta no solo, diminuindo os problemas com acamamento. Esta pesquisa teve por objetivos caracterizar o desenvolvimento do sistema radicular e correlacioná-lo com o desenvolvimento da parte aérea da soja. Lin uma primeira etapa, foram avaliados genótipos supostamente homozigóticos pertencentes a quatro grupos de maturação: 80 precoces, 62 semi-precoces, 44 semi-tardios e 16 tardios;este material foi avaliado para caracteres de plantas jovens (30 dias pós-semeaduras), cultivadas em telado sobre substrato de areia: peso seco de rałzes (PSR) e da parte aérea (PSA), comprimento da raiz principal (CRP) e da parte aérea (CPA); além disso, este material também foi avaliado para produtividade e acamamento de plantas maturas cultivadas em campo, em três locais da região de Piracicaba $\left(22^{\circ} 42^{\prime}\right.$ latitude sul, $47^{\circ} \delta^{\prime}$ longitude oeste, $540 \mathrm{~m}$ de altitude): ESALQ, Sertãozinho e Anhembi. Em uma segunda etapa, foram selecionados dois genótipos com sistema radicular bem desenvolvido 
(Paraná e Ivorá) e dois genótipos com sistema radicular pouco desenvolvido (Bragg e BR 6); foram realizados os cruzamen tos dialélicos entre estes quatro parentais, o avanço da geração $F_{1}$ para $F_{2}$ e a avaliação de plantas jovens cultivadas em telado sobre substrato de areia. Todas as etapas foram conduzidas pelo Setor de Genética Aplicada às Espécies Autógomas do Instituto de Genética da Escola Superior de AgricuI. tura "Luiz de Queiroz", ESALQ, da Universidade de são Paulo (USP). As seguintes conclusões foram obtidas: a. existiu va riabilidade genética tanto entre genótipos supostamente homo zigóticos quanto entre plantas da geração $\mathrm{F}_{2}$ para todos 'os caracteres; b. a quantidade de variabilidade genética foi di ferente nos quatro girupos de maturação; para PSR, a quantida de de variabilidade foi razoável apenas nos genótipos tardios; ro PSA existiu variabilidade razoável nos quatro grupos de maturação; O CRP mostrou gradiente decrescente de vam riabilidade dos genótipos precoces para os semi-precoces, se mi-tardios e tardios; O CPA exibiu nivel alto de variabilica de entre os genótipos precoces e niveis intermediários entre os genótipos semi-precoces, semi-tardios e tardios; a produtividade teve niveis razoáveis de variabilidade em todos os grupos de maturação e nos três locais, mas a magnitude de va riabilidade foi superior na ESALQ e em Sertãozinho e inferios em Anhembi; o acamamento mostrou altos níveis de variabilidade em todos os grupos de maturação e nos três locais ; c. interação genótipos $\mathrm{x}$ locais existiu apenas nos genótipos semi-precoces para produtividade e nos genótipos semi-precoces e semi-tardios para acamamento; d. a magnitude da hetero se variou com o caráter, com o cruzamento e com a geração $\left(F_{1}\right.$ ou $\left.F_{2}\right)$; os valores máximos foram: $30 \%\left(F_{1}\right)$ e $63 \%\left(F_{2}\right)$ pa ra PSR no cruzamento Ivorá $x \operatorname{BR} 6,23 \%\left(F_{1}\right.$ de Paranáx Bragg) e 38\% $\left(F_{2}\right.$ de Ivorá $x$ BR 6) para PSA; 3,4\% $\left(F_{2}\right.$ de paraná $x$ Bragg) e 21\% ( $F_{2}$ de Bragg $x$ BR 6) para CRP; $14 \%$ ( $_{1}$ de Paraná $x$ Bragg) e $39 \%\left(F_{2}\right.$ de Paranáx $x$ Ivorá) para CPA; $e$. as cor 
relaçöes genotipicas mostraram-se superiores às fenotipicas e as ambientais; correlações genotípicas altas para os genótipos homozigóticos dos quatro grupos de maturação e para a geração $\mathrm{F}_{2}$ ocorreram entre os caracteres PSR e PSA, PSR e CRP; os caracteres CRP e PSA exibiram correlações genotipica relativamente alta em todos os tipos lie genótipos, com excȩ̃ão semi-taraios; Os caracteres CRP e CPA mostraram correlações genotipicas relativamente altas apenas nos genótipos semi-tarios e na geração $\mathrm{F}_{2}$; as correlações genotipicas entre produtividade e acamamento foram muito variáveis (de -0,79 para genótipos semi-tardios em Sertãozinho até 0,99 para genótipos tardios na ESALQ); as correlações de caracteres de plantas jovens avaliadas no telado comcaracteres de plantas maturas avaliadas no campo foram próximas de zero, alcançando valor máximo de 0,25; f. a análise de Griffing rẹ velou diferenças na capacidade geral de combinação apenas para o caráter CPA; diferenças na capacidade especifica de combinação ocorreram nos caracteres PSR, CPA e PSA; Ivorá mostrou possuir a maioria dos genes para aumentar CRP e 'Paraná para aumentar CPA; os melhores niveis de complementação gênica ocorreram nos cruzamentos: Ivorá x BR 6 (PSR e PSA), Ivorá x Bragg (PSA), Bragg x BR 6 (CRP), Paraná x Ivorá (CPA); g. a análise de Hayman indicou aditividade em PSR e dominância gênica em PSA, CRP e CPA; as estimativas de herdabilidade no sentido restrito variaram com os caracteres: $0,18(\mathrm{CRP}), 0,28(\mathrm{PSA}), 0,36$ (CPA), 0,57 (PSR). 


\title{
GENETIC PARAMETERS RELATED TO ROOT AND AERIAL SYSTERS OF SOYBEAN [Glycine max (L.) Merrill] PLANT
}

\author{
Author: CLODOALDO JOSE DA ANUNCIAÇ̃̃O FILHO \\ Adviser: Prof. Dr. NATAL ANTONIO VELLO
}

\section{SUMMARY}

A highly developed root sýstem may provide efficient alusorption of water and nutrients, thus assuring the development of a vigorous and high seed yielding plant, especially undex environmental stress conditions (high temperature, water deficiency, salinity, low fertility associated with high level of toxid elements such as aluminum and manganese); it may also provide a satisfactory fixation of the plant in the soil and, thus, aecreasing the risk of lodging and falling. This research aimed to characterize the development of root system and to correlate root and aerial systems of soybeans. In a first step, young plants (30 days afters sowing), of 80 early, 62 semi-early, 44 semi-late and 16 late cultivars were grow evaluated on sand substrate in greenhouse for root dry weight (PSR), aerial part dry weight (PSA), main root length (CRP), aerial part (stem) length (CPA). Evaluation was made aldo in mature plants grow in field (three locations at Piracicaba region, $22^{\circ} 42^{\prime}$ South latitude, $47^{\circ} 33^{\prime}$. West longitude, $540 \mathrm{~m}$ altitude) for seed yield and lodging. In a secont step, two genotipes with more developod root system long (Paraná and Ivorá) and two less developed (Bragg and BR 6) were selected and crossed in a diallel design, $F_{1}$ generation was advanced to $\mathrm{F}_{2}$, and young plants were grow and evaluated in greenhouse. 
All steps were carried out by the Autogamous Species Laboratory, Institute of Genetics, Faculty of Agriculture "Luiz de Queiroz" (ESALQ), University of São Paulo (USP). The following conclusions were taken: a. there was genetic variability in all characters of homozygous lines and $\mathrm{F}_{2}$ plants; $\mathrm{l}$. the amount of genetic variability was different in four maturity groups: satisfactory level of variabiiity occurred For PSR only among late genotypes and for PSA in the four maturity groups; CRP exhibited a gradual ana decreasing variability level from early to semi-early, semi-late, and late genotypes; CPA presented high variability among early lines and intermediate level among semi-early, semi-late, and late lines; seed yield showed satisfactory lelvel of variability in four maturity groups and in three locations, but its magnitude was superior in ESALQ and Sertãozinho and inferior in Anhembi; lodging shawed high variability in all maturity groups and locations; $\mathbf{c}$. genotypes $x$ locations interaction occurred only in semi-carly lines for seed yield, and in semi-early and semi-late lines for lodging; $d$. the magnitude of heterosis varied for chacters, crosses, generations $\left(\mathrm{F}_{1}\right.$ and $\left.\mathrm{F}_{2}\right)$ and the maximum estimates were: $30 \%\left(\mathrm{~F}_{1}\right)$ and $63 \%\left(\mathrm{~F}_{2}\right)$. for PSR in the cross Ivorá x BR 6 ; 23\% ( $\mathrm{F}_{1}$, Paraná $\mathrm{x}$ Bragg) and 38\% ( $\mathrm{F}_{2}$ ' Ivorá $x$ BR 6) for PSA; 3.4\% ( $F_{1}$, Paraná $x$ Bragg) and 21\% (F ${ }_{2}$ ' Bragg $x$ BR 6) for CRP; $14 \%\left(F_{1}\right.$, Paraná $x$ Bragg) and 39\% ( $F_{2}$ ' Paraná $x$ Ivorá) for CPA; e. genotypic correlations were superior to phenotypic and environmental correlations; thigh genotypic correlations between PSR and PSA, PSR and CRP were found in cultivarars and experimental lines of allo four maturity groups; relatively high correlations occurred between CRP and PSA in all typesexcept for semi-late genotypes, between $\mathrm{CRP}$ and $\mathrm{CPA}$ only in semi-late and in $\mathrm{F}_{2}$ plants; genotypic correlation between seed yield and lodging varied from - 0.79 for semi-late genotypes grown in 
Sertãozinho to 0.99 for late genotypes grown in ESALQ; intra -class correlation between one character evaluetd in young plants in greenhouse and other character evaluated in mature plants in field were close to zero, reaching maximum value of 0.25 ; f. Griffing's analyses revealed differences in general combining ablitity only for cha; aifferences lu specific combining ability occurred in PSR, CPA, and PSA; Ivorá and Paraná were showed to have most genes for increasing CRP and CPA, respectively; best level of genic complementation occurred in Ivorá x BR 6 (PSR and PSA), Ivorá x Bragg (PSA), Bragg x BR 6 (CRP), Paraná x Ivorá $(C P A) ; g$. Hayman's analyses indicated additivity in PSR and dominance in PSA, CRP, and CPA; narrow sense heritabilities were 0.18 (CRP), 0.28 (PSA), 0.36 (CPA), 0.57 (PSR). 


\section{INTRODUÇÃO}

A soja [Glycine max (L.) Merril] é uma das principais espécies cultivadas que sustentam a economia brasileira, em função da ampla utilização na alimentação animal e na indústria de óleo comestível. Fila está se constituindo em fonte de proteína na alimentação humana, entrando na composição de carnes, leite e saladas.

E um fato de aceitação generalizada entre os pequisadores, que a produtividade de uma planta é função da profundidade e da densidade do seu sistema radicular, além de outros caracteres. Sistema radicular bem desenvolvido possiblita maior absorção de água e nutrientes pela planta, tornando-a mais tolerante à seca. Também, sendo profundo e ramificado, pode melhorar a arquitetura da planta, tornando-a menos suscetível ao acamamento. Eficiência na absorção da água e nutrientes e menor suscetibilidade ao acamamento podem levar à maior produtividade.

O sistema radicular da soja apresenta uma raiz principal (axial ou pivotante) desenvolvida a partir da radicula, com ramificações laterais numerosas e concentradas na parte superior da raiz principal. Embora a raiz principal possa alcançar $150 \mathrm{~cm}$ de profundidade, 86\% do peso seco do sistema radicular se localiza nos $15 \mathrm{~cm}$ superficiais do 
solo (MULLER, 1981). Genótipos de soja com sistema radicular bem desenvolvido, deverão ter adaptação ampla e estabilidade de produtividade de grãos. Entretanto, o número de pesquisas a respeito do sistema radicular e sobre suas relaçôes com a parte aérea, especialmente produtividade, é muito reduzido. Isto é devido, em grande parte, às dificuldades em se avaliar os caracteres do sistema radicular (BOHM et alii, 1977).

Eista pesquisa objetivou avaliar o sistema radicular e a produtividade de genótipos de soja, com a finalidade de estudar as relações entre os dois caracteres, além de se estimar parâmetros genéticos de interesse ao melhoramento.

Espera-se que as informações obtidas com a pesquisa realizada, sejam de grande utilidade para a escolha de parentais para futuros cruzamentos, visando obter genótipos com estabilidade fenotípica às variações ambientais, tais como deficiência hỉdrica, temperatura elevada, teores elevados de acidez e/ou alumínio, além de outros problemas do so10 . 


\section{REVISAO DE LITERATURA}

\subsection{Avaliação do sistema radicular (SR)}

O crescimento de uma planta é governado pela sintese de matéria orgânica nas partes aéreas verdes e pela absorção de nutrientes e água pelas raízes. Estes processos interagem na assimilação do đióxido de carbono, que é necessário para o crescimento da raiz e da parte aérea. Se a fixação de dióxido de carbono é baixa, as raízes crescem mal. Reciprocamente, se as raizes absorvem pequena quantidade de nutrientes e umidade, o crescimento é prejudicado. Sintomas observados acima do solo, podem ser causados por fatores do solo que afetam o desenvolvimento do sistema radicular e, conseqüentemente, a capacidade de absorção do sistema radicular (SCHUURMAN \& GOEDEWAAGEN, 1971).

A absorção de nutrientes e ãgua do solo são determinados pela aistribuição e extensão do sistema radicular. Dependendo do tipo de solo e disponibilidade de água as culturas necessitam de um sistema radicular bem desenvolvido, para explorar camadas mais profundas do solo. Por isso, elas tendem a ser mais resistentes aos períodos de escresses, que muitas vezes ocorrem durante o crescimento, e têm mais chances de alcançar alta produtividade. 
Tem sido pouco pesquisado o crescimento das raźies de soja em condições de campo, de maneira que pouco se conhece sobre a sua significāncia na determinação do crescimento da parte aérea. Condições ambientais e genéticas podem alterar as caracteristicas das raizes da soja. O conhecimento desses fatores seria importante no desenvolvimento de novas práticas culturais e de cultivares que resultariam em maiores produtividades de grãos (RAPER \& BARBER, 1970).

A maioria dos estudos quantitativos tem usado peso como um indicador, mas, é geralmente aceito que, absorção da raiz é mais diretamente relacionada à área da superfície ou comprimento total da porção em crescimento ativo, do que do peso de raiz. O principal problema em obter estimativa do comprimento da raiz é a quantidade de trabalho envolvido na remoção das raízes do solo e na medida do comprimento das raizes por volume de solo (REICOSKY et alii, 1970). KEY (1980) apresenta vários métodos para estudos de raízes; entretanto, estes métodos ou são de aifícil e trabalhosa execução, ou têm custos elevados, devido empregarem equipamentos sofisticados.

REICOSKY et alii (1970) fizeram comparação entre três métodos que estimam o comprimento do sistema radicular (SR) em soja. O primeiro método consistiu de medidas diretas feitas sobre amostras de raizes frescas. O segundo método, do opisômetro que, em essência, requer traçado sobre todo o comprimento de raiz amostrada. O terceiro método, desenvolvido por NEWMAN (1966), requer contagem do número de interseções entre raizes espalhadas ao acaso em uma malha de comprimento conhecido. O coeficiente de variação para médias de três estimativas, para cada método, mostrou que havia pouca diferença na precisão entre os métodos. 
MITCHELL \& RUSSEL (1971) verificaram que o sistema radicular da soja com 21 dias pós-semeadura, consiste de raízes laterais primárias e secundárias, que se desenvolvem cie um segnento da raiz principal. Diferenças no cres cimento e desenvolvimento de raizes ocorreram de acordo com o desenvolvimento vegetativo ou reprodutivo.

KASPAR et alii (1978) fizeram observações de raízes em laboratório, em sete cultivares de soja, para determinar a taxa que cada cultivar aumentar seu enraizamento em profundidade durante os estágios de desenvolvimento de cultura. Os cultivares diferiram significativamente em seu enraizamento de acordo com o estágio de desennvolvimento.

KASPAR et alii (1984) verificararn diferenças significativas na taxa de alongamento da raiz pivotante entre 105 cultivares de soja, desenvolvidos em tubos de plásticos em casa de vegetação. Quatro cultivares com taxas de alongamento vagarosas, foram desenvolvidos em parcelas de campo. Cultivares com taxas rápidas de alongamento obtiveram maior porcentagem de água abaixo de $120 \mathrm{~cm}$, do que aquelas com taxas vagarosas de alongamento.

MAYAKI et alii (1976) avaliaram a profundidade e a distribuição das raízes de soja, sob condições irrigada e não irrigada, em solo areno-argiloso. A cada amostragem das raizes, mediam-se a altura e o peso seco da planta, profundidade e distribuição das raízes e o indice de área foliar. As raizes de soja atingiram $160 \mathrm{~cm}$ de profundidade, tanto nas parcelas irrigadas quanto nas não irrigadas. Profundidade das raizes aumentou mais rapidamente do que a altura da planta. 
ANDREW (1966) comenta que em cultivo de campo, volume de raizes tem sido usado como indicador de crescimento para cortes de ramos herbáceos e como indicador do potencial de resistência ao tombamento. O autor argumenta que volume de raiz pode ser convertido para peso de raiz e, assim, determinar a relação parte aérea/parte radicular.

BROWN (1984) encontrou diferenças na densidade e distribuição de raízes com a idade da planta e que $50 \%$ do total de raízes distribuiu-se na camada de $50 \mathrm{~cm}$ do solo. Verificou ainda que as plantas de crescimento indeterminado desenvolveram maior porcentagem de raizes no sentido de profundidade (sob a fileira), enquanto que, as de crescimento de terminado desenvolveram mais raízes na área do sulco (mais lateralmente) e, que essa diferença foj mais pronunciada na fase reprodutiva do que na vegetativa.

\subsection{Herdabilidade}

A herdabilidade de um caráter métrico expressa a proporção da variância total que é atribuída ao efeito médio dos genes, e é este que determina o grau de semelhança entre indivíduos aparentados. Na análise genética de um caráter quantitativor a principal função da herdabilidade no sentido restrito é a predição, pois ela expressa a validade do valor fenotípico como um guia do valor genético (FALCONER, 1981). Geralmente, o melhorista fäz seleção com base no fenótipo e o sucesso na modificação dos caracteres da população pode ser predito através do conhecimento do grau de correspondència entre o valor fenotípico e o valor genético.

A herdabilidade não é um parâmetro populacio- 
nal estático, pois depende da precisão com que a variāncia ambiental é estimada. Cabe salientar também que um elevado valor da herdabilidade (por exemplo, 90\%) indica apenas que a variância genética apresenta um valor semelhante ao da variância fenotipica, isto é, a herdabilidade não reflete a magnitude das variâncias genética e fenotipica (ALLARD, 1971).

Além disso, a natureza das unidades de seleção (planta, parcela, média de várias parcelas, etc.) e erros de amostragem também influem grandemente na magnitude das estimativas de herdabilidade. Portanto, qualquer comparação significativa das estiamtivas obtidas em diferentes situações deve incluir uma avaliação cuidadosa dos métodos e materiais empregados (JOHNSON et alii, 1955a).

A herdabilidade de vários caracteres em soja tem sido estudada por diversos autores (GILLIOLI et alii, 1980; CAMPOS, 1979; TRAGNAGO, 1981; VERMA \& RAM, 1986; GREEN \& PINNELL, 1986; GREEN et alii, 1971; SING et alii, 1978; GREDER et alii, 1983; GUPTA et alii, 1980; LUEDDERS \& DICKERSON, 1977 e MIKU, 1980), cujos resultados apresentaram uma ampla variação e frequentemente não coincidiram, evidenciando que eles são dependentes da população estudada.

Vários autores (ANAND \& TORRIE, 1963; BARTLEY \& WEBER, 1952; CAMPOS; 1979; HANSON \& WEBER, 1962; JOHNSON et alii, 1955a; KOWN \& TORRIE, 1964; LUEDDERS et alii, 1973; MAHMUD \& KRAMER, 1951; MARTIN \& WILCOX, 1973; WEBER \& MOOR-THY, 1952 e RAJPUT et alii, 1987) verificaram que a altura da planta apresenta alta herdabilidade, geralmente superior à produtividade.

GUPTA et alii (1982) estimaram variâncias e 
coeficientes de variação fenotípica, genotípica e ambiental, e herdabilidade para vários caracteres da folha e da raiz de soja em três locais. Encontraram os seguintes valores para peso seco de raiz/planta: 0,08, 0,002 e 0,07, para variância fenotipica, genotipica e ambiental; 33,80, 5.24 e 33,40, para os coeficientes de variacão fenotipica, genotípica e ambiental, respectivamente; e $2,40 \%$ para a herbabilidade. baixo valor para herdabilidade obtido neste trabalho mostrou que peso seco de raiz/planta é um caráter altamente influenciado pelo ambiente.

MARIN (1980) cruzou cultivares de soja de a\}ta produtividade, plantas altas e com inserção da primeira vagem alta, com cultivares com caracteres opostos, obtendo altos valores para herdabilidade da altura da planta e número de sementes/planta. Produtividade, nümero de sementes/ planta e altura da primeira vagem foram influenciados pelo ambiente.

\subsection{Correlação entre caracteres}

Em estudos genéticos é conveniente distinguir duas causas de correlação entre caracteres: a genética e a ambiental. A correlação genética é provocada principalmente pela pleiotropia, embora ligações gênicas possam ser a causa de correlação transitória, principalmente em populações derivadas de cruzamentos entre linhagens divergentes. A correlação ambiental não é apenas a correlação dos desvios do ambiente, mas compreende a correlação conjunta de desvios de ambiente e desvios genéticos não aditivos (FALCONER, 1981; GRIFFING, 1956 ).

Segundo ROBINSON et alii (1951), muitos dos caracteres, de importāncia econômica são de herança complexa 
e podem envolver diversos outros caracteres. Portanto, a utilidade das correlações reside na possibilidade de estimar mudanças em dois ou mais caracteres simultaneamente.

Principalmente quando o caráter desejado é dificil de ser selecionado, pode-se, às vezes, obter progressos genéticos mais rápidos, fazendo-se a seleção de outros caracteres altamente correlacionados com o caráter principal. A eficiência da seleção indireta depende não somente das correlações, mas também das variâncias fenotípicas e genotípicas apresentadas pelos caracteres indicadores (JOHNSON et alii, 1955a).

O conhecimento das correlações entre caracteres de importāncia agronōmica na soja, pode facilitar a interpretação dos resultados obtidos e servir de base para uma programação mais eficiente dos trabalhos que se realizem no futuro (CARRASCO et alii, 1985).

WEISS et alii (1952) encontraram que correlações em soja variam significativamente entre anos, 1ocais e locais $x$ ano.

A correlação entre caracteres da parte aérea em soja tem sido amplamente estudada por diversos autores (CARRASCO et alii, 1985; TOLEDO \& KIIHL, 1982; RANA et alii, 1982; JOHNSON et alii, 1955b; KELLER et alii, 1978 e GUPTA et alii, 1980). Entretanto, correlações entre caracteres do sistema radicular e correlações relacionando o sistema radicular com a parte aérea tem sido muito pouco estudadas.

KASPAR et alii (1984) avaliaram a correlação entre taxas de alongamento da raiz principal e peso da semen te, em três rrupos de rnaturação da soja, cultivadas em casa de vege- 
tação e em campo; verificaram que não houve correlação entre esses caracteres $(r=-0,02)$.

WEBER \& MOORTHY (1952) estimaram todas as correlações possiveis entre sete caracteres de soja, encontrando correlações positivas entre florescimento e maturação, produtividade e dias para maturação, produtividade e altura da planta, produtividade e peso de semente.

\subsection{Ação gênica, variância genética e capacidade de com- binação}

De acordo com MOLL \& STUBER (1974), a maioria dos pesquisadores considera que a maior parte da variação genética é aditiva e que efeitos não-aditivos, embora presentes, são de pequena importância. Também KEMPTHORNE \& CURNOW (1961) comentam que a variância da capacidade geral de combinação é devido principalmente à variância genética aditiva.

Vários autores tem pesquisado parāmetros genéticos relacionados com produtividade e altura da planta. Em soja, CHAUDHARY(1986) analisou um dialelo parcial 7 x 7 , para produtividade e quatro componentes da produtividade,encontrando uma predominância de ação gênica não aditiva para todos os caracteres, exceto para altura de inserção da primeira vagem. A amplitude da capacidade geral de combinação e comportamento médio "per se" variaram com o ambiente.

LESHCHENKO \& MIKHAILOV (1977) encontraram valores altos para os efeitos da capacidade geral de combinação (CGC), para peso de grãos/planta, peso de cem sementes, nümero de sementes/planta e nümero de vagens/planta;en- 
contraram também valores baixos de CGC para altura da planta e localização das primeiras vagens.

KUNTA et alii (1985) avaliaram um dialelo parcial 4 x 4 e encontraram efeitos significativos da CGC para nümero de sementes/vagem, tamanho da semente e altura da planta, sugerindo a presença de variância aditiva na população, para esses caracteres. Efeitos significativos de produtividade e peso da planta sugerem a presença de variância genética não aditiva para esses dois caracteres. A interação Anos x CGC significativa para peso da planta e indice de colheita juntamente com interação Anos x CE.C não significativa, indicam que CEC foi mais estável sobre os anos do que CGC para estes caracteres.

$\bar{A}$ semelhança de KUNTA et alii (1985), PASCHAL \& WILCOX (1975) também avaliaram um dialelo parcial 12 x 12 - para verificar a magnitude da heterose, CGC e CEC em soja. Encontraram efeitos significativos para CGC para todos os caracteres; apenas tamanho da semente, tempo para maturação e altura da planta tiveram valores significativos de CE.C. LEFFEL \& WEISS (1958) e WEBER et alii (1970) estudaram a CGC e CEC. Os dois primeiros autores encontraram efeitos significativos da CGC para produtividade/planta, maturação, altura da planta e tamanho de sementes; efeitos significativos da CEC foram detectados para maturação, altura da planta e tamanho da semente. WEBER et alii (1970), também encontraram efeitos significativos da CGC e CEC para produção, maturação e altura da planta; estimaram a relação entre CGC e CE.C para esses caracteres, encontrando $1,63,6,15$ e 2,65, respectivamente.

Outros autores como TOLEDO \& KIIHL (1982) e SABBOUH \& EDWARDS (1985) estimaram parāmetros genéticos e 
efeitos das capacidades geral e específica de combinação em caracteres da parte aérea da planta de soja. Entretanto, nenhum estudo tem sido encontrado na literatura com respeito aos caracteres do sistema radicular

FALCONER (1981) empregou o termo coeficiente de determinação genotipica, para designar o quociente entre a variação genotípica e a variação fenotípica. Vârios autores (FONSECA, 1978; MONTEIRO, 1980; MARTINS \& VELLO, 1981) têm utilizado este termo para caracterizar a variabilidade de um conjunto fixo de. genótipos, tais como uma série de cultivares. Este conjunto fixo não representa uma população referência, de maneira que não satisfaz as exigências para emprego do coeficiente de herdabilidade. O coeficiente de determinação genotipica tem sido simbolizado por "b" e tem uma interpretação semelhante à do coeficiente de herdabilidade no sentido amplo, pois ambos estão relacionados com a variação genotípica. 


\section{MATERIAL E METODOS}

Foram utilizados genótipos de quatro grupos de maturação (precoce, semi-precoce, semi-tardio e tardio) da coleção de soja do Setor de Genética Aplicada às Espécies Autógamas (SGAEA) do Instituto de Genética da ESALQ/USP, compreendendo: 80 genótipos precoces (Tabela 1), 68 semi- precoces (Tabela 2), 51 semi-tardios (Tabela 3) e 22 tardios (Tabela 4). Estes 221 genótipos são provenientes da EMBRAPA/Centro Nacional de Pesquisa de Soja (CNPS), Instituto Agronômico de Campinas (IAC), Universidade F'ederal de Viçosa (UFV), Organização das Cooperativas do Estado do Paraná (OCEPAR), FT - Pesquisa e Sementes, Asian Vegetable Development Center, North Carolina State University, University of Flórida, Auburn Univesrity, University of Tennessee, University of Georgia e Clemson University.

Baseando-se nos resultados das avaliações do grupo de maturação precoce, foram escolhidos os quatro parentais contrastantes quanto ao comprimento médio da raiz principal (Paraná e Ivorá com 44 cm; Bragg e BR-6 com 21 e $29 \mathrm{~cm}$, respectivamente). Os quatro parentais selecionados foram cruzados dois a dois, obtendo-se um dialelo 4 x 4, com seis cruzamentos. As plantas $\mathrm{F}_{1}$ e $\mathrm{F}_{2}$ foram cultivadas em telado e avaliadas para caracteres do sistema radicular. Não foi avaliada a geração $F_{1}$ do cruzamento Bragg x BR-6. O nú- 
mero limitado de sementes obtidas nos cruzamentos não permitiu que o experimento fosse também realizado no campo; dessa maneira, não foram obtidos dados sobre produtividade e outros caracteres agronōmicos em plantas $F_{1}$ e $F_{2}$.

\subsection{Condução dos experimentos}

Para a realização desta pesquisa, foi planejada a condução de experimentos em dois ambientes: telado (casa de vegetação) e campo. As plantas do telado foram utilizadas para avaliação do sistema radicular, enquanto que as plantas do campo foram avaliadas para caracteres agronômicos. Inicialmente foram avaliados 221 genótipos homozigóticos (cultivares e linhagens experimentais) pertencentes a quatro grupos de maturação (Tabelas 1 a 4), em telado e campo. Posteriormente, foram avaliados quatro parentais (contrastantes no sistema radicular), cinco cruzamentos $\mathrm{F}_{1}$ e seis cruzamentos em $\mathrm{F}_{2}$.

Tanto os experimentos de telado quanto os experimentos de campo foram delineados em blocos ao acaso com tratamentos estratificados em conjuntos (grupos) experimentais dentro de repetições com testemunhas comuns (VELLO, 1985; FARIAS Neto, 1987). Esta estratificação foi necessäria devido ao número relativamente grande de genótipo de cada grupo de maturação. Conforme considerações de FARIAS NETO (1987), a estratificação dos tratamentos tem vantagens em relação ao "lattice" (reticulados quadrados): organização experimental e análise mais simples, principalmente se ocorrerem parcelas perdidas. O delineamento utilizado difere do delineamento em que os tratamentos são divididos em subexperimentos (grupos) com testemunhas comuns (GOMES, 1987). 
O nümero de conjuntos experimentais foi variável em cada grupo de maturação, de acordo com o número de genótipos: quatro (precoce e semi-precoce), três (semi-tardio), dois (tardio). Foram utilizadas testemunhas comuns dentro de cada conjunto. Nos experimentos de campo, incluiram-se três testemunhas comuns, pertencentes ao mesmo grupo de maturação dos genótipos em teste. Nos experimentos de telado, empregaram-se seis testemunhas comuns, sendo três pertencentes ao mesmo grupo de maturação dos genótipos em teste e uma representante de cada um dos três grupos de maturação restantes.

\subsubsection{Experimentos em telado}

Os experimentos em telado foram conduzidos em Piracicaba (SGAEA, Instituto de Genética, ESALQ, USP).

Para os grupos precoce e semi-precoce, usaram-se cinco repetições, sendo as plantas avaliadas aos 30 dias pós-semeadura; para os grupos semi-tardio e tardio, utilizaram-se seis repetições, sendo três avaliadas aos 30 dias e as outras três aos 45 dias pós-semeadura.

Os experimentos foram instalados nas seguintes datas:

a. grupo precoce: 20.11.84 (primeira repetição);

b. grupo semi-precoce: 11.01 .85 (primeira repetição) ;

c. grupo semi-tardio: 16.11 .85 (primeira repetição) ;

d. grupo tardio: 05.02.86 (primeira repetição).

O experimento contendo os genótipos obtidos por cruzamentos $\left(F_{i s}^{\prime}\right.$ e $\left.F_{2 s}^{\prime}\right)$, os parentais e testemunhas co- 
muns foi instalado em 15.01.1987.

Com a finalidade de escalonar as avaliações experimentais, as repetições seguintes (além da primeira) foram instaladas gradativamente, sempre defazando uma semana da repetição anterior. Este procedimento foi comum em todos os experimentos.

Foram utilizados sacos plásticos com dimensões de $50 \mathrm{~cm}$ de comprimento por $16 \mathrm{~cm}$ de diâmetro, contendo areia lavada de rio como substrato. Esses sacos, tinham capacidade para $5.500 \mathrm{ml}$ (ou $9 \mathrm{~kg}$ de areia). Foram semeadas oito sementes/saco, desbastando-se para quatro plāntulas, três dias após a emergência. No caso de genótipos $\mathrm{F}_{2}$ 's e $\mathrm{F}_{1}$ 's' devido ao reduzido nümero de sementes, semeou-se apenas uma semente/saco. Aplicou-se $50 \mathrm{ml}$ de solução nutritiva completa de SARRUGE (1970) (Apēndice 1) por saco, de quatro em quatro dias e irrigou-se em dias alternados, com ãgua de torneira. Não foi usada água destilada porque ela desequilibra a solução nutritiva, atraindo para si os íons da solução (HAAG, 1984) ${ }^{1}$.

\section{Foram feitas as seguintes avaliações:}

a. comprimento da raiz principal ou pivotante (CRP), em cm/ planta:

b. comprimento da parte aërea (CPA), em cm/planta;

C. peso seco de raízes (peso total das raízes) (PSR), em g/ planta;

d. peso seco da parte aérea (PSA), em g/planta.

I HAAG, H.P. (Escola Superior de Agricultura "Luiz de Queiroz"/JSP, Piracicaba, SP) . Comunicação Pessoal, 1984. 
Para realizar essas avaliações, suspendeu-se a irrigação e a adição de solução nutritiva, uma semana antes, para que a areia pudesse ficar seca e, assim desprecnder-se totalmente do sistema radicular. Por ocasião da avaliação, efetuou-se um corte longitudinal no saco plástico, estando o mesmo apoiado numa peneira de malha fina para reter a(s) raiz(es) que eventualmente se desprendesse(m) da matriz axial. Portanto, a peneira só deixava passar a areia, retendo todo o sistema radicular da planta. Após retirar toda a areia, efetuou-se a separação das raízes e parte aérea, com um corte à altura do coleto, por intermédio de uma tesoura de poda.

Desta forma, o comprimento da raiz principal representou a distāncia entre a região seccionada (coleto) e a extremidade da raiz principal. Da mesma maneira, o comprimento da parte aérea correspondeu à distāncia entre a região (coleto) e a inserção do ültimo nó (ūltima folha trifoliada). Tanto a parte aërea quanto todo o sistema radicular foram colocados em sacos de papel, devidamente identificados com o tratamento correspondente e colocados em estufa com circulação forçada de ar, a $65^{\circ} \mathrm{C}$, durante 72 horas. Após a retirada da estufa, o material foi deixado esfriar durante 24 horas em ambiente aberto, para entrar em equilibrio com a umidade ambiental, obtendo-se a seguir os pesos secos de raízes e da parte aérea.

\subsubsection{Experimentos em campo}

Os experimentos em campo referentes aos quatro grupos de maturação foram conduzidos em três locais da região de Piracicaba: 
a. ESALQ - área experimental do Instituto de Genética, com solo série Luiz de Queiroz, de textura argilosa (RANzANI et alii, 1966).

b. Sertãozinho - com solo série Sertãozinho, de textura média (RANZANI et alii, 1966).

c. Anhembi - solo de textura love, caracterizado por areia quartzoza.

Esses locais situam-se a $22^{\circ} 42^{\prime} 30$ ' de latitü de sul e 47 $38^{\prime}$ de longitude Oeste, com uma altitude média de $540 \mathrm{~m}$. As anälises química do solo dos trēs locais, encontram-se no Apêndice 2 .

A instalação dos experimentos envolvendo os genótipos dos quatro grupos de maturação, foi realizada em outubro/84 e as avaliações foram efetuadas em fevereiro/março/85. As médias mensais de temperatura, precipitação pluvial e umidade relativa encontram-se no Apēndice 3.

Foram utilizadas duas repetições por experimento e por local. A parcela foi constituida de quatro fileiras de $5 \mathrm{~m}$ de comprimento, espaçadas de $0,60 \mathrm{~m}$. A área útil da parcela foi constituida pelos $4 \mathrm{~m}$ centrais das duas fileiras intermediārias da parcela, perfazendo uma área de $4,8 \mathrm{~m}^{2}(4 \times 1,2)$.

Para o plantio, o terreno foi sulcado à profundidade aproximada de $10 \mathrm{~cm}$. O adubo foi distribuído dentro do sulco, na base de 25 gramas/m da mistura 0-30-1 . A seguir o adubo foi coberto por uma camada de cerca de $5 \mathrm{~cm}$ de terra, sobre a qual fora distribuidas 30 sementes/m. As sementes foram cobertas com uma camada de 3 a $5 \mathrm{~cm}$ de terra. Após a emergência foi feito o desbaste, deixandorse um estande de 15 a 20 plantas/m. Por ocasião do plantio, as sementes forạm inoculadas com inoculante comercial Bradyrhizo- 
bium japonicum, de marca Nitral (gentileza do Dr. Sólon Cordeiro de Araújo.

Foram feitas avaliações da produtividade (peso de grãos em $\mathrm{kg} / \mathrm{hal}$ e do acamamento, empregando-se uma escala subjetiva de notas, variando de um a cinco, na qual a nota um correspondeu às parcelas com 1008 de plantas eretas e a nota cinco foi atribuída às parcelas com $100 \%$ de plantas completamente prostradas.

\subsection{Análise estatística dos dados}

\subsubsection{Gemótipos homozigóticos}

Para os experimentos conduzidos no telado, a parcela experimental correspondeu a um saco plástico com quatro plantas. As análises de variância foram feitas a partir das médias das quatro plantas de uma parcela.

Os dados relativos ao acamamento, por se tratarem de notas ( 1 a 5 ), foram transformados em $\sqrt{x+1}$, conforme recomendações de STEEL \& TORRIE (1980b), para obter aproximação à distribuição normal.

Efetuaram-se as análises de variância (ANAVA) conjuntas (blocos casualizados) dos grupos de maturação semi-tardio e tardio, para os caracteres avaliados em telado, dos dados das testemunhas comuns, para verificar a existēncia ou não do efeito de épocas de avaliação (30 e 45 dias) e a interação testemunhas $x$ épocas (Tabela 5). O modelo matemático usado foi o seguinte:

$$
\mathrm{Y}_{i j k}=\mu+\mathrm{T}_{i}+\left(B / E_{j k}+E_{k}+(T E)_{i k}+e_{(i j k)},\right.
$$

onde: 


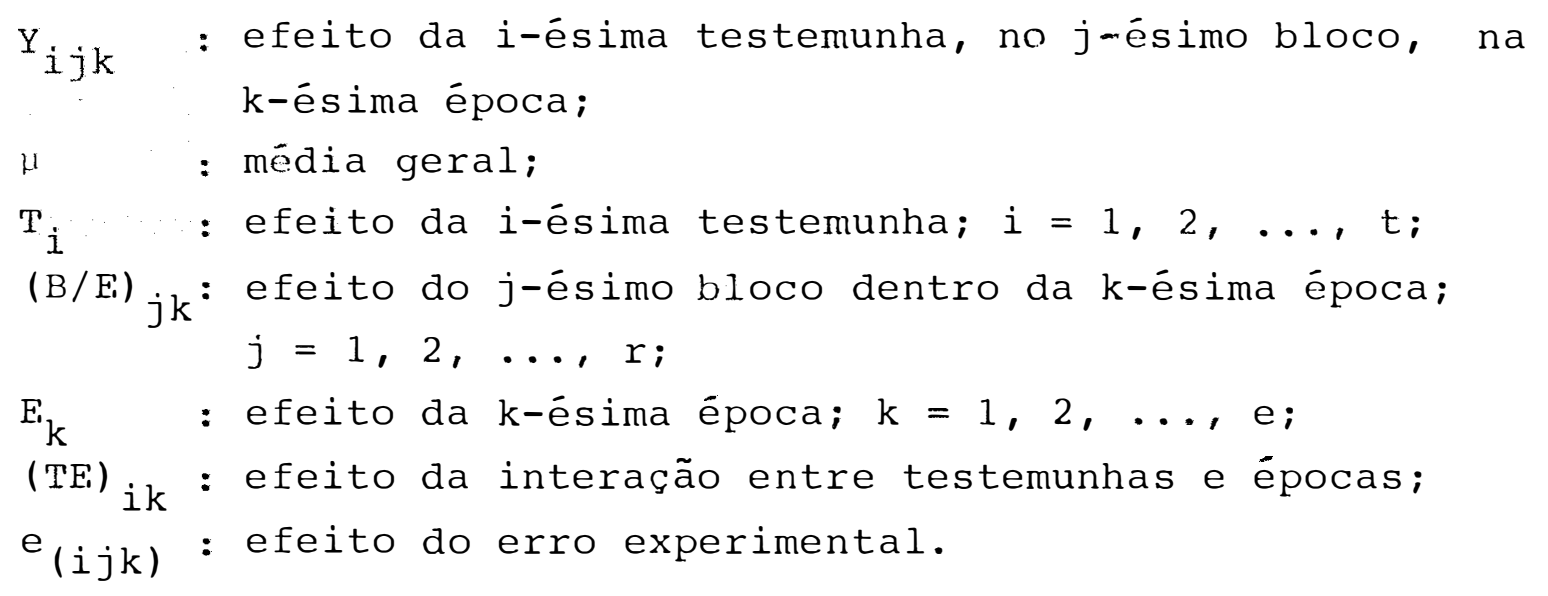

$$
\text { Os efeitos }\left(B / E_{1}\right)_{j k} e_{(i j k)} \text { foram considera- }
$$
dos independentes e normalmente distribuidos com médias zero e variâncias $\sigma_{\mathrm{B} / \mathrm{E}}^{2}$ e $\sigma_{\mathrm{e}}^{2}$, respectivamente. Os fatores épocas e testemunhas foram considerados fixos.

Efetuou-se ainda, a análise da variância (ANAVA), para es quatro grupos de maturação de soja, empregando apenas as testemunhas comuns, tanto para os caracteres avaliados em telado, como para os de campo, objetivando verificar a existēncia ou não do efeito de conjuntos e da interação testemunhas $x$ conjuntos. O esquema da ANAVA com a indicação do teste "F" encontra-se na Tabela 6. O modelo matemático usado foi o seguinte:

$$
\left.Y_{i j k}=\mu+T_{i}+B_{j}+C_{k}+B C_{j k}+C T_{i k}+B T_{i j}+e_{(i j k}\right)^{\prime}
$$

onde:

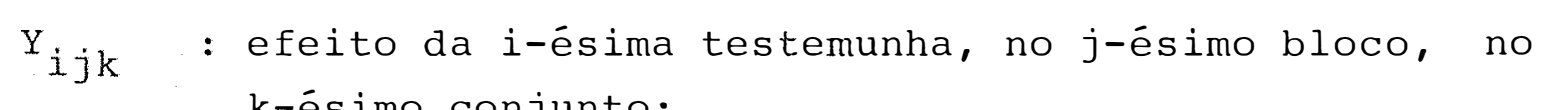
k-ésimo conjunto;

$\mu \quad$ : média geral;

$\mathrm{T}_{\mathbf{i}} \quad$ : efeito da i-ésima testemunha;

$B_{j} \quad$ : efeito do j-ésimo bloco;

$\mathrm{C}_{\mathrm{k}} \quad$ : efeito do k-ésimo conjunto;

$\mathrm{BC}_{j k}$ : efeito da interação do j-ésimo bloco com o k-ésimo conjunto; 
$\mathrm{CT}_{i k}$ : efeito da interação do k-ésimo conjunto com a i-ésima testemunha; $\mathrm{BT}_{i j}:$ efeito da interação do j-ésimo bloco com a i-ésima
testemunha;

$e_{(i j k)}$ : efeito do erro experimental.

$i=1,2, \ldots, t ; j=1,2, \ldots, r ; k=1,2, \ldots, c$.

Os efeitos $B_{j}, e_{(i j k)}$ foram considerados independentes e normalmente distribuidos, com médias zero e variāncias $\sigma_{\mathrm{B}}^{2}$ e $\sigma_{\mathrm{e}}^{2}$, respectivamente. O fator testemunha foi considerado fixo.

O nümero de graus de liberdade (GL) do denominador do teste "F" para testemunhas (n'), foi obtido atravẻs das recomendações de SATTERTHWAITE (1946), que consiste em:

$$
n^{\prime}=\frac{\left(Q_{2}+Q_{3}-Q_{1}\right)^{2}}{\left(Q_{2}^{2} / n_{2}\right)+\left(Q_{3}^{2} / n_{3}\right)+\left(Q_{1}^{2} / n_{1}\right)}
$$

onde:

$\mathrm{n}_{1}, \mathrm{n}_{2}$ e $\mathrm{n}_{3}$ são os GL correspondentes aos respectivos quadrados médios $\left(Q_{i}\right)$.

$\mathrm{Na}$ presença de uma interação entre um efeito fixo e outro aleatório, é mais apropriado multiplicar-se a variāncia da interação por um fator de correção dado pela relação entre o nümero de dados do efeito fixo e seu GL. No presente caso, apenas testemunhas tem efeito fixo. Como varia de 1 a $t$, o fator de ajuste é $t /(t-1)$ (STEFL \& TORRIE, 1980 a). 
para cada local é mostrada na Tabela 7. Para efeito desta análise adotou-se o seguinte modelo matemático:

$$
Y_{n j}=\mu+G_{n}+B_{j}+e_{(n j)}
$$

onde:

$Y_{n j} \quad$ : efeito do n-ésimo genótipo no j-ésimo bloco;

$\mu \quad$ : média geral;

$\mathrm{G}_{\mathrm{n}} \quad$ : efeito do n-ésimo genótipo;

$B_{j} \quad$ : efeito do j-ésimo bloco;

$e_{(n j)}$ : efeito do erro exeprimental;

$\mathrm{n} \quad: 1,2, \ldots, \mathrm{g}$.

Os efeitos $B_{j}$ e e $(n j)$ foram considerados independentes e normalmente distribuidos com médias zero e vaxiāncias $\sigma_{\mathrm{B}}^{2}$ e $\sigma_{\mathrm{e}}^{2}$, respectivamente. O fator genótipos foi considerado fixo.

Foi realizada ainda a análise de variāncia conjunta envolvendo os três locais para verificar os efeitos de locais (L) e da interação genótipos x locais (Tabela 8). O modelo matemático usado foi o seguinte:

$$
\mathrm{Y}_{n m j}=\mu+L_{m}+(B / L)_{j m}+G_{n}+(G L)_{n m}+e_{(n m j)}
$$

onde:

$Y_{n m j}$ : efeito do n-ésimo genótipo, no m-ésimo local, no j-ésimo bloco;

$\mu \quad$ : média geral;

$(B / L)_{j m}$ : efeito do j-ésimo bloco dentro do m-ésimo local;

$\mathrm{G}_{\mathrm{n}} \quad$ : efeito do n-ésimo genótipo;

(GL) $_{\mathrm{nm}}$ : efeito da interação do n-ésimo genótipo com o m-ésimo local;

$e_{(n m j)}:$ residuo médio. 
$\mathrm{n}=1,2, \ldots, \mathrm{g} ; \mathrm{m}=1,2, \ldots, \ell ; j=1,2, \ldots, \mathrm{r}$.

o efeito de e (nmj) foi considerado independente e normalmente distribuido com média zero e variância $\mathrm{o}^{2}$. Os fatores genótipos e locais foram considerados fixos.

\section{a. Análise de covariância}

Os caracteres avaliados neste estudo foram pareados dois a dois. Em cada grupo de.dois, foram somados os valores destes caracteres, em cada parcela, obtendo-se novos valores que foram utilizados para análise de variância. Esta análise é efetuada da mesma forma como o é para caracteres individuais (KEMPTHORNE, 1973).

$$
\begin{aligned}
& \text { Assumindo que } Z=X+Y, \quad \text { então: } \\
& V(Z)=V(X)+V(Y)+2 \operatorname{CoV}(X, Y)
\end{aligned}
$$

assim:

$$
\operatorname{COV}(X, Y)=\frac{V(Z)-V(X)-V(Y)}{2}
$$

Por este princípio geral, do quadrado médio da análise da soma dos caracteres (Z), subtrairam-se os respectivos quadrados médios dos caracteres X e Y e o resultado foi dividido por dois, dando os produtos médios correspondentes.

O esquema da análise de covariância é o apresentado na Tabela 9, cujas esperanças dos produtos médios foram obtidos, segundo MODE \& ROBINSON (1959). 


\section{b. Coeficientes de correlação}

Foram estimados coeficientes de correlação dentro de cada ambiente (telado e campo) entre os caracteres avaliados, empregando-se as seguintes fórmulas, oriundas da Tabela 9 :

b.1. Coeficiente de correlação fenotipica $\left(\mathrm{r}_{F}\right)$

$$
\hat{r}_{F}=\operatorname{COV}_{E}(X, Y) /\left[V_{F}(X) \cdot V_{F}(X)\right]^{1 / 2},
$$

onde:

$\operatorname{COV}(\mathrm{X}, \mathrm{Y})=$ produto médio de tratamentos para os caracteres $\mathrm{X}$ e $\mathrm{Y}$;

$V(X)$ e $V(Y)=$ quadrados médios de tratamentos, para os caracteres $\mathrm{X}$ e $\mathrm{Y}$, respectivamente.

b.2. Coeficiente de correlação genotipica $\left(\mathrm{r}_{\mathrm{G}}\right)$

$$
\hat{r}_{G}=\operatorname{CoV}_{G}(X, Y) /\left[V_{G}(X) \cdot V_{G}(X)\right]^{1 / 2}
$$

onde:

$\operatorname{COV}_{G}(X, Y)=$ covariância genotípica para os caracteres $X$ e $Y$, obtida por:

$$
\operatorname{COV}_{G}(X, Y)=\left[\operatorname{Cov}_{F}(X, Y)-\operatorname{COV}_{E}(X, Y)\right] / r
$$

sendo que:

$\operatorname{Cov}_{\mathrm{e}}(\mathrm{X}, \mathrm{Y})=$ produto médio do erro para os caracteres $\mathrm{X}$ e $\mathrm{Y}$;

$r \quad=$ repetições ou blocos.

$\mathrm{V}_{\mathrm{G}}(\mathrm{X}) \quad=$ variância genotípica do caráter $\mathrm{x}$, obtida por: 


$$
V_{G}(x)=\left[V_{F}(x)-V_{E}(x)\right] / r,
$$

onde:

$\mathrm{V}_{\mathrm{E}_{1}}(\mathrm{X})$ = quadrado médio do erro para o caráter $\mathrm{X}$.

$\mathrm{V}_{\mathrm{G}}(\mathrm{Y})=$ variância genotípica do caráter $\mathrm{Y}$, obtida por:

$$
V_{G}(Y)=\left[V_{F}(Y)-V_{E}(Y)\right] / r
$$

onde:

$\mathrm{V}_{\mathrm{E}_{1}}(\mathrm{Y})$ = quadrado médio do erro para o caráter $\mathrm{Y}$.

b.3. Coeficiente de correlação ambiental

$$
\hat{x}_{E}=\operatorname{COV}_{E_{i}}(X, Y) /\left[V_{E^{\prime}}(X) \cdot V_{E^{\prime}}(Y)\right]^{1 / 2}
$$

\subsubsection{Coeficientes de determinação genotipica}

$$
\text { O coeficiente de determinação genotípica }
$$

foi estimado para todos os caracteres avaliados, através da fórmula:

$$
\mathrm{b}=\frac{\left(Q_{2}-Q_{1}\right) / x}{\left(Q_{2}-Q_{1}\right) / x+\left(Q_{1} / x\right)}
$$

onde,

$Q_{1}$ e $Q_{2}$ : são os respectivos quadrados médios do residuo e de tratamentos da análise de variância de cada caráter;

r = corresponde ao nûmero de repetições ou blocos. 


\subsubsection{Coeficientes de correlação intra-classe}

Estimaram-se correlações intra-classes relacionando os caracteres avaliados em telado com os avaliados em campo. Assim, para um dado par de caracteres obtiveram-se 30 valores de correlação, combinando duas a duas as cinco repetições em telado com as seis repetições em campo. A média dos 30 ( 5 × 6 ) valores correspondeu à estimativa da correlação intra-classe para cada par de caracteres. Utilizou-se a seguinte fórmula (STEEL \& TORRIE, 1980a):

$$
s=\frac{\operatorname{cov}\left(Y_{1 j}, Y_{2 j},\right)}{\sqrt{\sigma_{1 j}^{2} \cdot \sigma_{2 j}^{2}}}
$$

onde:

$\operatorname{COV}\left(Y_{1 j}, Y_{2 j}\right)=$ covariância entre os caracteres um e dois nas repetições $j$ e j';

$\sigma_{\frac{1}{2} j}^{2}=$ variância do caráter um na repetição $j$;

$\sigma_{2 j}{ }^{\prime}{ }^{\prime}=$ variância do caráter dois na repetição j'.

\subsubsection{Genótipos parentais, $F_{1 ' s}$ e $F_{2}$ 's}

Foi empregado o teste de Bartlett (STEEL \& TORRIE, 1980b), para verificar a homogeneidade de variâncias, no desdobramento das somas de quadrados do residuo das anälises de variāncias.

Nesse grupo de materiais foram estimados os seguintes parâmetros: heterose e herdabilidade no sentido amplo. Foram feitas também as análises dialélicas de GRIFFING (1956) e de HAYMAN (1954). 


\section{a. Heterose}

Foi verificada a significāncia da heterose através do teste $t$ :

$$
t=\frac{h-0}{\sqrt{V\left(\widehat{\Psi}_{i}\right)}}
$$

Onde, apra os $\mathrm{F}_{1} \mathbf{s}_{\mathrm{s}}$ :

$h=$ heterose $=P_{i}$

$$
\begin{aligned}
& \hat{\mathrm{P}}_{i}=\overline{\mathrm{F}}_{1}-\left(\overline{\mathrm{P}}_{1}+\overline{\mathrm{P}}_{2}\right) / 2 \text { ou } \\
& \hat{\mathrm{P}}_{i}=\overline{\mathrm{F}}_{1}-\left(1 / 2 \overline{\mathrm{P}}_{1}-1 / 2 \overline{\mathrm{P}}_{2}\right) \\
& V\left(\bar{y}_{1}\right)=\left[\frac{\mathrm{C}_{\mathrm{F}_{1}}^{2}}{\mathrm{r}_{\mathrm{F}_{1}}}+\frac{\mathrm{C}_{\mathrm{P}_{1}}^{2}}{\mathrm{r}_{\mathrm{P}_{1}}}+\frac{\mathrm{C}_{\mathrm{P}_{2}}}{\mathrm{r}_{\mathrm{P}_{2}}}\right) \mathrm{s}^{2},
\end{aligned}
$$

sendo:

$\overline{\mathrm{P}}_{1}, \overline{\mathrm{P}}_{2}, \overline{\mathrm{F}}_{1}, \overline{\mathrm{F}}_{2}$ : média do caráter no parental 1, parental 2,

$$
\mathrm{F}_{1} \text { e } \mathrm{F}_{2} \text {; }
$$

$C$ : coeficiente relativo ao genótipo;

$r$ : número de repetições relativo ao genótipo;

$\mathrm{s}^{2}$ : quadrado médio do resíduo da ANAVA, onde entram os parentais, os $F_{1}$ 's' os $F_{2}$ 's $e$ as testemunhas.

Portanto temos:

$$
V\left(\hat{Y}_{i}\right)=\left(\frac{1^{2}}{3}+\frac{(1 / 2)^{2}}{3}+\frac{(1 / 2)^{2}}{3}\right) s^{2}=\frac{1}{2} s^{2}
$$


Assim:

$$
t=\frac{h-0}{(1 / 2) \mathrm{s}^{2}} \quad \operatorname{com} 40 \mathrm{GL}
$$

Para os $\mathrm{F}_{2}$ 's' temos:

$$
\begin{aligned}
& \mathrm{P}_{i}=2\left[\overline{\mathrm{F}}_{2}-\frac{\overline{\mathrm{P}}_{1}+\overline{\mathrm{P}}_{2}}{2}\right]=2 \overline{\mathrm{F}}_{2}-\overline{\mathrm{P}}_{1}-\overline{\mathrm{P}}_{2} \\
& V\left(\rho_{i}\right)=\left[\frac{C_{F_{2}}^{2}}{r_{F_{2}}}+\frac{C_{P_{1}}^{2}}{r_{P_{1}}}+\frac{C_{P_{2}}^{2}}{r_{P_{2}}}\right] s^{2}= \\
& =\left(\frac{4}{3}+\frac{1}{3}+\frac{1}{3}\right) s^{2}=\frac{6}{3} s^{2}=2 s^{2}
\end{aligned}
$$

assim,

$$
t=\frac{h-0}{\sqrt{2 \mathrm{~s}^{2}}}, \quad \operatorname{com} 40 \mathrm{GL} .
$$

Foram estimadas as heteroses dos $\mathrm{F}_{2}$ 's' a semelhança dos $\mathrm{F}_{1}{ }^{\prime} \mathrm{s}^{\prime}$ tendo-se o cuidado de multiplicar por dois, os resultados obtidos.

\section{b. Herdabilidade no sentido amplo $\left[h^{2}(A)\right]$}

As estimativas de herdabilidade no sentido amplo foram feitas através dos seguintes cálculos:

$$
h^{2}(A)_{i}=\frac{V_{G}}{V_{d F_{2 i}}}
$$


onde:

$\begin{aligned} h^{2}(A)_{1}: & \text { herdabilidade no sentido amplo do i-ésimo cruzamento } \\ & \text { em } \mathrm{F}_{2} ;\end{aligned}$

$V_{G} \quad$ : estimativa da variāncia genotipica;

$\mathrm{V}_{\mathrm{dF}_{2 i}}$ : variāncia dentro do i-ésimo cruzamento em $\mathrm{F}_{2}$.

Sendo que:

$$
\mathrm{V}_{\mathrm{G}}=\mathrm{V}_{\mathrm{dF}}-\mathrm{VE}
$$

onde:

$\mathrm{V}_{\mathrm{E}_{\mathrm{t}}}=$ estimativa da variància ambiental.

$$
V_{E}=\frac{\left(V_{d} P_{i} \times G L P_{i}\right)+\left(V_{d} P_{j} \times G L P_{j}\right)}{G L P_{i}+G L P_{j}}
$$

ou

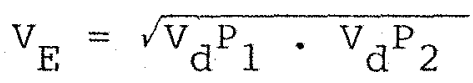

onde:

$\mathrm{V}_{\mathrm{d}}\left(\mathrm{P}_{i}\right.$ ou $\left.\mathrm{P}_{j}\right)$ : variāncia dentro do i-ésimo ou j-ésimo parental;

GL $\left(P_{i}\right.$ ou $\left.P_{j}\right)$ : graus de liberdade do i-ésimo ou j-ésimo parental.

Empregou-se a fórmula (1), que é uma média ponderada das variāncias dentro dos parentais, quando eles não possuíam os mesmos números de graus de liberdade (GL); a förmula (2), que é uma média geométrica, foi usada quando os parentais apresentaram o mesmo nümero de graus de liberdade, conforme DESTRO et alii (1987).

Na obtenção das estimativas das variāncias ou 
quadrados médios dentro de $\mathrm{F}_{2}$ ( $\mathrm{V}_{\mathrm{d}}$ ou QMD), empregou-se a mesma metodologia das fórmulas (1) e (2), ou seja, as variāncias entre plantas dentro de repetições foram ponderadas pelos nümeros de graus de liberdade das diferentes repetições quando os números de graus de liberdade variaram entre as repetições ou, utilizou-se a média geométrica das variāncias entre plantas dentro de repetições, quando o número de graus de liberdade foi constante em todas as repetições.

Estimaram-se os erros associados às herdabilidades, através da fórmula seguinte, deduzida a partir dos procedimentos delineados por VELLO \& VENCOVSKY (1974):

$$
\begin{aligned}
\left.s_{\left[h_{(A)}^{2}\right]}\right] & =\frac{1}{Q_{3}}-\sqrt{\frac{1}{2}\left[\frac{Q_{1}^{2}}{n_{1}+1}+\frac{Q_{2}^{2}}{n_{2}+1}+\frac{4 Q_{3}^{2}}{n_{3}+1}+\frac{1}{n_{3}+1}\left(2 Q_{3}-Q_{1}-Q_{2}\right)^{2}-\right.} \\
& \left.+\frac{4}{n_{3}+1}\left(2 Q_{3}-Q_{1}-Q_{2} Q_{3}\right)\right]
\end{aligned}
$$

onde:

$Q_{1}, Q_{2}$ e $Q_{3}$ : variāncias ou quadrados médios dentro dos parentais 1 e 2 e de $F_{2}$, respectivamente, para um determinado cruzamento;

$n_{1}, n_{2}$ e $n_{3}$ : números de graus de liberdade das variâncias dentro dos parentais 1 e 2 e de $F_{2}$, respectivamente, para um determinado cruzamento.

\section{c. Análise dialélica de GRIFFInG}

Foi utilizado o método 2, modelo misto B, apresentado por GRIFFING (1956). Com quatro parentais empregados, tem-se $6 \mathrm{~F}_{2}{ }^{\prime} \mathrm{s}$ e 10 tratamentos em cada repetição. U- 
saram-se três repetições.

O mëtodo 2 inclui os parentais e o conjunto dos $n(n-1) / 2$ hibridos $F_{1 ' s}$ ou das progênies $F_{2 ' s}$ sem incluir os reciprocos. No modelo misto, os efeitos de tratamentos são fixos e os de blocos e erro experimental são aleatórios.

O uso do modelo misto B decorre da escolha deliberada dos genótipos parentais. Portanto, todas as inferências e conclusões possiveis devem ser restritas ao material genético empregado neste estudo.'

Considerou-se o modelo estatistico de blocos casualizados, ou seja:

$$
Y_{i j k}=\mu+T_{i j}+B_{k}+e_{i j k} \quad \text { em que: }
$$

i, $j=1,2, \ldots, n(n=4)$ (parentais);

$k=1,2, \ldots, r(n=3)($ blocos $)$;

$Y_{i j k}$ : observações do i $x$ j-ésimo genótipo no k-ésimo bloco;

$\mu$ : média geral da população;

$\mathrm{T}_{i j}$ : efeito do $\mathrm{i} \times$ j-ésimo genótipo (tratamento);

$\mathrm{B}_{\mathrm{k}}$ : efeito do k-ésimo bloco;

$e_{i j k}$ : efeito do erro experimental.

$$
e_{i j k}=\operatorname{NID}\left(0, \sigma_{e}^{2}\right)
$$

NID = normal e independentemente distribuido.

Na Tabela 10 é apresentado o esquema da análise de variância, de quatro caracteres avaliados em telado, onde:

$\mathrm{V}_{\mathrm{T}}=$ medida da variação genética dos tratamentos. 


$$
V_{T}=\sum_{i j}\left(T_{i j}-\bar{T}\right)^{2} /(g-1)
$$

Na análise da capacidade de combinação,

○ efeito de tratamentos é considerado em termos de efeitos para capacidade geral $\left(g_{i}\right)$ e especifica $\left(s_{i j}\right)$ de combinação, de forma que:

$$
T_{i j}=g_{i}+g_{j}+s_{i j}
$$

sendo

$g_{i}=$ efeito da capacidade geral de combinação do i-ésimo parental;

$g_{j}=$ efeito da capacidade geral de combinação do j-ésimo parental;

$s_{i j}=$ efeito da capacidade especifica de combinação para o cruzamento do parental de ordem i com o de ordem $j$.

\section{d. Análise dialélica de HAYMAN}

A metodologia da análise dialélica de HAYMAN (1958) e estimativa dos parâmetros genéticos foi apresentada detalhadamente por MIRANDA (1987) e FREIRE FILHO (1988).

Nesta análise foram estimados os seguintes parâmetros de maior interesse ao melhoramento:

$\overline{\mathrm{D}}=$ componente genético referente à ação gênica aditiva;

$\hat{\mathrm{F}}=$ frequência relativa dos alelos dominantes e recessivos na população parental; se $F$ for positivo, indica uma predominância de alelos dominantes, e se for negativo, predominância de alelos aditivos;

$\hat{\mathrm{H}}_{1}=$ componente genético referente à ação gênica dominante (ou componente não aditivo); 
$\left(\mathrm{H}_{2} / \mathrm{D}\right)^{1 / 2}=$ grau médio de dominância;

$h_{(r)}=$ herdabilidade no sentido restrito.

Os erros padrões associados aos parâmetros foram calculados conforme FERREIRA (1985), utilizando os multiplicadores especificos (para $\mathrm{n}=4$ ), para o multiplicador comum:

$$
s^{2}=1 / 2\left[\operatorname{Var}\left(w_{r}-v_{r}\right)\right]
$$

onde:

$W_{r}=$ covariância entre os parentais e a descendēncia;

$\mathrm{v}_{\mathrm{r}}=$ variância dos parentais. 


\section{RESUltadOS E DISCUSSÃo}

Os dados foram analisados e agora discutidos individualmente para cada grupo de maturação.

\subsection{Grupo precoce}

Neste grupo de maturação foram analisados apenas os caracteres avaliados em telado. Não foi possível avaliar os caracteres nos experimentos de campo porque ocorreram chuvas intensivas durante a maturação da maioria dos genōtipos precoces, provocando deterioração de vagens e germinação de sementes dentro das vagens.

A análise de variāncia das testemunhas para os caracteres avaliados em telado, considerando conjuntos de tratamentos, é apresentada na Tabela 11. Os efeitos de conjuntos (C) e de interação conjuntos e testemunhas (C $\mathrm{x} T$ ), não foram significativos para todos os caracteres, o que permitiu conduzir as anālises em blocos casualizados.

Na Tabela 12 estão apresentadas as análises de variāncia dos quatro caracteres do sistema radicular. O caráter peso seco de raízes (PSR) mostrou tendēncia para coeficientess de variação experimental (CV) altos $(25,6 \%$ nas 
testemunhas, Tabela 11; 28,7응 nos genótipos testados, Tabela 12.). Os outros três caracteres, peso seco da parte aérea (PSA), comprimento da raiz principal (CRP) e da parte aérea (CPA) apresentaram CV's médios tanto nas testemunhas quanto nos genótipos. Apenas PSA apresentou CV relativamente maior nas testemunhas. Foram detectadas diferenças significativas entre os genótipos nos quatro caracteres do sistema radicular (Tabela 12). As médias dos 80 genótipos precoces e das testemunhas estão representadas na Tabela 13 .

\section{a. Peso seco de raizes (PSR)}

A amplitude de variação foi de 0,17 (Forrest) a 0,43 (Ivorá) gramas/planta. Além de Ivorá, os genótipos FT 81-2112, Hil1, Hood e FT 81-1878, também apresentaram um comportamento médio em torno de 0,40 g/planta (Tabela 13). Pode-se ainda constatar que, aproximadamente 47 응 dos genótipos, foi superior à média das testemunhas $(0,32 \mathrm{~g} / \mathrm{planta})$.

Corro maior PSR pocle significar maior volume, decorrente, provavelmente, de um maior nümero de raizes primárias e secundárias, o que possivelmente torna tais genótipos mais eficientes em absorção de nutrientes do solo e, con sequentemente talvez mais produtivos, além de se fixarem methor ao solo, reduzindo o indice de tombamento e os problerias relacionados a esse caráter. Esses resultados podem ser relacionados com os de TIAN (1986) estudando nove cultivares de soja, constatou diferenças significativas entre os números de raízes primárias e secundārias, além da relação peso/ comprimento foi maior nas raizes primárias do que nas secundárias.

O baixo valor obtido para o coeficiente de determinaç̃̃o genotípica (Tabela 14), sugere que PSR é bas- 
tante influenciado pelo ambiente, caracterizando uma certa dificuldade em se modificar esse carāter por meio de seleção. Considerações semelhantes também foram feitas por FONSECA (1978), MONTEIRO (1980) e MARTINS \& VELO (1981, com outras espécies.

\section{b. Peso seco da parte aérea (PSA)}

Pode-se verificar na Tabela 12 que ocorreram diferenças altamente significativas entre os genótipos; tal resultado era esperado, tendo em vista o elevado número de tratamentos $(80)$ e as origens diversas dos mesmos.

Na Tabela 13, observa-se que a amplitude de variação foi de $0,44 \mathrm{~g} / \mathrm{planta}$ (Bragg e Forrest) a 0,92 g/ planta (Pampeira). Outros genótipos também tiveram um comportamento médio bastante satisfatório para PSA: Campos Gerais, Cocker 156, FT 80-86, FT 81-1799, FT 81-1823, FT 81-1878, FT 81-2044, FT 81-2050, FT 81-2153, Hill e Lancaster.

Ainda na Tabela 13, verifica-se que $51 \%$ dos genōtipos tiveram comportamento médio superior às testemunhas $(0,66 \mathrm{~g} / \mathrm{planta})$.

A pequena magnitude das estimativas do coeficiente de determinação genotipica (b =0,394, Tabela 14) e do coeficiente de variação genotípica $\left(\mathrm{CV}_{\mathrm{G}}=7,79 \%\right.$, Tabela 12) indicaram a existēncia de pequena variabilidade genética em PSA. Deve ser difícil alterar O PSA através de métodos simples de melhoramento. 


\section{c. Comprimento da raiz principal (CRP)}

Para esse caráter também foram detectadas diferenças altamente significativas entre tratamentos (Tabela 12). A amplitude de variação foi de 21,1 (Bragg) a 45,6 (IAs 2 - escura) cm/planta (Tabela 13). Além da IAs 2 - escura, outros genótipos também tiveram um excelente comportamento relativo: FT 81-1799, FT 81-1802, FT 81-1835, FT 81-1865 , FT 81-2044, FT 81-2177, Hood, SOC 823 .

Pode-se constatar que 48\% dos genótipos apresentaram comportamento superior à média das testemunhas. Esses resultados se aproximam dos de KASPAR et alii (1984), onde os autores avaliaram diariamente (a partir de 35 dias pós-semeadura) as taxas de alongamento da raiz principal no solo (comprimento) de dois grupos de soja: um com rápido alongamento e o outro alongamento vagaroso. Encontraram variação na taxa de crescimento diário de 3,5 a 5,3 cm/dia. Maior comprimento da raiz principal e, em consequēncia, das raízes primárias e secundárias, logicamente acarretará planta mais vigorosa e com menor indice (ou ausēncia) de tombamento.

A variância genotípica $\left(V_{G}=10,682\right)$, o coeficiente de determinação genotípica $(b=0,569$, Tabela 14) e o coeficiente de variação genotípica $\left(\mathrm{CV}_{\mathrm{G}}=8,26 \%\right.$ Tabela 12) indicam maior variabilidade e menor influência ambiental no CRP do que em PSR e PSA; este fato talvez possibilite que CRP possa ser modificado com maior facilidade através de programas de seleção. 


\section{d. Comprimento da parte aérea (CPA)}

Os resultados da Tabela 12 mostram que houve diferenças altamente significativas entre os genótipos para CPA. Na Tabela 13 verifica-se que a amplitude foi 36,9 (Bragg) a 68,9 (PI 54610) cm/planta. Entre os 80 genótipos avaliados, além de PI 54610, outros também tiveram bom desenvolvimento, para a época de avaliação $(30$ dias pós-semeadura), entre eles: FT 81-1797, FT 81-2050, FT 81-2133, Fr' 81-2153, FT 81-2154, FT 81-2177, FT 81-2690. Fm relação à média das testemunhas, $68 \%$ dos genótipos teve um comportamento superior.

Sem dūvida, a amplitude de variação observada no desenvolvimento da parte aérea dos genótipos precoces tem um componente genético de grande magnitude, conforme indicado pelos valores de variância genotípica $\left(27,03: \mathrm{cm}^{2}\right.$, Tabela 14); coeficiente de variação genotípica $(10,33 \%$, Tabela 12) e coeficiente de determinação genotipica $(b=0,812$, Tabela 14). Este último parâmetro foi muito superior às estimativas obtidas para os outros três caracteres (PSR, PSA, CRP), indicando que O CPA deve oferecer maiores facilidades para resposta à seleção.

BURTON (1952) comenta que o coeficiente de variação genotípica $\left(\mathrm{CV}_{\mathrm{G}}\right)$ junto com a herdabilidade, dá uma melhor visão da quantidade de ganho a ser esperado com a seleção. Entretanto, a utilização de "b", bem como da herdabilidade no sentido amplo, deve ser feita com certa cautela, pois ambos medem a variação genética total e nem todos os seus componentes são aproveitáveis na seleção.

O valor obtido para "b" de 0,812, é bem próximo ao encontrado por FARIAS NETO (1987), para altura da 
planta em cultivos reunidos $(0,849)$.

\section{e. Correlação genotipica $\left(r_{G}\right)$, fenotipica $\left(r_{F}\right)$ e ambiental $\left(r_{A}\right)$}

Geralmente, os melhoristas fazem seleção simultânea para vārios caracteres que podem ser ou não correlacionados entre si. Ao empregar a correlação, como auxilio a um programa de seleção, deve-se considerar que a associacão diretamente observada entre caracteres representa a correlação entre valores fenotípicos. Esse tipo de correlação pode conduzir a erros, uma vez que em sua constituição, intervèm uma fração genética e outra ambiental (FALCONER, 1981). Assim, torna-se importante verificar qual porção genotipica está contida na correlação fenotípica, para que o fenótipo possa refletir adequadamente o genótipo. Nesse enfoque, o valor prático das correlações dependerá do seu sinal e da sua magnitude.

As estimativas dos coeficientes de correlação genotipica, fenotipica e ambiental, entre os quatro caracteres, são apresentadas na Tabela 14. Os coeficientes de correlação genotípicos foram positivos e superiores em magnitude aos coeficientes de correlação fenotipicos. Em vista disto, pode-se concluir que há uma tendência de maior contribuição dos fatores genéticos que dos ambientais, nas coxrelações entre os caracteres avaliados.

Dos seis coeficientes de correlação genotípica, três foram de alta magnitude $\left(r_{G}\right.$ maior que 0,5$)$. Normalmente, os melhoristas de plantas consideram 0,5 como sendo um valor médio a alto de coeficiente de correlação. A significância das correlações tem sido considerada secundária 
em relação à magnitude da própria estimativa porque não há definição segura do número de graus de liberdade para se testarem as correlações genotipicas. Foram obtidas correlacões genotípicas altas e positivas entre os caracteres PSR e PSA $(0,748), \operatorname{PSR}$ e CRP $(0,978), \operatorname{CRP}$ e PSA $(0,714)$. Correlações genotipicas positivas mas inferiores a 0,5 ocorreram entre os caracteres: CPA e PSA $(0,332)$, CPA e CRP $(0,312)$. Esses resultados concordam com aqueles obtidos por CARRASCO \& GONZALEZ (1985) e FARIAS NETO (1987). Caracteres com correlação genotípica muito baixa (p. ex. 0,0652 entre PSR e CPA) não devem possuir associação e possivelmente foram selecionados independentemente durante a evolução da soja.

\subsection{Grupo semi-precoce}

Os genótipos 63 (BR 7), 64 (União), 65 (BR 1), 66 (OC 79-11), 67 (Pickett 71 - North Carolina) e 68 (Planaltol, originalmente apresentados na relação de materiais, foram eliminados por não germinarem em condições de telado e por apresentarem falhas nas parcelas de campo (estande muito baixo). Assim, este grupo de maturação passou a ter 62 genótipos.

As análises de variância das testemunhas para os caracteres avaliados nos experimentos conduzidos no telado e em campo, considerando conjuntos de tratamentos, encontram-se nas Tabelas 15 e 16, respectivamente. Os efeitos de conjunto (C) e da interação conjuntos e testemunhas $\left(\begin{array}{lll}C & \mathrm{x} & \mathrm{T}\end{array}\right)$ não apresentaram resultados significativos para todos os caracteres estudados, possibilitando conduzir as análises em blocos casualizados. De maneira geral, os coeficientes de variação podem ser classificados como médios, com exceção do PSA, com CV $=23$ 응. 


\subsubsection{Experimento em telado}

A Tabela 17 mostra a análise de variāncia e os coeficientes de variação experimental e genotípica dos quatro caracteres dos 62 genótipos semi-precoces cultivados em telado.

\section{a. Peso seco de raizes (PSR)}

Apesar do coeficiente de variação experimental relativamente alto $(\mathrm{CV}=27 \%)$, foram detectadas diferenças altamente significativas entre os genótipos.

O comportamento médios dos genötipos avaliados encontra-se na Tabela 18. Pode-se verificar que a amplitude de variação foi de 0,17 (BR 1 - fosca e Soc 81-119), a 0,37 (FT 1), g/planta. Além de FT 1, outros genótipos também apresentaram valores altos de PSR: FT 2, FT 7, FT 81-2706, OC 79-20 e Pérola, com valores iguais ou superiores a $30 \mathrm{~g} / \mathrm{planta}$. Constata-se ainda, que 53응 dos genótipos teve um comportamento superior à média das testemunhas $(0,24 \mathrm{~g} /$ planta).

Pelos valores do coeficiente de determinação genotipica $(b=0,438$, Tabela 22$)$ e do coeficiente de variação genotipica $\left(\mathrm{CV}_{\mathrm{G}}=10,78 \%\right.$, Tabela 17$)$, constata-se que a variabilidade genética não é alta no PSR, confirmando os resultados anteriormente discutidos para o grupo precoce.

b. Peso seco da parte aérea (PSA) 
tre os genótipos semi-precoces em PSA (Tabela 17). O comportamento médio dos genótipos (Tabela 18) demonstrou que a amplitude de variação foi de 0,39 (BR 1-fosca) a 0,75 (Bossier), g/planta. Além de Bossier, alguns genótipos também tiveram bom desenvolvimento da parte aérea, com valores de $\mathrm{PSA} \geqq 70 \mathrm{~g} / \mathrm{planta}$ : Centennial, FT 81-2706, Kirby e SOC 81-76. Além disso, 48\% dos genótipos apresentou comportamento médio superior à média das testemunhas $(0,57 \mathrm{~g} / \mathrm{planta})$.

Os resultados obtidos na Tabela 22 para

0 coeficiente de determinação genotipica $(b=0,615)$ e o coeficiente de variação genotipica $\left(\mathrm{CV}_{\mathrm{G}}=10,78 \%\right.$, Tabela mostraram valores maiores do que as estimativas obtidas para os genótipos precoces. Aparentemente a magnitude da variabilidade genética para PSA é um pouco maior no grupo semi-precoce do que no precoce.

\section{c. Comprimento da raiz principal (CRP)}

Os resultados apresentados na Tabela 17 mostram que existem diferenças altamente significativas entre os genótipos semi-tardios para CRP. Na Tabela 18, pode-se constatar que a amplitude de variação foi de 32,5 (SOC 81-119) a 48,5 (BR 4) cm/planta. Outros genótipos também mostraram bom desenvolvimento da raiz principal, com resultados superiores a 44 g/planta: Centennial, Década, FT 2, FT 81-2163, FT 81-2706, GO 81-8102, GO 81-8106, GO 81-11075 e OC 79-5. Ainda, $48 \%$ dos genótipos apresentaram comportamento médio superior à média das testemunhas $(40,9 \mathrm{~cm} / \mathrm{planta})$.

Os valores obtidos para os coeficientes de variação genotípica $(0,40 \%$, na tabela 17) e de determinação genotipica $(0,403$, Tabela 22), indicaram que CRP tem varia- 
bilidade genética muito baixa entre os genótipos semi-precoces. Estes resultados bastante diferente daqueles discutidos para o grupo precoce, onde CRP mostrou niveis relativamente altos de variabilidade genética.

\section{d. Comprimento da parte aérea (CPA)}

Ocorreram diferenças altamente significativas entre os genótipos semi-precoces (Tabela 17). A amplitude de variação foi de 42,1 (OC 79-84) a 61. (Bossier) cm/planta. Outros genótipos também tiveram bom desenvolvimento da parte aérea ( $\$ 55 \mathrm{~cm} / \mathrm{planta}):$ BR 4, BR 80-6935, CEPS 7716, Dourados, FT 5, FT 81-2136, FT 81-2706 e Kirby. Verifica-se ainda que, cerca de $44 \%$ dos genótipos foram superiores a média das testemunhas $(49,4 \mathrm{~cm} / \mathrm{planta}$, Tabela 18). Esses resultados estão de acordo com ALA \& GAMOLIN (1987), que encontraram uma variação na altura da planta na maturação de 47,1 a $62,5 \mathrm{~cm}$, em Glycine max, e de 94,5 a $162 \mathrm{~cm}$, em G. soja. EGLY et alii (1985), FOLEY et alii (1986) e wILCOX et alii (1984), também encontraram variações na altura da planta.

Os valores obtidos para os coeficientes de determinação $(0,577$, Tabela 22$)$ e de variação genotípica (7,34\%, Tabela 17), indicaram a existēncia de quantidade razoável de variabilidade genética entre os genótipos semi- precoces para CPA. Resultados semelhantes foram obtidos no grupo precoce. 


\subsubsection{Experimentos em campo}

\section{a. Anhembi}

Na Tabela 19 verifica-se que houve diferenças altamente significativas entre os genótipos semi-precoces para os caracteres produtividade de grãos e acamamento. Essas diferenças eram esperadas em virtude, não só do elevado nümero de genótipos, mas, principalmente, devido a origem desses genótipos. Os coeficientes de variação podem ser classificados como médios apra produtividade $(20,0 \%)$ e baixo para acamamento $(6,1 \%)$.

O comportamento médio dos genótipos para os caracteres produção e acamamento nos três locais encontra-se na Tabela 20 .

Para a produtividade, em Anhembi, a variação foi de $437,5 \%(T N 82-273)$ a 2312,5 (Cobb) kg/ha. Os genótipos BR $1(2083,3 \mathrm{~kg} / \mathrm{ha}), \operatorname{Cobb}(2312,5 \mathrm{~kg} / \mathrm{ha}), \quad$ Dourados $(2000 \mathrm{~kg} / \mathrm{ha}), \mathrm{FT} 7(2020,8 \mathrm{~kg} / \mathrm{ha}), \mathrm{FT} 9(2062,5 \mathrm{~kg} / \mathrm{ha}), \mathrm{FT}$ 81-2706 (2145,8 kg/ha), IAC 1, SOC 81-76 e SOC 81-105 (2291,7 $\mathrm{kf} / \mathrm{ha})$, tiveram produtividade média, igual ou superior à média do Estado de São Paulo $(2000 \mathrm{~kg} / \mathrm{ha})$. Em relação à média das testemunhas $(1750 \mathrm{~kg} / \mathrm{ha}), 32 \%$ dos genótipos foram superiores. Variabilidades semelhantes foram obtidas por FOLEY et alii (1986) e WILCOX et alii (1984).

Com relação ao acamamento, caráter este que influi diretamente na produtividade, a amplitude de variação, em termos de nota, foi de 1 (para planta ereta $=1,41$, em dado transformado) a 3,5 (plantas com forte inclinação = 2,12, em dado transformado) (Tabela 20). De uma maneira ge- 
ral, houve um bom comportamento para esse caráter, tendo em vista que a grande maioria (77\%), eram plantas eretas com o mesmo comportamento das testemunhas. FOLEY et alii (1986) e WILCOX et alii (1984) também encontraram resultados semelhantes para as familias de cruzamentos avaliados em vários locais.

Os coeficientes de determinação genotipica (b) para produtividade $(b=0,698)$ e acamamento $(b=0,872)$, na Tabela 23, são valores relativamente altos, indicando que esses caracteres podem ser mais facilmente alterados por seleção, principalmente o acamamento.

\section{b. Sertãozinho}

Houve diferenças altamente significativas entre os genótipos semi-precoces para produtividade e acamamento. O coeficiente de variação foi médio para produtividade $(15,0 \%)$ e baixo para acamamento $(6,4 \%)$, demonstrando bom controle experimental (Tabela 19). Para produtividade O CV foi inferior ao de Anhembi ( $\mathrm{CV}=20 \%)$ e para acamamento foi superior ao de Anhembi ( $\mathrm{CV}=6,1 \%)$.

A amplitude de variação da produtividade foi de $562,5 \mathrm{~kg} / \mathrm{ha}(\mathrm{TN} 82-273$ ) a $3250 \mathrm{~kg} / \mathrm{ha}$ (SOC 81-124) (Tabela 20). No geral, a produtividade dos genótipos foi de boa a excelente, comparada com a média de são Paulo ( $\pm 2000 \mathrm{~kg} / \mathrm{ha})$. Em relação à média das testemunhas, apenas $19 \%$ dos genótipos tiveram um comportamento superior.

Para acamamento, a amplitude de variação em termos de nota foi de 1 (planta ereta $=1,41$, em dados transformados) a 4,24 (planta com forte inclinação $=2,29$, em da- 
dos transformados). Assim, 53\% dos genótipos apresentaram-se eretos com comportamento superior à média das testemunhas (Tabela 20). WILCOX et alii (1984), obtiveram resultados similares na amplitude de variação na descendência do cruzamento entre Amsoy x Beeson x PI 68788 .

Os coeficientes de determinação genotípica para produtividade $(\mathrm{b}=0,621)$ e acamamento $(\mathrm{b}=0,914)$ (Tabela 23) foram relativamente altos e semelhantes aos valores de $\mathbf{b}$ obtidos no exeprimento de Anhembi.

\section{c. ESALQ}

Na Tabela 19, verifica-se que não houve diferença significativa entre genótipos para o caráter produtividade e que ocorreram diferenças altamente significativas para acamamento. O coeficiente de variação foi alto para produtividade $(23,7 \%)$ e médio para acamamento $(12,4 \%)$.

Apesar de não haver sido detectadas diferenças estatisticamente significativas entre os genótipos semi- precoces para produtividade, provavelmente devido ao elevado coeficiente de variação, a amplitude de variação foi de 1417 kg/ha para CNS a $3229 \mathrm{~kg} / \mathrm{ha}$ para Jackson. A produtividade foi muito boa, apresentando 69 \% dos genótipos com valores superiores à média de são Paulo (em torno de 2000 kg/ha). Além disso, 17ㅇo dos genótipos foram superiores à média de produtividade das testemunhas $(2562 \mathrm{~kg} / \mathrm{ha})$. Desses, Davis $(2771 \mathrm{~kg} / \mathrm{ha})$, FT 2 (3042 kg/ha), FT 79-3408 e Jackson (3229 $\mathrm{kg} / \mathrm{ha})$, Kirby $(2792 \mathrm{~kg} / \mathrm{ha})$, foram os que apresentaram maiores médias (Tabela 20). Esta grande amplitude de produtividade tem sido observada em soja. Por exemplo, WILCOX \& SEDIYAMA (1981) observaram amplitudes de 1651 a 4305 kg/ha en- 
tre linhagens de crescimento determinado e de 2235 a 4611 $\mathrm{kg} / \mathrm{ha}$ entre linhagens de crescimento indeterminado.

O valor do coeficiente de determinação genotipica $(b=0,295$, Tabela 23), bem como do coeficiente de variação genotípica $\left(\mathrm{CV}_{\mathrm{G}}=11 \%\right)$ para produtividade (Tabela 19) mostraram que este caráter sofre bastante influência do ambiente, como ocorre comumente em caracteres quantitativos. Esses resultados se assemelham com os de CAMACHO (1977).

O acamamento apresentou variação, em termos de notas, de 1 (planta ereta, equivalente a 1,41 em dado transformado) a 5 (planta prostrada, correspondente a 2,45 em dado transformado) (Tabela 20). Assim, $61 \%$ dos genótipos arpesentaram plantas eretas, e 72 응 com menos plantas acamadas que a média das testemunhas $(1,51$, em dados transformados). Esses resultados estão de acordo com os de WILCOX \& SEDIYAMA (1981), que encontraram variação para acamamento,em notas de 1,0 a 1,7 , apra as 1inhagens de porte determinado e 1,0 a 4,3 , para as linhagens de porte indeterminado. WEBER \& FEHR (1966), encontraram uma perda de produtividade de $34,5 \mathrm{~kg} / \mathrm{ha}(1,3 \%)$, atribuida ao acamamento; com o controle do acamamento ocorreu aumento de $395 \mathrm{~kg} / \mathrm{ha}(13 \mathrm{q})$ na produtividade.

\section{d. Anälise conjunta}

A análise conjunta para produtividade e acamamento, apresentada na Tabela 21 , revela que houve efeitos altamente significativos de locais apra os dois caracteres; a interação entre genótipos e locais também resultou significativa. Isto mostra que, para ambos os caracteres, os genótipos sẹmi-precoces comportaram-se diferentemente de acor- 
do com o local, o que éra esperado, tendo em vista as diferenças marcantes em tipos de solos entre ESALQ, Sertãozinho e Anhembi; este último local possue um tipo de solo semelhante aos encontrados nos cerrados, textura e propriedades quimicas bem diferentes dos dois primeiros (RANZANI et alii, 1966; SILVA, 1980).

De uma maneira geral, em Anhembi, a produtividade foi menor do que a dos outros dois locais. Isto provavelmente foi devido à menor fertilidade do solo e às quantidades relativamente altas de elementos tóxicos (alumínio e manganês) existentes naquele solo. Estes fatores devem ter limitado o crescimento das plantas, provocando em consequência menor produtividade e menor acamamento ('Tabela 20). Em Sertãozinho e na ESALQ, principalmente neste último local, - acamamento foi muito mais pronunciado, em função, provavelmente, da boa fertilidade do solo; plantas ficaram mais altas e, consequentemente, mais sujeitas ao acamamento, como é o caso de Santa Maria (nota 5 ou 2,45, em dados transformados), o que contribuiu para a produtividade relativamente baixa deste genótipo. Esses resultados são semelhantes aos de COOPER (1971), WEBER \& FEHR (1966) e WILCOX \& SEDIYAMA (1981) .

\subsubsection{Correlações genotipicas $\left(r_{G}\right)$, fenotipica $\left(r_{F}\right)$ e ambiental $\left(r_{E}\right)$ e correlações intra-classe entre caracteres avaliados no telado em can- po}

Para os genótipos semi-precoces, as estimativas dos coeficientes de correlação genotipica, fenotípica e ambiental, entre os quatro caracteres, avaliados em condições de telado, encontram-se na Tabela 22 ; entre os dois ca- 
racteres avaliados em campo, as correlações estão na Tabela 23.

Analisando a Tabela 22 , verifica-se que as correlações genotipicas foram todas positivas e, na grande maioria, superiores em magnitude às correlações fenotípicas e ambiental. A mesma tendência foi observada para os genótipos precoces cultivados no telado. Os maiores valores de correlação genotípica ocorreram entre os caracteres PSR e CRP $(0,765)$, PSR e CPA $(0,920), \operatorname{CRP}$ e PSA $(0,629)$, CPA e PSA $(0,705)$. Outros caracteres mostraram correlações genotipicas em torno de 0,5, como por exemplo: PSR e PSA $(0,497)$, CPA e CRP $(0,558)$. Esses resultados assemalham-se com os de CARRASCO \& GONZALEZ (1985), FARIA NETO (1987), GARLAND \& FEHR (1981).

Um fato que chama a atenção é a discrepāncia entre as correlações fenotípica $\left(r_{F}\right)$ e genotípica $\left(r_{G}\right)$ entre PSR e CPA: $r_{F}=-0,0126$ e $r_{G}=0,920$. Este fato reforca a afirmativa de que a magnitude de $r_{F}$ deve ser encarada com certo cuidado, pois nela estão contidos, não só os fatores genéticos, mas também, os ambientais. Aparentemente, o ambiente anulou a correlação genotípica existente entre PSR e CPA. Este efeito tem reflexos aplicados negativos, pois torna-se dificil classificar e selecionar genótipos pela simples avaliação fenotípica dos dois caracteres. FALCONER (1981) também . comenta a esse respeito.

Aqueles caracteres com valores pequenos $1<$ $0,3)$ de coeficiente de correlação, devem possuir pouca ou nenhuma associação.

Pelos dados da Tabela 23, verifica-se que todas as correlações (genotỉpicas, fenotípicas e ambientais) 
entre produtividade e acamamento sảo de pequena magnitude. As correlações genotípicas mostraram tendência de serem negativas; apenas em Sertãozinho ocorreu valor negativo e de média magnitude $\left(\mathrm{r}_{G}=-0,403\right)$; para este ambiente em particular, a associação entre os dois caracteres seria favorável, pois as plantas produtivas teriam tendência de serem eretas (menores valores de acamamento). Todavia, deve-se considerar que, para os três locais em conjunto, os dois caracteres são relativamente independentes e devem ser considerados nos programas de seleção, pois as associações entre eles são relativamente casuais, podendo.ocorrer plantas produtivas acamadas, plantas exetas improdutivas e plantas improdutivas acamadas entre as combinações desejáveis, ou seja, plantas produtivas eretas.

A Tabela 24 mostra as correlações intraclasses entre os caracteres avaliados em telado e campo. Nesta tabela, verifica-se que todas as correlações tiveram magnitudes próximas de zero. Isto mostra a total falta de associação entre os dados de telado com os de campo. Esta falta de correlação entre os caracteres, talvez seja devido em grande parte à forte influência dos ambientes (telado e campo) onde foram conduzidos os experimentos. Também, as diferentes idades de avaliações (30 dias em telado e próximo à colheita em campo), podem ter contribuído para a falta de associação entre os caracteres neste grupo de genótipos semi-precoces.

\subsection{Grupo semi-tardio}

Neste grupo de maturação da soja foram eliminados os genótipos 45 (IAC 2), 46 (Ivaỉ), 47 (Missões), 48 (BR 3), 49 (Tennessee New Pop), 50 (Vila Rica), 51 (OC 79- 
-39) e a testemunha IAC 8, por não germinarem em condições de telado e por apresentarem muitas falhas nas parcelas de campo (estande muito baixo). Fm vista disso, este grupo de maturação de soja passa a ter 44 genótipos e cinco testemunhas.

As análises de variāncia das testemunhas, para os caracteres avaliados nos experimentos conduzidos no telado e em campo, considerando conjuntos de tratamentos, encontram-se nas Tabelas 25 e 26, respectivamente. Os efeitos de conjuntos (C) e da interação conjuntos e testemunhas (C $\mathrm{x}$ T), não apresentaram significância, para todos os caracteres estudados, permitindo conduzir as análises de variâncias em blocos casualizados.

Os coeficientes de variação, para $\operatorname{PSR}(\mathrm{CV}=$ $35 \circ)$ e de PSA ( CV = 21\%), foram altos o que poderá ter mascarado alguma estimativa de parâmetro(s) genético(s), principalmente, se a ação gênica desse(s) parâmetro(s) for(em) do tipo não aditivo.

\subsubsection{Experimentos em telado}

Os experimentos foram planejados para avaliação em duas épocas: 30 e 45 dias, com três repetições. Os resultados das análises de variância dessas épocas encontram -se nas Tabelas 27, 28 e 29. Na Tabela 29, verifica-se que não houve efeitos significativos de época (F.p) e da interação genótipos e épocas (G x Ep), o que permitiu a reunião das duas épocas, passando o experimento a ter seis repetições. 


\section{a. Peso seco de raïzes (PSR)}

Os resultados obtidos na Tabela 30 demonstram que houve diferenças altamente significativas entre os genótipos semi-tardios, apesar do elevado coeficiente de variação (41\%), que poderia ter mascarado as diferenças genotipicas.

o comportamento médio dos genótipos encontra -se na Tabela 31. Verifica-se que a amplitude de variação foi de 0,23 (Santa Rosa - verde) a 0,54.(São Luiz) g/planta. Além de 'são Luiz', 16\% dos genótipos apresentaram excelente comportamento relativo, com valores médios iguais ou superiores a 40 g/planta: BR 5, FT 8, GO 81-11103, Hardee, IAC 5, S 66 e Savana. Além disso, 68 o dos genótipos apresentaram comportamento superior à média das testemunhas $130 \mathrm{~g} /$ planta) .

Pelos valores dos coeficientes de variação genotipica $(12,5 \%$, Tabela 30) e determinação genotípica, $(0,357$, Tabela 35) pode-se constatar pequena variabilidade no PSR, fato que deve dificultar o processo de seleção. Resultados semelhantes foram observados para PSR nos genótipos precoces e semi-precoces.

\section{b. Peso seco da parte aérea (PSA)}

Houve diferenças altamente significativas entre genótipos e o coeficiente de variação foi médio alto (CV $=26,8 \%$, Tabela 30).

A amplitude de variação foi 0,70 (IAC 7) a 1,56 (São Luiz) g/planta. Além de 'São Luiz', $11 \%$ dos genó- 
tipos apresentaram ótimo comportamento relativo, cujos valores médios foram iguais ou superiores a $1,15 \mathrm{~g} / \mathrm{planta}$ : BR 5 , Hardee, IAC 5, S 66 e Yelnanda. Constata-se ainda, que 70\% dos genótipos apresentaram comportamento médio superior à média das testemunhas $(0,92 \mathrm{~g} / \mathrm{planta,} \mathrm{Tabela} \mathrm{31).}$

Analisando as estimativas obtidas para os coeficietnes de determinação genotípica $(0,514$, Tabela 35), e de variação genotípica $(11,3 \%$, Tabela 30$)$, pode-se concluir pela existência de uma razoável variabilidade no PSA. As magnitudes destes dois parâmetros estimados para os genótipos semi-tardios são relativamente semelhantes àquelas obtidas para os genótipos precoces e semi-precoces para PSA.

\section{c. Comprimento da raiz principal (CRP)}

Na Tabela 30 constata-se que não houve diferenças significativas entre os genótipos, apesar do coeficiente de variação $(\mathrm{CV}=13,3$ 응 ter sido relativamente baixo.

A amplitude de variação foi 43,2 (Avaré) a 55,4 cm/planta (Mineira). Além de 'Mineira', 11 \% dos genötipos mostraram comportamento médio superior a $51 \mathrm{~cm} / \mathrm{planta:}$ 'Andrews', BR 5, Ga 78-2708, GO 81-8065 e 'Savana'. Além disso, $48 \%$ dos genótipos apresentaram CRP superior à média das testemunhas, que foi de $48,1 \mathrm{~cm} /$ planta (Tabela 31). Resultados semelhantes também foram obtidos por KASPAR et alii (1984), em taxas de crescimento diário da raiz principal.

As estimativas dos coeficientes de variação genotipica de $1,73 \%$ (Tabela 30) e de determinação genotipica de 0,0916 (Tabela 35), demonstram a ausência de variabilidade entre os genótipos semi-tardios. Tais resultados são re- 
lativamente semelhantes àqueles obtidos para os genótipos semi-precoces. No entanto, a variabilidade genética do CRP manifestou-se em niveis altos nos genótipos precoces.

\section{d. Comprimento da parte aérea (CPA)}

Para esse caráter, a análise de variāncia revelou diferenças altamente significativas entre os genótipos semi-tardios, com um CV de 16,4\% (Tabela 30).

A amplitude de variação foi de 57,8 (Paranagoiana) a 82,7 (BR 5) cm/planta. Além da BR 5, $18 \%$ dos genótipos apresentaram CPA superior a $75 \mathrm{~cm} /$ planta: IAS-3, 'Dourados', GO 79-7011, GO 81-11081, La 76-1459, SOC 81-266, Tiaraju e Viçoja. Além disso, 61 o dos genótipos apresentaram comportamento médio superior à média das testemunhas $(67,9 \mathrm{~cm} / \mathrm{pl}$ anta; Tabela 31). Resultados semelhantes foram obtidos por CHAUHAN \& ŚSNGH (1984), EGLI et alii (1985), FOLEY et alii (1986), GARLAND \& FEHR (1981), que obtiveram variações na altura da planta, de 58,9 a 106,5; 25 a 108; 59,5 a 106,$5 ; 79$ a $83 \mathrm{~cm}$, respectivamente.

As estimativas dos coeficientes de variação genotipica de 5,30\% (Tabela 30 ( e de determinação genotípica de 0,384 (Tabela 35) revelam que CPA tem variabilidade 1imitada nos genótipos semi-tardios. O nivel de variabilidade genética em CPA foi maior nos genótipos semi-precoces e ainda maior nos genótipos precoces. 


\subsubsection{Experimentos em campo}

\section{a. Anhembi}

Pelos resultados apresentados na Tabela 32 verifica-se que houve diferenças altamente significativas entre os genótipos semi-tardios para produtividade e acamamento. Os coeficientes de variação foram relativamente médios, ou seja, 17,2\% para produtividade e 5,6\% para acamamento.

O comportamento médios dos gen̋́tipos, para esses dois caracteres, encontra-se na Tabela 33. A produtividade apresentou variação de 792 kg/ha (Ga 78-2708) e 2500 $\mathrm{kg} / \mathrm{ha}$ (Savana). No geral, a produtividade esteve próxima da média de são Paulo, que oscila em torno de $2000 \mathrm{~kg} / \mathrm{ha}$; 36\% dos genótipos tiveram produtividade superior à essa média; $25 \%$ dos genótipos apresentaram produtividade superior à média das testemunhas (2083 kg/ha). FOLFY et alii (1986), em avaliações, em trēs locais, em plantas determinadas e indeterminadas, obtiveram niveis de variabilidade semelhantes.FA RIAS NETO (1987) e WILCOX et alii (1984), obtiveram produtividade similares nos genótipos em outras condições de avaliação.

As estimativas dos coeficientes de determinação genotipica ( $b=0,583$, Tabela 36$)$, e de variação genotipica $\left(\mathrm{CV}_{\mathrm{G}}=14,4 \%\right.$, Tabela 32$)$, revelam que a variabilidade genética do grupo semi-tardio foi um pouco inferior àquela observada no grupo semi-precoce para produtividade em Anhembi.

Para o acamamento, pode-se verificar na Tabela 33, que, houve variação, em termos de nota, de $1(1,41$ em 
dados transformados) a 2,42 (1,85 em dados transformados), e a média geral foi inferior a das testemunhas 11,25 , em termós de nota e 1,5 em termos de dados transformados). Assim, 75\% dos genótipos acamaram menos do que a média das testemunhas. Resultados semelhantes foram obtidos por FOLEY

et alii (1986), JOHNSON et alii (1955b) e WILCOX et alii (1984).

Analisando os coeficientes de variação genotipica $\left(\mathrm{CV}_{\mathrm{G}}=6,1 \%\right.$, Tabela 32$)$ e de determinação genotípica $(b=0,710$, Tabela 36$)$, verifica-se que o acamamento apresentou tendência semelhante àquela observada para produtividade, ou seja, a variabilidade genética no grupo semi-tardio foi um pouco menor do que no grupo semi-precoce.

\section{b. Sertãozinho}

Neste local, foram detectadas diferenças significativas entre os genótipos semi-tardios para acamamento. Produtividade apresentou coeficiente de variação experimental relativamente baixo $(\mathrm{CV}=12,1 \%)$, nas não foi detectada diferenças significativas entre os genótipos semi-tardios.

As médias de produtividade e acamamento encontram-se na Tabela 33. A produtividade apresentou variação de $2000 \mathrm{~kg} / \mathrm{ha}$ (IAC 5) a $3417 \mathrm{~kg} / \mathrm{ha}$ (SOC 81-216). Em relação à média das testemunhas $(2583 \mathrm{~kg} / \mathrm{ha}), 36 \%$ dos genótipos apresentaram comportamento superior. Os coeficientes de determinação genotípica $(b=0,376$, Tabela 36$)$, e de variação genotipica $\left(\mathrm{CV}_{\mathrm{G}}=6,70 \%\right.$, Tabela 32$)$ foram inferiores às estimativas do grupo semi-precoce em Sertãozinho e Anhembi e também inferiores as estimativas do grupo semi-tardio em Anhembi, para produtividade. 
Com relação ao acamamento a variação, em termos de nota, foi de 1,0 (1,41 em dados transformados) a 4,24 (2,29 em dados transformados) (Tabela 33). Além disso, 61\% dos genótipos apresentaram comportamento superior à média das testemunhas $(2,06$, em termos de nota e 1,75, em dados transformados). Resultados similares foram obtidos por FOLEY et alii (1986), JOHNSON et alii (1955b) e WILCOX et alii (1984) .

Os coeficientes de determinação genotípica $(b=0,893$, Tabela 36$)$ e de variação genotipica $\left(\mathrm{CV}_{\mathrm{G}}=15,2 \%\right.$, Tabelas 36 e 32, respectivamente) confirmaram a existência de ampla variabilidade genética para acamamento, anteriormente já relatada para os genótipos semi-precoces em Anhembi e Sertãozinho e para os genótipos semi-tardios em Sertãozinho.

\section{c. ESALQ}

De acordo com a análise de variância apresentada na Tabela 32 não foi detectada diferença significativa na produtividade dos genótipos semi-tardios cultivados na ESALQ. Tal fato deve ter ocorrido em consequência do valor relativamente alto de coeficiente de variação experimental $(\mathrm{CV}=22,7 \%)$. Já para acamamento, foram detectadas diferenças estatisticamente significativas.

As médias de produtividade e acamamento, encontram-se na Tabela 33. A produtividade apresentou variação de $1771 \mathrm{~kg} / \mathrm{ha}$ (Avaré) a $3521 \mathrm{~kg} / \mathrm{ha}$ (Viçoja). A média das testemunhas foi de $2854 \mathrm{~kg} / \mathrm{ha}$ e $23 \%$ dos genótipos foram superiores a essa média. WILCOX \& SEDIYAMA (1981), encontraram variação de 1651 e $4305 \mathrm{~kg} / \mathrm{ha}$ na produtividade de linha- 
gens de porte determinado.

O coeficiente de determinação genotípica $(b=$ $2,55 \times 10^{-9}$, Tabela 36), associado com o coeficiente de variação genotípica $\left(\mathrm{CV}_{\mathrm{G}}=7,8 \times 10^{-4}\right.$, Tabela 32), revelam a ausência de variabilidade entre os genótipos semi-tardios cultivados na ESALQ. Tais estimativas foram muito inferiores às estimativas obtidas para os genótipos semi-precoces e semi-tardios nos três locais. Esta discrepāncia de resultados pode ser explicada pelos valores altos de coeficiente de variação experimental do experimento de.genótipos semi-tardios cultivados na ESALQ. Alto CV foi consequência do valor baixo da média geral de produtividade $(2654 \mathrm{~kg} / \mathrm{ha}$, Tabela 33).

Para o acamamento, a variação em termos de notas, foi de $1,0(1,41$ em dados transformados) a 4,76 $(2,40$ em dados transformados). Por outro lado, $61 \%$ dos genótipos tiveram comportamento superior à média das testemunhas (1,69, em termos de notas e 1,64, em dados transformados) (Tabela 34). WILCOX et alii (1984), obtiveram variação (em notas) de 1,5 a 4,2, nas familias de baixo e alto acamamento, respectivamente.

As magnitudes dos coeficientes de determinação genotípica de 0,836 (Tabela 36) e de variação genotípica de $14 \%$ (Tabela 32), revelam a razoável variabilidade genética existente em acamamento. Tal fato tem sido uma constante nos genótipos semi-precoces e semi-tardios cultivados nos três locais. 


\section{d. Análise conjunta dos três locais}

As análises conjuntas dos très locais revelaram significância estatística entre locais para produtividade e da interação genótipos e locais para acamamento (Tabela 34). Esses resultados indicam que os locais exerceram efeitos semelhantes na produtividade dos genótipos semi-tardios. Realmente, pode-se observar na Tabela 33 que os genótipos Andrews, IAS-3 e Paranagoiana apresentaram altos niveis de produtividade nos três locais, enquanto que os genótipos CEPS 10, Ga 78-2708 e Hardee, tiveram produtividades inferiores. A produtividade dos genótipos semi-tardios aumentou de Anhembi para Sertãozinho e para ESALQ.

No caso de acamamento, os genótipos semi-tardios apresentaram comportamento diferencial nos locais onde foram avaliados. Por exemplo, GO 79-7012 recebeu notas médias 3,5 (Sertãozinho), 2,4 (ESALQ), 1,2 (Anhembi); outro genótipo, GO 79-1030, obteve notas 3,2 (Sertãozinho) e 1,9 (Anhembi e ESALQ); GO 81-11081, obteve notas: 4,76 (ESALQ), 4,02 (Sertãozinho) e 1,62 (Anhembi). Outros genótipos tambêm contribuíram para a interação, mas os principais foram esses mencionados.

\subsubsection{Correlações genotipica $\left(r_{G}\right)$, fenotipica $\left(r_{F}\right)$} e ambiental $\left(r_{A}\right)$ e correlações intra-classe entre caracteres avaliados no telado e em cam po

Para os genótipos semi-tardios, as estimativas dos coeficientes de correlação genotípica, fenotípica e ambiental, entre os quatro caracteres avaliados em condições de teḷado encontram-se na Tabela 35; entre os dois ca- 
racteres avaliados em campo, as correlações estão na Tabela 36.

Verifica-se na Tabela 35 que as correlações genotípicas foram geralmente superiores e de mesmo sinal que as correlações fenotípicas. O mesmo tipo de tendência foi observado para os genótipos precoces e semi-precoces avaliados no telado.

A magnitude da correlação genotípica entre PSR e PSA $(0,996)$ revelou uma fortissima associação entre esses dois caracteres nos genótipos semi-tardios. Fste fato poderia ser esperado, pois quanto mais pesado o sistema radicular - maior número e/ou volume do sistema radicular-espera-se uma maior capacidade de absorção de ägua e nutrientes, resultando em plantas mais vigorosas e maior peso da parte aérea. Resultados similares foram encontrados por GIUROVA \& ILCHEVA (1985) e GARLAND \& FEHR (1981), em outros caracteres e em condições de campo. Todavia, a correlação genotipica entre PSR e PSA não foi tão forte nos genótipos precoces $(0,748)$ e nem nos genótipos semi-precoces $(0,497)$.

A correlação entre PSR e $\operatorname{CRP}(0,570)$ nos genótipos semi-tardios foi superior àquelas observadas nos genótipos semi-precoces $(0,765)$ e nos genótipos precoces $(0,978)$; para os três grupos de maturação houve evidência de associação positiva e relativamente forte entre PSR e CRP.

A correlação genotípica de $-0,231$ entre PSR e CPA mostra uma fraca ou nula associação entre esses dois caracteres. O sinal negativo, indicando que quando um caräter aumenta o outro diminui, pode ser explicado pela influência ambiental; realmente, a correlação ambiental entre esses dois caracteres $\left(r_{A}=-0,296\right)$, embora baixa e não sig- 
nificativa, tende a reduzir e/ou mascarar os resultados das correlações genotípicas e fenotípicas. Resultado semelhante foi observado para os genótipos precoces $\left(r_{G}=0,0652\right)$. Todavia, a correlação genotípica entre PSR e CPA foi muito alta $\left(r_{G}=0,920\right)$ nos genótipos semi-precoces. REICOSKY et alii (1970) comentam que é preferível usar comprimento ao invés de peso de raiz, poque a absorção de água e nutrientes é função do comprimento e não do peso de raízes.

A correlação genotípica entre CRP e PSA $(-0,182)$ foi praticamente nula, em parte devido a influência ambiental, mostrada pela correlação ambiental $(0,392)$. o pequeno valor da correlação entre CRP e PSA nos genótipos semi - tardios não confirmou as correlações genotípicas relativamente altas observadas nos genótipos precoces $(0,714)$ e semi-precoces $(0,629)$.

A correlação praticamente nula entre CPA e PSA $(0,0792)$ nos genótipos tardios não concorda nem com a dos genótipos precoces $(0,332)$ e nem com a dos genótipos semi-precoces $(0,705)$.

A correlação genotípica encontrada entre comprimento da parte aérea e comprimento da raiz principal ( $\mathrm{r}_{\mathrm{G}}$ $=-0,450)$, indicou uma associação negativa, altamente significativa, isto é, à medida que a parte aérea aumenta, diminui o comprimento da raiz principal e vice-versa. Esse resultado foge um pouco do esperado - quanto maior o comprimento da raiz, mais vigorosa deve ser a planta. De fato, a correlação negativa observada nos genótipos semi-tardios não concorda com as correlações positivas dos genótipos precoces $(0,312)$ e dos genótipos semi-precoces $(0,558)$.

Nos experimentos de campo com os genótipos se- 
mi-tardios, as correlações variaram entre os trēs locais (Tabela 36). As correlações fenotípicas e genotípicas foram estimadas respectivamente em: 0,359 e 0,315 (Anhembi),-0,431 e -0,788 (Sertãozinho), 0,262 e zero (ESALQ). Estes resultados foram bem semelhantes aos observados para os genótipos semi-precoces. Desta maneira, produtividade e acamamento devem ser avaliados e considerados nos programas de seleção.

A Tabela 37 mostra as correlações intra-classe entre os caracteres avaliados em telado e no campo. A exemplo do grupo semi-precoce, também neste caso, as correlações foram todas de magnitude próxima a zero, mostrando falta de associação entre os caracteres. Esta falta de correlação pode ser também devida à forte influência dos ambientes (telado e campo) e às diferentes épocas em que foram feitas as avaliações (aos 30 dias no telado e próximo à colheita no campo).

\subsection{Grupo tardio}

Neste grupo foram eliminados os genótipos 17 (Cristalina 2), 18 (IAC 9), 19 (UFV 2), 20 (GO 79-1084), 21 $(B R$ 10) e 22 (BR 79-63), por não haverem germinado em condições de telado, e por apresentarem muitas falhas nas parcelas de campo.

As análises de variāncia das testemunhas, para os caracteres avaliados em condições de telado e campo, considerando conjuntos de genótipos, encontra-se nas Tabelas 38 e 39. Verifica-se que os efeitos de conjuntos (C) e da interação conjuntos e testemunhas (C $x$ T) não apresentaram significāncia para todos os caracteres avaliados, possibilitando. conduzir as análises de variāncias de todos os ge- 
nótipos em blocos casualizados.

\subsubsection{Experimento em telado}

Da mesma maneira que o grupo de maturação semi-tardio, os experimentos foram planejados para avaliação em duas épocas (30 e 45 dias) com três repetições. Os resultados das análises de variância dessas épocas encontram-se nas Tabelas 40, 41 e 42. Na Tabela 42 verifica-se que não houve efeitos significativos de épocas e da interação testemunhas $x$ épocas, o que permitiu a ignoração das épocas e a reunião das repetições, passando o experimento de avaliações dos caracteres de telado a possuir seis repetições.

\section{a. Peso seco de raizes (PSR)}

Os resultados obtidos na Tabela 43 revelam que houve diferenças altamente significativas entre genótipos tardios, apesar do coeficiente de variação muito elevado $(\mathrm{CV}=45 \%)$, que poderia ter mascarado as diferenças entre genótipos.

As médias dos genótipos tardios encontram-se na Tabela 44. Verifica-se que a amplitude de variação foi de 0,17 (GO 79-1039) a 0,54 (Timbira 1) g/planta e que 56: dos genótipos apresentaram comportamento superior à média das testemunhas $(0,34 \mathrm{~g} / \mathrm{planta})$. Desses, Timbira 1, Cristalina, Paranagoiana, EMGOPA 301 e UFV 1 apresentaram magnitude igual ou superior a $0,40 \mathrm{~g} / \mathrm{planta}$.

As magnitudes dos coeficientes de determinação genotípica de 0,623 (Tabela 48) e variação genotípica 
(23,9\%, Tabela 43) revelam que existe razoävel quantidade de variabilidade genética no PSR dos genótipos tardios, contrariando as indicações de variabilidade limitada obtidas nos genótipos precoces, semi-precoces e semi-tardios.

\section{b. Peso seco da parte aérea (PSA)}

Na Tabela 43, verifica-se que houve diferenças altamente significativas entre genótipos para PSA, com um coeficiente de variação de 24 용.

Pela Tabela 44 constata-se que os genótipos variaram de 0,54 (GO 79-1039) a $1,02 \mathrm{~g} / \mathrm{planta}$ (UFV 1), e que 50 을 foram superiores à média das testemunhas $(0,86 \mathrm{~g} / \mathrm{planta})$.

Pelas magnitudes dos coeficientes de determi-nação genotípica de 0,706 (Tabela 48) e de variação genotipica de 15,1 옹 (Tabela 43), parece existir quantidade um pouco maior de variabilidade genética em PSA nos genótipos tardios do que nos precoces, semi-precoces e semi-tardios.

\section{c. Comprimento da raiz principal (CRP)}

Apesar do controle experimental eficiente (CV (12\%), não foi detectada diferença significativa entre os genótipos tardios para CRP (Tabela 43).

A amplitude de variação dos genótipos tardios foi de 48,5 (TN 82-264) a 59,9 cm/planta (Paranagoiana) e $56 \%$ dos genótipos apresentaram comportamento médio superior à média das testemunhas $(52,8 \mathrm{~cm} / \mathrm{planta})$. Paranagoiana, Cristalina, EMGOPA 301, Numbaira, PI 240-664 e Timbira 2, 
apresentaram médias de CRP superiores a $54,0 \mathrm{~cm} / \mathrm{planta}$ (Tabela 44). KASPAR et alii (1984), encontraram amplitudes maiores, ou seja, diferença de $120 \mathrm{~cm}$ em CRP entre dois grupos de maturação de soja.

Os coeficientes de determinação genotípica de 0,274 (Tabela 48) e de variação genotípica de 3응 (Tabela 43) demonstram a existência de pequena quantidade de variabilidade genética entre os genótipos tardios para CRP. Aparentemente existe um gradiente de decréscimo de variabilidade dos genótipos precoces apra semi-precoces, semi-tardios e tardios.

\section{d. Comprimento da parte aérea (CPA)}

De modo semelhante ao que ocorreu em

CRP, apesar do controle experimental eficiente ( $C V=14 \%$ não foi detectada diferença significativa entre os genótipos tardios para CPA.

Na Tabela 44, encontram-se as médias dos genótipos tardios, onde se verifica que a variação foi de 57,3 (UFV 5) a 74,7 cm/planta (Timbira 2) e que, 62\% dos genótipos apresentaram comportamento superior à média das testemunhas $(63,9 \mathrm{~cm} / \mathrm{planta})$. Timbira, PI 240664 e UFV 1, apresentaram magnitudes médias de 73,4 e $72,9 \mathrm{~cm} / \mathrm{planta}$, respecti vamente. Resultado semelhante Foi obtido por RAJPUT et alii (1987), que encontraram uma média, para altura de plantas, de $68,7 \mathrm{~cm} / \mathrm{planta}$. SAMAH et alii (1984) encontraram variação para altura de planta de 45 a $115 \mathrm{~cm}$. JOHNSON et alii (1955b) encontraram alturas médias de 45,3 e 40,1 cm/planta, para duas populações de soja. 
As estimativas dos coeficientes de determinação genotípica de 0,498 (Tabela 48) e de variação genotípica de 5,58 (Tabela 43) indicaram que a variabilidade genética em CPA tem magnitudes semelhantes nos genótipos tardios, semi-tardios e semi-precoces. Já os genótipos precoces apresentaram maior quantidade de variabilidade genética em CPA. Em soja, realmente ocorre muita variação no desenvolvimento da parte aērea, mesmo nas fases iniciais de desenvolvimento. Em Piracicaba, amplitudes de 59 a $138 \mathrm{~cm}$ (verão) e de 26 a $94 \mathrm{~cm}$ (inverno) na altura da planta no florescimento foram encontradas por FARIAS NETO (1987).

\subsubsection{Experimentos em campo}

\section{a. Anhembi}

Pelos resultados apresentados na tabela 45, foram detectadas diferenças significativas entre os genótipos tardios para produtividade e para acamamento.

Na Tabela 47, encontram-se as médias dos genótipos avaliados. Pode-se verificar que a produtividade variou de 437 (TN 82-264) a $2667 \mathrm{~kg} / \mathrm{ha}$ (UFV Araguaia). Além disso, apenas dois genótipos (UFV Araguaia e UFV 5) apresentaram produtividade superior à média das testemunhas 12583 $\mathrm{kg} / \mathrm{ha}$ ). A média geral foi de $2083 \mathrm{~kg} / \mathrm{ha}$. Esses resultados são próximos dos obtidos por FOLEY et alii (1986), RAJPUT et alii (1987), SARMAH et alii (1984) e WILCOX \& SEDIYAMA (1981) .

Os coeficientes de determinação genotípica $(b=0,585$, Tabela 49$)$ e de variação genotípica $\left(\mathrm{CV}_{\mathrm{G}}=20,4 \%\right.$, Tabela 45), dos genótipos tardios foram semelhantes aos coe- 
ficientes estimados para os genótipos semi-precoces e semi-tardios em Anhembi, todos eles indicando a existência de razoável quantidade de variabilidade genética em produtividade.

Para acamamento, a variação encontrada em termos de nota foi de $1,0(1,41$ em dado transformado) a 4,52 $(2,35$ em dado transformado); 43,7\% dos genótipos apresentaram comportamento superior à média das testemunhas $(1,53$ em termos de nota e 1,59 em dados transformados, Tabela 47). Esses resultados estão de acordo com os, de FOLEY et alii (1986), WILCOX et alii (1984) e JOHNSON et alii (1955a).

Os coeficientes de determinação genotípica de 0,734 (Tabela 49) e de variação genotípica de 14\% (Tabela 45) foram relativamente altos. A existência de grande quantidade de variabilidade genética no acamamento foi uma constante nos quatro grupos de maturação. FARIAS NETO também observou o mesmo fato $(b=0,858)$ em genótipos tardios cultivados no verão.

\section{b. Sertãozinho}

De maneira semelhante ao que foi observado em Anhembi, os genótipos tardios também apresentaram diferenças significativas em Sertãozinho, tanto para produtividade quanto para acamamento.

A média de produtividade variou de 1625 82-264), a $2854 \mathrm{~kg} / \mathrm{ha}$ (Paranagoiana); 50\% dos genótipos tiveram comportamento superior à média das testemunhas 12542 $\mathrm{kg} / \mathrm{ha})$ - Os quatro melhores genótipos foram: Paranagoiana (2854 kg/ha), EMGOPA 301 (2812 kg/ha), Cristalina $(2750 \mathrm{~kg} /$ 
ha) e Numbaira $(2750 \mathrm{~kg} / \mathrm{ha})$. Alguns autores encontraram variações semelhantes na produtividade, entre eles: FOLEY et alii (1986), SARMAN et alii (1984), WILCOX \& SEDIYAMA (1981) e YAP \& LEE (1977).

Analisando as magnitudes dos coeficientes de determinação genotípica ( $b=0,871$, Tabela 49) e de variação genotipica $\left(\mathrm{CV}_{\mathrm{G}}=13,6 \%\right.$, Tabela 45$)$, se verifica que foram superiores aos obtidos para os genótipos semi-tardios e semi -precoces. Em Sertãozinho, maiores niveis de variabilidade genética ocorreram nos genótipos tardiós; menores níveis de variabilidade ocorreram nos genótipos semi-tardios; os genótipos semi-precoces mostraram nivel intermediário da variabilidade na produtividade. FARIAS NETO (1987) obteve 0,564 para o coeficiente de determinação genotípica. RAJPUT et alii (1987) obtiveram coeficiente de variação de 39\%; os autores comentam que um alto valor para coeficiente de variação genotipica $\left(\mathrm{CV}_{\mathrm{G}}\right)$ mereceria confiança se for acompanhado por uma alta estimativa da herdabilidade.

Com relação ao acamamento, a variação obtida em termos de nota foi de $1,0(1,41$, em dado transformado) a $4,20(2,28 \mathrm{em}$ dado transformado), onde 568 dos genótipos acamaram menos que a média das testemunhas que foi de 2,53, em termos de nota e 1,88 em dado transformado (Tabela 47). Variações semelhantes, em acamamento, foram obtidas por FOLEY et alii (1986), JOHNSON et alii (1955a) e WILCOX et alii $(1984)$.

Os valores obtidos para as estimativas dos coeficientes de determinação genotípica $(0,904$, Tabela 49) e de variação genotipica $(15,7 \%$, Tabela 45), confirmaram a tendência do acamamento apresentar altos niveis de variabilidade genética nos vários grupos de maturação e nos diferentes locais. 


\section{c. ESALQ}

Houve diferenças significativas entre os genótipos tardios para a produtividade; não foi detectada diferença significativa para acamamento (Tabela 45).

A amplitude de variação para a produtividade foi de 542 (TN 82-264) a 3604 kg/ha (Paranagoiana); 50\% dos genótipos foram superiores à mëdia das testemunhas $(3187 \mathrm{~kg} /$ ha). Os quatro melhores genótipos foram: Paranagoiana, FMGOPA 301 e Numbaira com 3583 kg/ha e UFV Araguaia com 3500 $\mathrm{kg} / \mathrm{ha}$. Excetuando TN 82-264, o comportamento geral dos genótipos foi superior a $2300 \mathrm{~kg} / \mathrm{ha}$, o que é uma excèlente produtividade (Tabela 47). Fisses resultados são semelhantes aos de FARIAS NFTO (1987), FOLFY et alii (1986), SARMAH et alii (1984) e YAP \& LFE (1977).

Os coeficientes de determinação genotipica $(b=0,79$, Tabela 49$)$ e de variação genotípica $\left(\mathrm{CV}_{\mathrm{G}}=23 \%\right.$, Tabela 45) para a produtividade de genótipos tardios cultivados na FSALQ, foram semelhantes aos de Sertãozinho e superiores aos de Anhembi. Niveis relativamente altos de variabilidade para produtividade também foram encontrados nos demais grupos de maturação, com exceção do grupo semi-tardio cultivado na FSALQ. Níveis satisfatórios de variabilidade genética na produtividade também foram obtidos por outros autores (FARIAS NETO, 1987; RAJPUT et alii, 1987).

Com relação ao acamamento (Tabela 47), a variação em termos de nota foi de 1,0 (1,41 em dado transformado) a 4,66 (2,38 em dado transformado); 44ㅇoㅇ dos genótipos acamaram menos que a média das testemunhas $(3,28$, em termos de nota e 2,07 em dado transformado). Resultados semelhantes foram obtidos por JOHNSON et alii (1955a), em duas popu- 
lações de soja.

Apesar do genótipo Timbira 2 haver rocobido nota 4,66, que significa plantas praticamente prostradas, a sua produtividade foi muito boa (3312 kg/ha), enquanto que, TN 82-264, com nota 1,0, que significa plantas eretas, apresentou produtividade muito baixa $(542 \mathrm{~kg} / \mathrm{ha})$. Assim, de uma maneira geral, acamamento não limitou a produtividade. O acamamento têm implicações sérias na colheita,pois esta é totalmente mecanizada em soja. Geralmente, as linhagens com alto grau de acamamento tendem a apresentar maiores perdas na colheita e, muitas vezes, tem indices superiores de deterioração de vagens devido ao contato com o solo.

Os coeficientes de determinação genotípica $\left(b=0,423\right.$, tabela 49) e de variação genotípica $\left(\mathrm{CV}_{\mathrm{G}}=7,7 \%\right.$, Tabela 45) foram bastante inferiores aos observados para os demais grupos de maturação nos très locais.

\section{d. Análise conjunta}

A análise conjunta apresentada na Tabela 46 , detectou efeitos significativos para locais, tanto para produtividade quanto para acamamento. A interação entre genötipos e locais ( $\mathrm{x}$ x L) não foi significativa em nenhum dos dois caracteres. Isto indica que os efeitos de locais foram relativamente semelhantes em todos os genótipos tardios. Em termos de produtividade, os genótipos semi-tardios também não interagiram com os locais; todavia, os genótipos semi-precoces mostraram interação significativa. No caso de acamamento, tanto os genótipos semi-precoces quanto o semi-tardios mostraram interação significativa com os locais. 
4.4.3. Correlações genotipica $\left(r_{G}\right)$, fenotipica $\left(r_{F}\right)$, ambiental $\left(r_{A}\right)$ e correlação intra-classe $\left(r_{I C}\right)$ entre os caracteres avaliados cm telado e no campo

Para os genótipos tardios, as estimativas de coeficientes de correlação genotípica, fenotípica e ambiental entre os quatro caracteres avaliados no telado encontram - se na Tabela 48; as correlações entre os dois caracteres avaliados no campo encontram-se na Tabela 49.

De acordo com a Tabela 48 , as correlações genotípicas foram pouco superiores às correlações fenotípicas. Obtiveram-se estimativas altas de correlações genotípicas entre os caracteres $\operatorname{PSR}$ e $\operatorname{PSA}(0,910), \operatorname{PSR}$ e $\operatorname{CRP}(0,724), \operatorname{CRP}$ e PSA $(0,570)$. As demais correlações genotípicas foram próximas de zero. Resultados semelhantes ocorreram com os genótipos precoces e semi-precoces. Todavia, para os genótipos semi-tardios, duas das seis correlações genotípicas não obedeceram à mesma tendēncia dos demais grupos de maturação: CRP e PSA $(-0,182), \operatorname{CRP}$ e $\operatorname{CPA}(-0,450)$.

O alto valor encontrado para a correlação ambiental entre PSR e PSA $(0,693)$ indica que o ambiente influencia de maneira semelhante estes dois caracteres (FALCONER, 1981).

Nos experimentos de campo com os genötipos tardios, as correlações variaram entre os três locais (Tabela 49). As correlações fenotipicas e genotipicas foram estimadas respectivamente em: 0,190 e 0,154 (Anhembi), -0,243 e $-0,242$ (Sertãozinho), 0,450 e 0,992 (ESALQ). As magnitudes destas correlações diferiram daquelas obtidas para os genótipos semi-precoces e semi-tardios. A impossibilidade de 
generalizar as tendências das correlações entre produtividade e acamamento para os diversos grupos de maturação e para os diferentes locais, indica que os dois caracteres devem ser sempre avaliados e considerados nos trabalhos de seleção.

A Tabela 50 mostra as correlações intra-classe entre os caracteres avaliados em telado e em campo. Verifica-se que, de uma maneira geral, os caracteres de telado não apresentaram relacionamento com os de campo. Apenas uma fraca associação foi encontrada entre CPA e acamamento $(0,255)$.

A baixa magnitude dos coeficientes de correlação intra-classe, obtidos entre os caracteres avaliados em telado com os de campo foi uma tendência constante para todos os genótipos avaliados (semi-precoces, semi-tardios e tardios). Tanto fatores genéticos quanto fatores ambientais podem ser apontados como possíveis responsáveis pela falta de correlação entre um caráter avaliado na fase vegetativa de plantas cultivadas em telado e outro caráter avaliado na fase de maturação completa de plantas cultivadas no campo. Em primeiro lugar, a própria natureza de herança quantitativa controlando os dois caracteres torna dificil existir muitos genes envolvidos no controle simultâneo dos dois caracteres. Em segundo lugar, vem o próprio ambiente interno das plantas que possuem idades muito diferentes: 30 dias por ocasião da avaliação no telado e 110 ou mais dias durante a avaliação no campo. Em terceiro lugar, os fatores ambientais externos (umidade, luminosidade, temperatura, fertilidade do substrato) que predominam no telado são muito diferentes daqueles que atuam no campo. Sugestões para melhor avaliar o sistema radicular são a presentadas no item 4.6 . 


\subsection{Estimativas de parâmetros genéticos nas gerações $\mathrm{F}_{1}$} e $\mathrm{F}_{2}$

Os resultados obtidos nas gerações $F_{1}$ e $F_{2}$ também incluiram informações de quatro parentais precoces e de seis testemunhas. Todos estes genótipos foram cultivados apenas no telado.

\subsubsection{Variabilidade genética, herdabilidade e hete- rose}

\section{a. Peso seco de raizes (PSR)}

Os resultados da análise de variância do PSR encontram-se na Tabela 51. Verifica-se que houve efeito significativo entre genótipos, mais especificamente entre $F_{2 ' s}$ e entre Testemunhas. Os efeitos dos Parentais, $F_{1 ' s} e$ do contraste "Parentais versus $F_{1}$ 's versus $F_{2}$ 's versus Testemunhas", não revelaram significância. O coeficiente de variação genotípica para os seis $F_{2}$ 's $(22,20 \%)$, revela a boa variabilidade existente nesse caráter.

Na Tabela 52 são apresentadas as médias dos genótipos. Nota-se que, para os $\mathrm{F}_{2}{ }^{\prime} \mathrm{s}^{\prime}$ O cruzamento Ivorá $\mathrm{x}$ BR $6(0,62 \mathrm{~g} / \mathrm{planta})$, foi o que diferiu estatisticamente ( $\mathrm{P}$ $<0,01)$ de Paraná x Bragg $(0,30 \mathrm{~g} / \mathrm{planta}) \mathrm{e}$, em magnitude absoluta, foi bem superior aos demais. Observa-se, ainda, que os cruzamentos Paraná x Ivorá, Ivorá x BR 6 e Bragg x BR 6, revelaram transgressão. CAMPOS (1970), também encontrou segregação transgressiva, para alguns caracteres, em soja. No grupo dos $F_{1}$ 's' Ivorá x BR $6(0,61 \mathrm{~g} / \mathrm{planta})$, continuou liderando o comportamento médio, sugerindo uma boa combinação genotípica. 
Fim termos de média (Tabela 52), os parentais Paraná e Ivorá, são bem semelhantes (Paraná $=0,51$ g/planta e Ivorá $=0,52 \mathrm{~g} / \mathrm{planta})$, enquanto que, Bragg $(0,46 \mathrm{~g} / \mathrm{planta})$ e $\operatorname{BR} 6(0,43 \mathrm{~g} / \mathrm{planta})$, tambēm são semelhantes entre si, mas entre os dois primeiros parentais com os dois últimos, existe uma certa divergência, o que ocasionou heterose.

Na Tabela 53 verifica-se que a amplitude de variação dentro dos $F_{2}$ 's foi de 0,2633 (Paraná x Bragg) a 0,8645 (Paraná x Ivorá), indicando que este último cruzamento oferece melhores possibilidades de selecionar genótipos com melhor PSR, em gerações posteriores $\left(F_{5}\right.$ ou $\left.F_{6}\right)$. Com relação à heterose, a variação foi de $-4,17$ a $29,79 \%$ para os $F_{1 ' s}$ e de $-0,7$ a $63,8 \%$ para os $F_{2 '} s^{\circ}$ CHAUHAN \& SINGH (1982), comentam que, a presença de heterose, indica diversidade genética entre os parentais. Consequentemente, espera-se que ocorra maior nível de heterose em $F_{1}$ e maior variāncia e segregantes transgressivos em $\mathrm{F}_{2}$ e nas gerações posteriores.As gerações $\mathrm{F}_{2}$ dos cruzamentos paraná x Ivorá, Ivorá x BR 6 e Bragg $\times$ BR 6 , apresentaram heterose positiva e altamente significativa, cujos valores foram 7,7,63,8 e 22,7\%, respectivamente. Resultados semelhantes foram obtidos por CAMPOS (1979), SEDOVA (1984) e KUNTA et alii (1985), para outros caracteres.

As estimativas da herdabilidade no sentido amplo variaram de 0 a 65,89\%, o que demonstra a variabilidade entre e dentro dos $F_{2}{ }^{\prime}{ }^{\prime}$ ' possibilitando a seleção direta nesse caráter. As estimativas de herdabilidade negativas, representam estimativas de valor nulo, dependendo do intervalo de confiança. CAMPos (1979), também obteve estimativas de herdabilidades negativas, que foram consideradas nulas. 


\section{b. Peso seco da parte aérea (PSA)}

Pelos resultados obtidos na Tabela 51, verifica-se que houve diferenças significativas entre os genótipos, mais especificamente entre os $\mathrm{F}_{2}$ 's e entre as testemunhas. O baixo coeficiente de variação genotípica (4,68\%), indica a existência de pequena variabilidade genética no PSA.

A Tabela 52, apresenta as médias dos genótipos. Verifica-se que o cruzamento Ivorá.x BR 6 (1,68g/plan ta) continuou sendo o melhor dos $\mathrm{F}_{2}{ }^{\prime} \mathrm{s}$. Com relação aos $\mathrm{F}_{1}{ }^{\prime} \mathrm{s}$ ' Paraná x Bragg $(1,79 \mathrm{~g} / \mathrm{planta})$ foi o melhor. Nota-se ainda que $50 \%$ dos $\mathrm{F}_{2}$ 's e $40 \%$ dos $\mathrm{F}_{1}$ 's foram superiores à média das testemunhas $(1,28 \mathrm{~g} / \mathrm{planta})$.

Os resultados da Tabela 54, revelam que a heterose dos $F_{1}$ 's' variou de $-38,57$ a 23,45\%, ocorrendo não só heterose, mas heterobeltiose, como para os cruzamentos paraná x Bragg, 21,7\% e Ivorá x BR 6, 4\%. A heterose dos $\mathrm{F}_{2}$ 's' variou de -66,2 (Paraná x Bragg) a 38,3으 (Ivorá x BR 6); além disso, Ivorá x BR 6 apresentou heterobeltiose de 27 \% Esses resultados assemelham-se aos de WEBER et alii (1970), KAW \& MENON (1979) e CHAUHAN \& SINGH (1982) •

A herdabilidade no sentido amplo (Tabela 54) variou de 39,91 (Paraná x Bragg) a 70\% (Paraná x BR 6). Os maiores valores de herdabilidade foram obtidos para os cruzamentos, Paraná x BR 6 (70\%), Paraná x Ivorá $(67,95 \%$ ) e Ivorá x BR $6(63,97 \%)$, mostrando uma maior possibilidade de progresso com seleção, do que com os outros cruzamentos. Variações de herdabilidade, para outros caracteres, foram obtidos por CHAUHAN \& SINGH (1984), RAJPUT et alii (1987) e SISSON et alii (1976). 


\section{c. Comprimento da raiz principal (CRP)}

Os resultados da análise de variância (Tabela 51) revelam que não houve diferença estatistica entre os genótipos para CRP. Isto pode ter ocorrido devido à relativa uniformidade entre os materiais, o que pode ser constatada pela amplitude de variação (Tabela 52) bem estreita: de 49,2 (Paraná x BR 6) a $57 \mathrm{~cm} /$ planta (Bragg x BR 6), para os $\mathrm{F}_{2}{ }^{\prime} \mathrm{s}^{\prime}$ de 44,3 (Ivorá x BR 6) a 56,6 cm/planta (Paraná x Bragg) para os $F_{1 ' s}$; de $50,2(B r 6)$ a $58,3 \mathrm{~cm} /$ planta (Ivorá), para os parentais. Esses resultados relacionam-se aos de KASPAR et alii (1984), onde os autores encontraram uma satisfatória variação nas taxas de alongamentos das raízes.

Na Tabela 55, verifica-se que a heterose dos $F_{1 ' s}$ variou de $-18,27$ (Ivorá x BR 6) a 3,4\% (Paraná x Bragg), e as duas ünicas heteroses positivas foram pequenas em magnitudes e não significativas. A heterose dos $\mathrm{F}_{2}$ 's apresentou uma variação de $-18,2$ (Paraná x Bragg) a 21,2\% (Bragg $x$ BR 6); 66,6\% dos cruzamentos apresentou heterose negativa. A presença de heterose sugere diversidade genética entre os parentais. Esses resultados concordam com os obtidos para outros caracteres por CAMPOS (1979), KAW \& MENON (1979) e SEDOVA (1984).

A herdabilidade no sentido amplo (Tabela 55) variou de 22,8 (Paraná x Ivorá) a 76,4\% (Bragg x BR 6), indicando a possibilidade de progresso com seleção, principalmente para os cruzamentos Bragg x BR 6, Ivorá x BR 6 e Paraná $x$ BR 6 . 


\section{d. Comprimento da parte aérea (CPA)}

Os resultados da análise de variância (Tabela 51) demonstram que houve efeito significativo entre os genôtipos; todavia, diferenças significativas ocorreram apenas entre as testemunhas. Embora só tenha havido efeito altamente significativo para as testemunhas, o comportamento médio dos genótipos (Tabela 52) mostra que, pelo menos dois cruzamentos em $\mathrm{F}_{2}{ }^{\prime} \mathrm{s}$ - Paraná x Ivorá $(70,4 \mathrm{~cm} / \mathrm{planta})$ e Paraná x BR $6(67 \mathrm{~cm} /$ planta) - apresentaram comportamento médio superior à média das testemunhas $(66 \mathrm{~cm} /$ planta). Para os $\mathrm{F}_{1}$ 's' apenas Paraná x Bragg, apresentou comportamento igual à média das testemunhas. Resultados semelhantes, para a altura da planta, foram obtidos por ALA \& GAMOLIN (1987), RAJPUT et alii (1987), SARMAH et alii (1984) e WILCOX \& SEDIYAMA (1981).

A Tabela 56, apresenta as estimativas de parâmetros genotípicos dos $\mathrm{F}_{1}{ }^{\prime} \mathrm{s}^{\prime}$ onde constata-se que a heterose variou de $-11,93$ (Paraná x BR 6) à 14,35q (Paraná x Bragg). Além disso, os $\mathrm{F}_{1} \mathrm{~s}^{\prime}$ Paraná $\mathrm{x}$ Bragg e Ivorá x Bragg, apresentaram heterobeltiose de 7,7 a 11,28 , respectivamente. Nos $F_{2}{ }^{\prime} s^{\prime}$ a heterose variou de 8,3 (Ivoráx Bragg) à 39,1\% (Paraná $x$ Ivorá). Além disso, todos os $\mathrm{F}_{2}{ }^{\prime} \mathrm{s}^{\prime}$ revelaram heterobeltiose, que variou de 2,1 (Ivorá x Bragg) à 14,8\% (Paraná $x$ Ivorá). Resultados semelhantes foram obtidos por CAMPOS (1979), CHAUDHARY \& SING (1974), CHAUHAN \& SINGH (1982), KUNTA et alii (1985), SEDOVA (1984), WENTZ \& STEWART (1924). A presença de heterose e heterobeltiose indica divergência genética entre os parentais; como consequência,espera-se que ocorra maior variabilidade nas gerações segregantes (mais avançadas), o que possibilitaria o emprego de seleção. 
A variāncia dentro de $\mathrm{F}_{2}$ 's apresentou variação de 2183 (Bragg x BR 6) à 4270 (Paraná x BR 6) (cm/planta) ${ }^{2}$, demonstrando a existência de variabilidade nesses cruzamentos.

As magnitudes das herdabilidades no sentido amplo (Tabela 56) variaram de 48,7 a 81,3\%, indicando uma satisfatória possibilidade de transmissibilidade e/ou manutenção desse comportamento nas gerações seguintes, principalmente, para Paraná $x$ BR $6\left(h_{(A)}^{2}(A)=81,3 \%\right)$, Paraná $x$ Bragg $\left(\mathrm{h}_{(\mathrm{A})}^{2}=79,9 \%\right)$, Bragg $\mathrm{x}$ BR $6\left(\mathrm{~h}_{(\mathrm{A})}^{2}=74,6 \%\right)$ e Ivorá $\mathrm{x}$ BR 6 $\left(h^{2}(A)=65 \%\right)$. Esses resultados concordam com os obtidos por BELIC (1986), RAJPUT et alii (1987) e SISSON et alii (1976) .

\subsubsection{Correlações fenotipica $\left(r_{F}\right)$, genotipica $\left(r_{G}\right)$ e ambiental $\left(r_{E}\right)$}

As estimativas dos coeficientes de correlação fenotipica, genotipica e ambiental entre os quatro caracteres avaliados nos $\mathrm{F}_{2}{ }^{\prime} \mathrm{s}^{\prime}$ são apresentadas na Tabela 57. Nota -se uma certa similaridade em magnitude em sinal, entre as correlações fenotípica e genotipica, com exceção da correlação entre CRP e CPA $\left(r_{F}=-0,257\right.$ e $\left.r_{G}=-0,643\right)$.

Correlações genotipicas altas foram estimadas entre os caracteres PSR e PSA $(0,980)$, PSR e CRP $(0,786)$, PSA e $\operatorname{CRP}(0,618)$ e CRP e CPA $(-0,643)$. Tais resultados são relativamente semelhantes àqueles obtidos com linhagens homozigóticas; resultados relativamente divergentes envolveram a correlação CRP e CPA que teve tendência de permanecer próxima de zero nos genótipos precoces, semi-precoces e semi-tardios, mas alcançou valor intermediário negativo para os genótipos tardios. 
Em relação às correlações ambientais, às estimativas dos genótipos segregantes mostraram tendência de ser superiores às respectivas estimativas obtidas para os genótipos homozigóticos precoces, semi-precoces, semi-tardios e tardios. Tanto para genótipos segregantes quanto para genótipos homozigóticos, a correlação ambiental mais forte ocorreu entre os caracteres PSR e PSA, indicando que O ambiente influi de maneira semelhante estes dois caracteres.

\subsubsection{Análise dialélica de Griffing}

A análise de variância para os quatro parentais e os seis $F_{2}{ }^{\prime} s^{\prime}$ com desdobramento da soma de quadrados de genótipos em capacidade geral de combinação (CGC) e capacidade específica de combinação (CEC) para cada um dos caracteres avaliados, encontra-se na Tabela 58. Detectou-se efeito significativo para a capacidade geral de combinação somente para o caráter CPA. Para capacidade específica de combinação, houve efeitos significativos para PSR, IPA e PSA. O caráter CRP não apresentou nem CGC e nem CEC significativas.

SPRAGUE \& TATUM (1942) e VENCOVSKY (1987), COmentam que quando se tem uma baixa estimativa de CGC (positiva ou negativa), o valor da capacidade geral de combinação parental, não difere muito da média geral dos cruzamentos. Analogamente, quando se tem altas estimativas de CGC (positivas ou negativas), o parental em questão é superior ou inferior aos demais parentais incluídos no dialelo. Por outro lado, estimativas negativas da capacidade especifica de combinação, ocorrem quando os dois parentais forem semelhantes ou de pouca divergência genética, isto ê, tiveram altas ou baixas frẹquencias alélicas nos mesmos locos. 
Com relação aos efeitos da capacidade geral de combinação (Tabela 59), os parentais mostraram divergência genética nos caracteres CRP e CPA. Para CRP, 'Ivorá' apresentou valor positivo relativamente alto $\left(\hat{g}_{i}=1,8769\right)$ e 'BR 6' mostrou valor negativo relativamente alto $\quad\left(\hat{g}_{i}=\right.$ -1,2704). Para CPA, 'Paraná' teve valor positivo alto $\left(\bar{g}_{\dot{i}}=\right.$ $2,9439)$ e 'Bragg' apresentou valor negativo alto $\quad\left(\bar{g}_{i}=\right.$ -2,4022). Dessa maneira, 'Ivorá' possui genes para aumentar CRP e 'Paraná' contém genes para aumentar CPA. Análises semelhantes foram feitas para altura da planta e outros caracteres em soja (LEFFEL \& WEISS, 1958; FREIRE FILHO, 1988).

Com base nas estimativas de $s_{i j}$ da Tabela 59, pode-se considerar que alguns cruzamentos apresentaram complementação gênica mais favorável que os demais cruzamentos: Ivorá x BR 6 para PSR; Ivorá x Bragg e Ivorá x BR 6 para PSA; Bragg x BR 6 para CRP; Paraná x Ivorá para CPA.

\subsubsection{Análise dialélica de Hayman}

Os parâmetros estimados na análise dialélica de Hayman encontram-se na Tabela 60. Com base no erro padrão associado à estimativa do parâmetro estabelece-se o intervalo de confiança; se este intervalo inclui o valor zero, a estimativa do parâmetro é considerada nula; se o intervalo não inclui o zero, a magnitude da estimativa é considerada dfierente de zero, com uma probabilidade aproximada de $67 \%$ ( \pm um desvio padrão). Utilizando este critério, verifica-se na Tabela 60 que houve evidências de dominância gênica $\left(\hat{H}_{1} \neq\right.$ 0) controlando a herança dos caracteres PSA, CRP e CPA; apenas o caráter PSR mostrou evidências de aditividade $(\tilde{D} \neq 0)$. Com o auxilio do intervalo de confiança, as estimativas de grau médiọ de dominância $\left(\hat{H}_{1} / \tilde{D}\right)^{1 / 2}$ seriam: 
a. muito pequena (tendendo a zero) para PSR, indicando aditividade no controle genético do PSR;

b. maiores do que a unidade, indicando sobredominância gênica em PSA, CRP e CPA; no caso específico de PSA, a estimativa de $\left(\hat{H}_{1} / \tilde{D}\right)^{1 / 2}$ foi muito grande (tendendo ao infinitol.

As estimativas de herdabilidade no sentido restrito $\left(\mathrm{h}_{\mathrm{r}}^{2}\right)$ foram equivalentes a 0,57 (PSR), 0,28 (PSA), 0,18 (CRP) e 0,36 $(\mathrm{CPA})$. As magnitudes destas estimativas estão dentro dos limites esperados com base nas estimativas anteriormente discutidas para herdabilidade no sentido amplo. Realmente, houve uma tendência das herdabilidades no sentido restrito serem inferiores às herdabilidades no sentido amplo; apenas PSR não se enquadrou perfeitamente nesta tendência. A literatura dispõe de pouca informação sobre os genótipos do sistema radicular em soja. O CPA pode ser comparado, com as devidas restrições, à altura da planta adulta; para este carāter, BHATADE et alii (1977) obtiveram estimativa negativa para ' $F$ ' e herdabilidade $(0,45)$ com magnitude próxima da encontrada para CPA nesta pesquisa. Os alelos dominantes e recessivos parecem terem frequências semelhantes $(\hat{F}=0)$ no conjunto gênico formado pelos parentais e seus cruzamentos; apenas nos caracteres PSA e CPA haveria necessidade de utilizar intervalos de dois desvios padrões (95\%) para que o valor zero fosse incluído no mesmo.

\subsection{Sugestões para aprimorar a eficiência da avaliação do sistema radicular}

No item 4.4.3. (correlações intra-classes para genótipos tardios) foram comentadas algumas das possiveis razões para a Falta de correlação de caracteres avaliados em 
plantas imaturas cultivadas em telado com caracteres avaliados em plantas adultas cultivadas no campo. Algumas sugestões podem ser apresentadas para aprimorar a eficiência da avaliação de caracteres do sistema radicular, principalmente para obter melhor controle experimental dos fatores ambientais e, consequentemente, alcançar estimativas mais precisas dos parâmetros genéticos. Listas sugestões são as seguintes:

a. utilizar sacos plásticos com profundidade superior a : 50 $\mathrm{Cm}$;

b. fazer um experimento em branco para estabelecer quao o volume de água para atingir a capacidade de campo, de maneira a se poder irrigar os sacos com volume igual e constante;

c. só avaliar quando a areia estiver seca lpara evitar que grãos de areia fiquem aderidos nas raizes por ocasião da avaliação) utilizando peneira de malha fina (para evitar perdas de fragmentos de raíses);

d. quando não se tratar de teste de competição, manter uma planta por saco, para evitar o entrelaçamento de raizes que normalmente ocorre quando se emprega mais de uma plan ta;

e. seria recomendável testar se inoculações das plantas jovens com Bradyrhjzobium e/ou Micorriza, poderia modifi-car as correlações entre caracteres avaliados em plantas jovens, cultivadas em vasos (sasos plástico) e plantas adultas cultivadas em campo. 


\section{CONCLUSÕES}

As análises estatístico-genéticas de genótipos homozigóticos pertencentes a quatro grupos de maturação e de um dialelo $4 \times 4\left(F_{1}\right.$ e $\left.F_{2}\right)$, avaliados para quatro caracteres de plantas jovens cultivadas em telado - peso seco de raizes (PSR) e da parte aérea (PSA), comprimento da raiz principal (CRP) e da parte aérea (CPA) - e para dois caracteres de plantas maturas de soja cultivadas em campo (três locais) - produtividade de grãos e acamamento - permitiram as seguintes conclusões:

a. Existiu variabilidade genética tanto entre genótipos homozigóticos quanto entre plantas da geração $F_{2}$ para todos os caracteres.

b. A quantidade de variabilidade genética foi diferente nos quatro grupos de maturação: para PSR, a quantidade de variabilidade foi razoável apenas nos genótipos tardios; no PSA existiu variabilidade razoável nos quatro grupos de maturação; O CRP mostrou gradiente decrescente de variabilidade dos genótipos precoces para os semi-precoces, semi-tardios e tardios; O CPA exibiu nível alto de variabiIidade entre os genótipos precoces e niveis intermediários entre os genótipos semi-precoces, semi-tardios e tardios; a produtividade teve níveis razoáveis de variabili- 
dade em todos os grupos de maturação e nos três locais, mas a magnitude da variabilidade foi superior na ESALQ e em Sertãozinho e inferior em Anhembi; o acamamento mostrou altos niveis de variabilidade em todos os grupos de maturação e nos três locais.

c. Interação genótipos $x$ locais existiu apenas nos genótipos semi-precoces para produtividade e nos genótipos semi-precoces e semi-tardios para acamamento.

d. A magnitude da heterose variou com o caráter, com o cruzamento e com a geração $\left(\mathrm{F}_{1}\right.$ ou $\left.\mathrm{F}_{2}\right)$; os valores máximos foram: 30\% $\left(F_{1}\right)$ e 63 $\left(F_{2}\right)$ para PSR no cruzamento Ivorá $x$ $\mathrm{BR}$ 6; $23 \%\left(\mathrm{~F}_{1}\right.$ de Paraná $\mathrm{x}$ Bragg) e 38\% $\left(\mathrm{F}_{2}\right.$ de Ivorá $\mathrm{x}$ $\mathrm{BR} 6)$ para PSA; 3,4을 $\left(\mathrm{F}_{1}\right.$ de Paraná $\mathrm{x}$ Bragg) e $21 \%\left(\mathrm{~F}_{2}\right.$ de Bragg $x$ BR 6) para CRP; $14 \%\left(F_{1}\right.$ de Paraná $x$ Bragg) e 39\% $\left(F_{2}\right.$ de Paraná $x$ Ivorá) para CPA.

e. As correlações genotípicas mostraram-se superiores às fenotipicas e às ambientais; correlações genotípicas altas para os genótipos homozigóticos dos quatro grupos de maturação e para a geração $F_{2}$ ocorreram entre os caracteres PSR e PSA, PSR e CRP; os caracteres CRP e PSA exibiram correlações genotípica relativamente alta em todos os tipos de genótipos, com exceção dos semi-tardios; os caracteres CRP e CPA mostraram correlações genotípicas relativamente altas apenas nos genótipos semi-tardios e na geração $\mathrm{F}_{2}$; as correlações genotipicas entre produtividade e acamamento foram muito variáveis (de -0,79 para genótipos semi-tardios em Sertãozinho até 0,99 para genótipo tardio na ESALQ); as correlações de caracteres de plantas jovens avaliadas no telado com caracteres de plantas maturas avaliadas no campo foram próximas de zero, alcançando vạlor máximo de 0,25. 
f. A anālise de Griffing revelou diferenças na capacidade geral de combinação apenas para o caráter CPA; diferenças na capacidade especifica de combinação ocorreram nos caracteres PSR, CPA e. PSA; 'Ivorá' mostrou possuir a maioria dos genes para aumentar CRP e 'Paraná' para aumentar CPA; os melhores niveis de complementação gênica ocorreram nos cruzamentos: Ivorá x BR 6 (PSR e PSA), Ivorá x Bragg (PSA), Bragg x BR 6 (CRP), Paraná x Ivorá (CPA).

g. A análise de Hayman indicou aditividade em PSR e dominância gênica em PSA, CRP e CPA; as estimativas de herdabilidade no sentido restrito variaram com os caracteres: 0,18 (CRP), 0,28 (PSA), 0,36 (CPA), 0,57 (PSR). 


\section{REFERENCIAS BIBLIOGRÁFICAS}

ALA, A. YA. \& GAMOLIN, A.A. Inheritance of stem length and number of nodes on the main stem in soybean in the $\mathrm{F}_{2}$ of Glycine max $x$ Glycine soja. Nauchnoteklinicheskic Byulleten Sibirskogo otdelemya Vaskhnil, Romania, 37: 3-9, 1985. Apud: Plant Breed. Abst., Cambridge, 57(10): 9391, 1987. (Resumo)

ALLARD, R.W. Principios do melhoramento genético das plantas. São Paulo, Edgard Blucher, 1971. 381 p.

ANAND, S.C. \& TORRIE, J.H. Heritability of yield and other traits and interrelationships among traits in the $\mathrm{F}_{3}$ and $\mathrm{F}_{4}$ generations of three soybean crosses. Crop Sci., Madison, $\underline{3}(6)$ : 508-11, 1963 .

ANDREW, R.H. A technique for measuring root volume in vivo. Crop. Sci., Madison, 6: 384-6, 1966.

BARTLEY, B.G. \& WEBER, C.R. Heritable and nonheritable relationships and variability of agronomic characters in sucessive generations of soybean crosses. Agron. J., Madison, $\underline{44}(5): 487-93,1952$. 
BELIC, B.; JOCKOVIC, D.; HRUSTIC, M. The heritability of quantitative characters in soybean (Glycine max (L.) Merrill). Arhiv za Poljoprivredne Nauke, Iuguslávia, 46 (2): 97-113, 1985. Apud: Plant Breed. Abst., Cambridge, $\underline{56}$ (12) : 11224, 1986. (Resumo).

BHATADE, S.S.; SINGH, C.B.; TIWARI, A.S. Diallel analysis of yield and its components in soybean. Indian J. Agric. Sci., New Delhi, $\underline{47}(7): 322-4,1977$.

BOHM, W.; MADUAKOR, H.; TAYLOR, H.M. Comparison of five methods for characterizing soybean rooting density and development. Agron. J., Madison, 69: 415-9, 1977.

BROWN, D.A. Characterizing soybean root growth and distribution. Arkansas Farm Research, Arkansas, 33 (1): 3,1984 .

BURTON, G.W. Quantitative inheritance in grasses. In: INTERNATIONAL GRASSLAND CONGRESS, 6., 1952. Proceedings, $\mathrm{v} .1, \mathrm{p} .277-83$.

CAMACHO, L.H. Genetics variances and heritability of vegetative and reprodutive characters of soy bean (Glycine max (L.) Merr.). Revista Instituto Colombiano Agropecuário, Colombia, 9 (3): 345-52, 1974. Apud: $\underline{\text { Plant Breed. }}$ Abst., Cambridge, $47(2)$ : 1816, 1977. (Resumo).

CAMPOS, L.A.C. Estudo da heterose, da herdabilidade e de correlações de algumas características agronômicas em cru zamentos de soja (Glycine mas (L.) Merrill). Viçosa, 1979. 76 p. (M.S. - Universidade Federal de Viçosa). 
CARRASCO, H.D. \& GONZALES, J.P.L. Correlaciones fenotípicas en soya y su importancia en la seleccion para rendimiento. Ciências de la Agricultura, La Habana, 24: 99-103, 1985.

CHAUDHARY, B.D. Studies on combining ability analysis in soybean. Crop Improvement, Hissar, 12(2): 151-4, 1985. Apud: plant Breeding Abstract, Cambridge, 56 (7): 6322, 1986. (Resumo).

CHAUDHARY, D.N. \& SING, B.B. Heterosis in soybean. Indian J. Genet. Plant Breed., New Delhi, 34(1). 69-74, 1974.

CHAUHAN, V.S. \& SINGH, B.B. Heterosis and genetic variability in relation to genetic divergence in soybean. Ind. J. Plant. Breed., New Delhi, 42(3): 324-8, 1982.

CHAUHAN, V.S. \& SINGH, B.B. Genetic variability and heritability in soybean. Indian J. Agric. Sci., New Delhi, $\underline{54}(4): 273-6,1984$.

CHEN, H.H. Genetic analysis of heterosis in soybean. Chinese Oil Crops, China, $\underline{2}: 1-8,1982$. Apud: Plant Breed. Abst., Cambridge, 53(9): 7724, 1983. (Resumo)

COOPER, R.L. Influence of early lodging on yield of soybean (Glycine max (L.) Merr.). Agron. J., Madison, 63(3):449$-50,1971$.

DESTRO, D.; SEDIYAMA, T.; SILVA, J.C.; SEDIYAMA, C.S.; THIEBAUT, T.L. Estimativas de herdabilidade de alguns caracteres, em dois cruzamentos de soja. Pesq. Agropec. Bras., Brasilia, 22(3): 291-304, 1987 . 
EGLI, D.B.; GUFFY, R.D.; LEGGETT, J.E. Partitioning of assimilate between vegetative and reproductive growth in soybean. Agron. J., Madison, 77(6): 917-22, 1985.

FALCONER, D.D. Introduction to quantitative genetics. 2 . ed. London, Longman, 1981. 340 p.

FARIAS NETO, J.T. de. Comportamento e variabilidade de genótipos de soja (Glycine max (L.) Merrill) em cultivos de verão e inverno. Piracicaba, 1987. 87 p. (Mestrado Escola Superior de Agricultura "Luiz de Queiroz"/USP) .

FERREIRA, P.E. On Jinks-Hayman's analysis of half dialels.

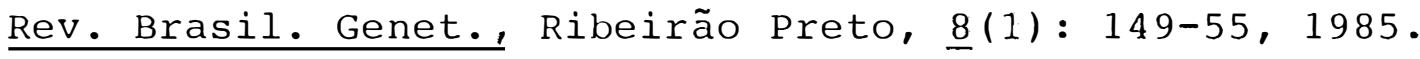

FOLEY, T.C.; ORF, J.H.; LAMBERTS, J.W. Performance of related determinate and indeterminate soybean lines. Crop Sci., Madison, 26 (1): 5-8, 1986 .

FONSECA, T.C. Estimação de parâmetros visando a seleção de híbridos artificiais de amoreira (Morus alba L.). Piraci caba, 1978. 51 p. (Mestrado - Escola Superior de Agricultura "Luiz de Queiroz"/USP).

FREIRE FILHO, F.R. Análise genética de um dialelo entre genótipos precoces de soja [Glycine max (L.) Merrill]. Piracicaba, 1988. 224 p. (Doutorado - Escola Superior de Agricultura "Luiz de Queiroz"/USP) .

GARLAND, M.L. \& FEHR, W.R. Selection for agronomic characters in hill and row plots of soybeans. Crop Sci., Madison, 21 (4): 591-5, 1981 . 
GILIOLI, J.L.; SEDIYAMA, T.; SILVA, J.C.; THIÉBAUT, J.T.L.; REIS, M.C. Estimativas de herdabilidade e de correlações fenotipicas para alguns caracteres, em quatro mutantes naturais em soja. Pesq. Agropec. Bras., Brasilia, 15 (4): $379-84,1980$.

GOMES, F.P. Curso de estatistica experimental. 12. ed. São Paulo, Nobel, 1987. 465 p.

GREEN, D.E. \& PINNELL, E.L. Inheritance of soybean seed quality; I. Heritability of laboratory germination and field emergence. Crop Sci., Madison, 8(1):5-11, 1968.

GREDER, R.R.; ORF, J.H.; LAMBERT, J.W. Estimates of variation and heritability for nodule mass and recovery of Rhizobium japonicum strain 110. Soybean Genetics News. -letter, Ames, 10: 55-9, 1983.

GREEN, D.E.; LUEDDERS, V.D.; MORAGHAN, B.J. Heritability and advance from selection for six soybean seed quality characters. Crop Sci., Madison, 11(4): 531-3, 1971 .

GRIFFING, B. Concept of generaland specific combining ability in relation to diallel-crossing systems. Aust. J. Biol. Sci., Melbourne, 9: 462-93, 1956.

GUPTA, V.P.; GARG, I.K.; RANA, N.D.; SINGH, J.M. Variation and heritability for leaf and root characteristics in soybean, across locations. Soybean Genetics Newsletter, Ames, 9: $71-4,1982$. 
GYUROVA, M. \& ILCHEVA, E. Heigh in soybean plants as on index of agronomic and meteorological conditions for seed yield development. Nauchm Trudve Vissh Shelskostopanski. Institutut "Vasilkolarov", Bulgaria, 27(4): 111-25, 1982. Apud: Plant Breed. Abst., Cambridge, 55(9): 7407, 1985. (Resumo).

HANSON, W.D. \& WEBER, C.R. Analysis of genetic variability from generations of plant-progeny lines in soybeans. Crop Sci., Madison, $\underline{2}(1) .63-7,1962$.

HARPER, J.L. \& OGODEN, J. The reprodutive strategy of higher plants; I. The concept of strategy with special reference to Senecio vulgaris L. Journal of Ecology, London, 58: 681-98, 1970.

HARTWIG, E.E. \& EDWARDS, C.J. Effect of morphological characteristics upon seed yield in soybeans. Agron. J., Madison, $\underline{62}(1): 64-5,1970$.

HAYMAN, B.I. The theory and analysis of diallel crosses. Genetics, Baltimore, 39(6): 789-809, 1954 .

HAYMAN, B.I. The theory and analysis of diallel crosses: II. Genetics, Austin, 43 (13): 63-85, 1958.

JOHNSON, H.W.; ROBINSON, H.F. \& COMSTOCK, R.E. Estimate of genetic and environmental variability in soybeans. Agron. J., Madison, $\underline{47}(7): 314-8,1955 \mathrm{a}$.

JOHNSON, H.W.; ROBINSON, H.F.; COMSTOCK, R.E. Genotypic and phenotypic correlation in soybean and their implications in selection. Agron. J., Madison, 47(10): $477-83, .1955 b$. 
KASPAR, T.C.; STANLEY, C.D.; TAYLOR, H.M. Soybean root growth during the reprodutive stages of development. Agron. J., Madison, 70: 1105-7, 1978.

KASPAR, T.C.; TAYLOR, H.M.; SHIBLES, R.M. Taproot-elongation rates of soybean cultivars in the glasshouse and their relation of field rooting depth. Crop Sci.,

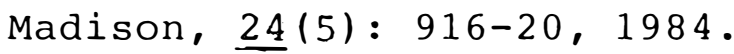

KAW, R.N. \& MENON, P.M. Heterosis in a ten-parent diallel cross in soybean. Indian J. Agric. Sci., New Delhi, 49 (5) : $322-4,1979$.

KELLER, F.R.; SOLDATI, A.; DIATHINI, F. Study on the technique of crossing as well as on the genetic behaviour of quantitative characters of soybean. Soybean Genetics. Newsletter, Ames, 5: 79-90, 1978.

KEMPTHORNE, O. An introduction to genetic statistics. Ames, Iowa State University Press, 1973. $454 \mathrm{p}$.

KEMPTHORNE, O. \& CURNOW, R.N. The partial diallel cross. Biometrics, Washington, 17(2): 229-50, 1961 .

KEY, J.M. Methods of root studies for crop improvement. In: PLANT roots. Ames, Iowa State University, 1980 . p. 1-15.

KUNTA, T.; EDWARDS, L.H.; MCNEW, R.W.; DINKINS, R. Heterosis performance and combining ability in soybeans. Soybean Genetics Newsletter, Ames, 13: 97-9, 1985.

KWON, S.H. \& TORRIF, J.H. Heritability of and interrelationships among traits of two soybean populations. Crop Sci., Madison, $\underline{4}(2): 196-8,1964$. 
LEFFFL, R.C. \& WEISS, M.G. Analysis of diallel crosses among ten varieties of soybeans. Agron. J., Madison, $\underline{50}$ (4) : 528-34, 1958 .

LESHCHENKO, A.K. \& MIKHAILOV, V.G. Combining ability of varieties and lines of soya bean. Nokotor. vopr. selekt sii i biol. soi., Blagoveshchensk, USSR. Apud Plant. Breeding Abstract, Cambridge, 47(6): 6035, 1977. (Resumo)

LUEDDERS, V.D.; DUCLOS, L.A.; MATSON, A.モ. Bulk, pedigree, and early geration testing breeding methods compared in soybeans. Crop Sci., Madison, 13(3): 363-4, 1973 .

MAHMUD, I. \& KRAMER, H.H. Segregation for yield, height, and maturity following a soybean cross. Agron. J., Madison, $43(12): 605-9,1951$.

MARIN, A. The inheritance of some quantitative characters in soya bean and the existence of correlation between them. Biuletyn Instytutu Hodowli i Aklimatyzacji Roslin, Romama, 128/9: 59-62, 1975. Apud: Plant Breed. Abst., Cambridge, $\underline{50}(5): 4590,1980$. (Resumo)

MARTIN, R.J. \& WILCOX, J.R. Heritability of lowest pod height in soybeans. Crop Sci., Madison, 13(2): 201-3, 1973 .

MARTINS, P.S. \& VFLLO, N.A. Performance and variability of agronomic characters in populations of stylosantes guianensis (Aubl.) Sw. In: INTERNATIONAL GRASSLAND CONGRESS, 14., Kentuchy, 1981. Proceedings, s.n.t. p. 196-8. 
MAYAKY, W.C.; TEARE, I.D.; STONF, L.R. TOp and root growth of irrigated and non-irrigated soybeans. Crop Sci., Madison, 16: 92-4, 1976 .

MIKU, G. Heritability of characters in soya bean hybrids. Genetika sektsia i semenovodstovo s.-kh. rastenii. Kishinev, Moldavian, S.S.R., 31-8, 1977. Apud: Plant Breed. Abst., Cambridge, 50 (3): 2555, 1980. (Resumo).

MIRANDA, J.F.C. de. Análise genética de um cruzamento dialélico em pimentão (Capsicum annuum L.). Piracicaba, 1987. 159 p. (Doutorado - Escola Superior de Agricultura "Luiz de Queiroz"/USP).

MITCHELL, R.L. \& RUSSEL, W.J. Root development and rooting patterns of soybeans [Glycine max (L.) Merrill] evaluated under field conditions. Agron. J., Madison, 63; 316-6, 1971 .

MODF, J.C. \& ROBINSON, H.F. Pleiotropism and the genetic variance and covariance. Biometrics, Washington, 15:518$-37,1959$.

MOLL, R.H. \& STUBER, C.W. Quantitative genetics; empirical results relevant to plant breeding. Adv. Agron., New York, 26: 277-313, 1974 .

MONTEIRO, W.R. Estudo da variabilidade e conclusão entre caracteres agronômicos em populações de Centrosema pubescens Benth. Piracicaba, 1980. 70 p. (Mestrado - Escola Superior de Agricultura "Luiz de Queiroz"/USP) . 
MULLFR, L. Morfologia, anatomia e desenvolvimento. In: MIYASAKA, S. \& MEDINA, J.C., ed. A soja no Brasil. Campinas, ITAL, 1981. p. 73-108.

NEWMAN, F.I. A methods of estimating the total lenght of root in a sample. J.Appl. Fcol., Oxford, 3: 139-45, 1966 .

PASCHAL, F.H. \& WILCOX, J.R. Heterosis and combining ability in exotic soybean germplasm. Crop Sci., Madison, 15 (3) : 344-9, 1975 .

RAJPUT, M.A.; SARWAR, G.; TAHIR, K.H. Variability for some quantitative traits in soybean. Soybean Genetics Newsletter, Ames, 14: 113-6, 1987.

RANA, N.D.: KALIA; R.K.; GUPTA, V.P. Correlation among seed yield seel quality and nutricional traits in soybean. Soybean Genetics Newsletter, Ames, 9: 81-5, 1982 .

RANGEL, P.H.N. Correlações fenotípicas, genotípicas, de ambiente e coeficientes de trilha, em variedades de arroz (Oryza sativa J.). Viçosa, 1979. 44 p. (M.S. - Universidade Federal de Viçosa).

RANZANI, G.; FREIRE, O.; KINJO, T. Carta de solos do municipio de Piracicaba. Piracicaba, Centro de Fstudos de Solos/ESALQ/USP, 1966. 85 p.

RAPER JUNIOR, C.D. \& BARBER, S.A. Rooting systems of soybeans. I. Differences in root morphology among varieties. Agron. J., Madison, 62(6): 581-4, 1970 . 
REICOSKY, D.C.; MILLINGTON, R.J.; PETERS, D.B. A comparison of three methods for estimating root length. Agron. J., Madison, 62: 451-3, 1970 .

ROBINSON, H.F.; COMSTOCK, R.F.; HARVEY, P.H. Genotypic and phenotypic correlations in corn and their implications in selection. Agron. J., Madison, 43(6): 282-7, 1951 .

SABBOUH, M.Y. \& EDWARDS, L.H. Combining ability for seed protein and oil content in soybeans. Soybean Genetics, Newsletter, Ames, 12: 99-100, 1985. .

SARMAH, S.C.; KALITA, M.M.; KAKATI, N.N. Effect of dates of planting on five soybean varieties. Soybean Genetics Newsletter, Ames, 11: 34-7, 1984.

SARRUGF, J.R. Soluções nutritivas. Suma Phytopathologica, Piracicaba, 1(1): 231-3, 1975 .

SATTERTHWAITE, F.F. An approximate distribuition of estimates of variance components. Biometrics, Washington, $\underline{2}(1): 110-4,1946$.

SCHUURMAN, J.J. \& GOFDFWAAGEN, M.A.J. Methods for the examination of root systems and roots. 2. ed. Wageningen, Centre for Agricultural Publishing and Documentation, 1971. $86 \mathrm{p}$.

SFDOVA, T.S. Yield and its variation in intervarietal $F_{1}$ and $\mathrm{F}_{2}$ hybrid populations of soybean. Sib. vestn. s-kl nanki, Russia, $\underline{6}: 16-21,1981$. Apud: Plant Breed, Abst., Cambridge, 54 (11): 8566, 1984. (Resumo). 
SILVA, A.C. Avaliação de milho (zea mays L.) para eficiēncia ao fósforo usando diferentes doses de adubação fosfatada em solos com alumínio tóxico. Piracicaba, 1980. 54 p. (Mestrado - Escola Superior de Agricultura "Luiz de Queiroz"/USP) •

SINGH, C.B.; DALAL, M.A.; SINGH, S.P. Genetic analysis of field germination in soybean (Glycine max (L.) Merrill). Theor. Appl. Genet., Berlim, 52(4): 165-9, 1978 .

SISSON, V.A.; MILLER, P.A.; CAMPBELL, W.V.; DUYN, J.W. Van. Evidence of inheritance of resistance to the Mexican bean in soybeans. Crop Sci., Madison, 16(6): 835-7, 1976.

SPRAGUE, G.F. \& TATUM, L.A. General vs specific combining ability in single crosses of corn. J. Amer. Soc. Agron., Madison, 34(10): 923-32, 1942 .

STEEL, R.G.D. \& TORRIE, J.H. Linear models and analysis of variance. In: STEEL, R.G.D. \& TORRIE, J.H., ed. Principles and procedures of statistics. 2. ed., New York, Mac Graw Hill, 1980a. cap. 9, p. 218-21.

STEEL, R.G.D. \& TORRIE, J.H. Somes uses of chi-square. In: STEEL, R.G.D. \& TORRIE, J.H., ed. Principles and procedures of statistics. 2. ed. New York, McGraw-Hill, 1980 b. cap. 20, p. 469-76.

TIAN, P.Z. Studies of root system ecotypes in soybean cultivars. Acta Agromica Sinica, China, 10(3):173-8,1575. Apud: Plant Breed Abst., Cambridge, 56(3):2360, 1986. ( Resumo) 
TRAGNAGO, J.L. Herdabilidades, correlações fenotípicas e ge. notípicas e ganhos genéticos de qualidade de sementes em soja (Glycine max (L.) Merrill). Viçosa, 1981. 74 p. (M.S. - Universidade Federal de Viçosa/UFV).

TOLEDO, J.F.F. de \& KIIHL, R.A.S. Métodos de anālise dialélica do modelo genético em controle das caracteristicas dias para a floração e número de folhas trifoliadas em so ja. Pesq. Agropec. Bras., Brasilia, 17(5): 745-55, 1982.

VELLO, N.A. Efeitos da introdução de germoplasma exótico so bre a produtividade e relações com a base genética das cultivares de soja [Glycine max (L.) Merrill]. Piracicaba, 1985. 91 p. (Livre-Docência - Escola Superior de Agricultura "Luiz de Queiroz"/USP).

VELLO, N.A. \& VENCOVSKY, R. Variâncias associadas as estima tivas de variâncais genéticas e coeficientes de herdabilí dade. Rel. Cient. Dept. Genet., Piracicaba, 8: 238-48, 1974 .

VENCOVSKY, R. Herança quantitativa. In: PETERNIANI, E. \& VIEGAS, G.P., ed. Melhoramento e produção do milho. Campinas, Fundação Cargill, 1987. v. 1, p. 137-214.

VERMA, V.D. \& RAM, H.H. Heritability estimates for seed quality traits in soybeans. Newsletter Genetics Soybean, Ames, 13: 67-70, 1986.

WEBER, C.R. \& FEHR, W.R. Seed yield losses from lodging and combine havesting in soybean. Agron. J., Madison, 58(3): $287-9,1966$. 
WFBER, C.R. \& MOORTHY, B.R. Heritable and nonheritable relationships and variability of oil content and agronomic characters in the $\mathrm{F}_{2}$ generation of soybean crosses. Agron. J., Madison, 44 (3): 202-9, 1952 .

WEBER, C.R.; EMPIG, L.T.; THORNE, J.C. Heterotic performance and combining ability of two-way $F_{1}$ soybean hydrids. Crop Sci., Madison, 10(2): 159-60, 1970 .

WEISS, M.G.; WEBER, C.R.; WILLIAMS, L.F.; PROBST, A.H. COrrelation of agronomic characters and temperature with seed with compositional characters in soybeans, as influence by variety and time planting. Agron. J., Madison, $\underline{44}(3)$ : $289-97,1952$.

WENTZ, J.B. \& STEWART, R.T. Hybrid vigor in soybeans. J. Amer. Soc. Agron., Madison, $16(7): 534-40,1924$.

WILCOX, J.R. \& SEDIYAMA, T. Interrelationships among height, lodging and yield in determinate and indeterminate soybean. Euphytica, Wageningen, 30(2): 323-6, 1981 .

WILCOX, J.R.; KHALAF, A.G.M.; BROSSMAN, G.D. Variability within and among $F_{1}$ families from diverge three-parent soybean crosses. Crop Sci., Madison, 24(6): 1055-8, 1984 .

WOODWORTH, C.M. Genetics of the soybean. J.Amer. Soc. Agron., Madison, 25(1): 36-51, 1933 . 
YAP, T.C. \& LEE, L.F. Performance and path coefficient analysis of soybeans under local conditions. Malaysian Agricultural Research, Malaya, $\underline{4}(2):$ 97-102, 1975. Apud Plant Breed. Abst., Cambridge, $47(5): 4827,1977$. (Resumo) . 
.101.

TABELAS 
TABELA 1. Relaçāo dos genótipos precoces e testemunhas con as respectivas identificaçōes.

\begin{tabular}{|c|c|c|c|c|c|}
\hline \multirow{2}{*}{$\begin{array}{l}\text { Geno- } \\
\text { tipos } \\
1\end{array}$} & Códigos & Identificaşão & $\begin{array}{l}\text { Genó- } \\
\text { tipos }\end{array}$ & Códigos & Identificaçāo \\
\hline & S 56 & Bed ford & 41 & S 363 & FT $81-2154$ \\
\hline 2 & S 63 & Bragg & 42 & S 386 & FT $81-2160$ \\
\hline 3 & S 223 & $\mathrm{BR}-2$ & 43 & S 369 & FT $81-2161$ \\
\hline 4 & S 130 & $S 225=B R-6$ & 44 & S 366 & FT $81-2164$ \\
\hline 5 & S 138 & Campos Gerais & 45 & S 371 & FT $81-2168$ \\
\hline 6 & S 140 & Coker 136 & 46 & S 382 & FT $81-2177$ \\
\hline 7 & S 60 & Coker 156 & 47 & S 377 & FT $81-2396$ \\
\hline 8 & S 55 & Essex & 48 & S 390 & FT $81-2690$ \\
\hline 9 & S 54 & Forrest & 49 & S 370 & FT 81-2694 \\
\hline 10 & S 221 & FT 4 & 50 & S 375 & FT $81-2699$ \\
\hline 11 & S 400 & FT $80-86$ & 51 & S 349 & FT $81-8105$ \\
\hline 12 & S 373 & FT 81-1295 & 52 & S 297 & GO $81-8491$ \\
\hline 13 & S 357 & FT $81-1797$ & 53 & S 157 & Hale 321 \\
\hline 14 & S 388 & FT 81-1799 & 54 & S 158 & Harrel \\
\hline 15 & S 378 & FT $81-1802$ & 55 & S 159 & Hill \\
\hline 16 & S 395 & FT $81-1804$ & 56 & S 160 & Hood \\
\hline 17 & S 383 & FT $81-1805$ & 57 & S 214 & IAS-1 \\
\hline 18 & S 381 & FT $81-1810$ & 58 & S 215 & IAS-2 \\
\hline 19 & S 351 & FT $81-1815$ & 59 & S $108-2$ & IAS -5 escura \\
\hline 20 & S 363 & $\mathrm{FT} 81-1821$ & 60 & S 165 & Ivorá \\
\hline 21 & S 360 & FT $81-1823$ & 61 & S 265 & Lancer \\
\hline 22 & S 394 & FT $81-1835$ & 62 & S 53 & NT $77-114$ \\
\hline 23 & S 364 & FI $81-1848$ & 63 & S 178 & Ogden \\
\hline 24 & S 380 & FT 81-1859 & 64 & S 180 & Palinet to \\
\hline 25 & S 361 & FT $81-1864$ & 65 & S 181 & Pampeira \\
\hline 26 & S 387 & FT $81-1865$ & 66 & S 196 & $P I-54-610$ \\
\hline 27 & S 354 & FT $81-1869$ & 67 & S 186 & Prata \\
\hline 28 & S 355 & FT $81-1878$ & 68 & S 290 & OC $73-18=$ Primavera \\
\hline 29 & S 392 & FT 81-2044 & 69 & S 191 & 'S-100' \\
\hline 30 & S 379 & FT $81-2047$ & 70 & S 292 & SOC 823 \\
\hline 31 & S 376 & FT $81-2050$ & 71 & S 256 & SOC $81-75$ \\
\hline 32 & S 353 & FT $81-2112$ & 72 & S 258 & SOC $81-79$ \\
\hline 33 & S 372 & FT $81-2115$ & 73 & S 259 & SOC $81-82$ \\
\hline 34 & S 389 & FT $81-21.27$ & 74 & S 260 & SOC $81-104$ \\
\hline 35 & S 359 & FT 81-21.32. & 75 & S 262 & SOC $81-109$ \\
\hline 36 & S 356 & FT $81-21.33$ & 76 & S 263 & SOC $81-110$ \\
\hline 37 & S 368 & FT $81-2134$ & 77 & S 264 & SOC $81-114$ \\
\hline 38 & S 352 & FT $81-2142$ & 78 & S 271 & SOC $81-130$ \\
\hline 39 & S 393 & FT $81-2148$ & 79 & S 272 & SOC $81-131$ \\
\hline 40 & S 391 & FT $81-2153$ & 80 & S 84 & TN 82-269 \\
\hline $\begin{array}{l}\text { Teste- } \\
\text { munhas }\end{array}$ & & & $\begin{array}{l}\text { Teste- } \\
\text { munhas }\end{array}$ & & \\
\hline $\mathrm{T}_{1}$ & S 99 & IAC- $11(\text { semi-tardio })^{1}$ & $\mathrm{~T}_{4}$ & S 108-1 & $\begin{array}{l}\text { IAS-5-clara } \\
\text { (precoce) }\end{array}$ \\
\hline $\mathrm{T}_{2}$ & S 100 & IAC-12 (semi-precoce $)^{1}$ & $\mathrm{~T}_{5}$ & S 255 & Paraná (precoce) \\
\hline $\mathrm{T}_{3}^{2}$ & S 102 & $\begin{array}{l}\text { IAC-Fosca rin } \\
(\text { precoce })^{1}\end{array}$ & $T_{6}^{3}$ & S 231 & Tropical $\left(\right.$ tardio $^{1}$ \\
\hline
\end{tabular}

\footnotetext{
1. Testemunhas comuns .
} 
TABELA 2. Relação dos genötipos semi-precoces e testemunhas com as respectivas identificaçōes.

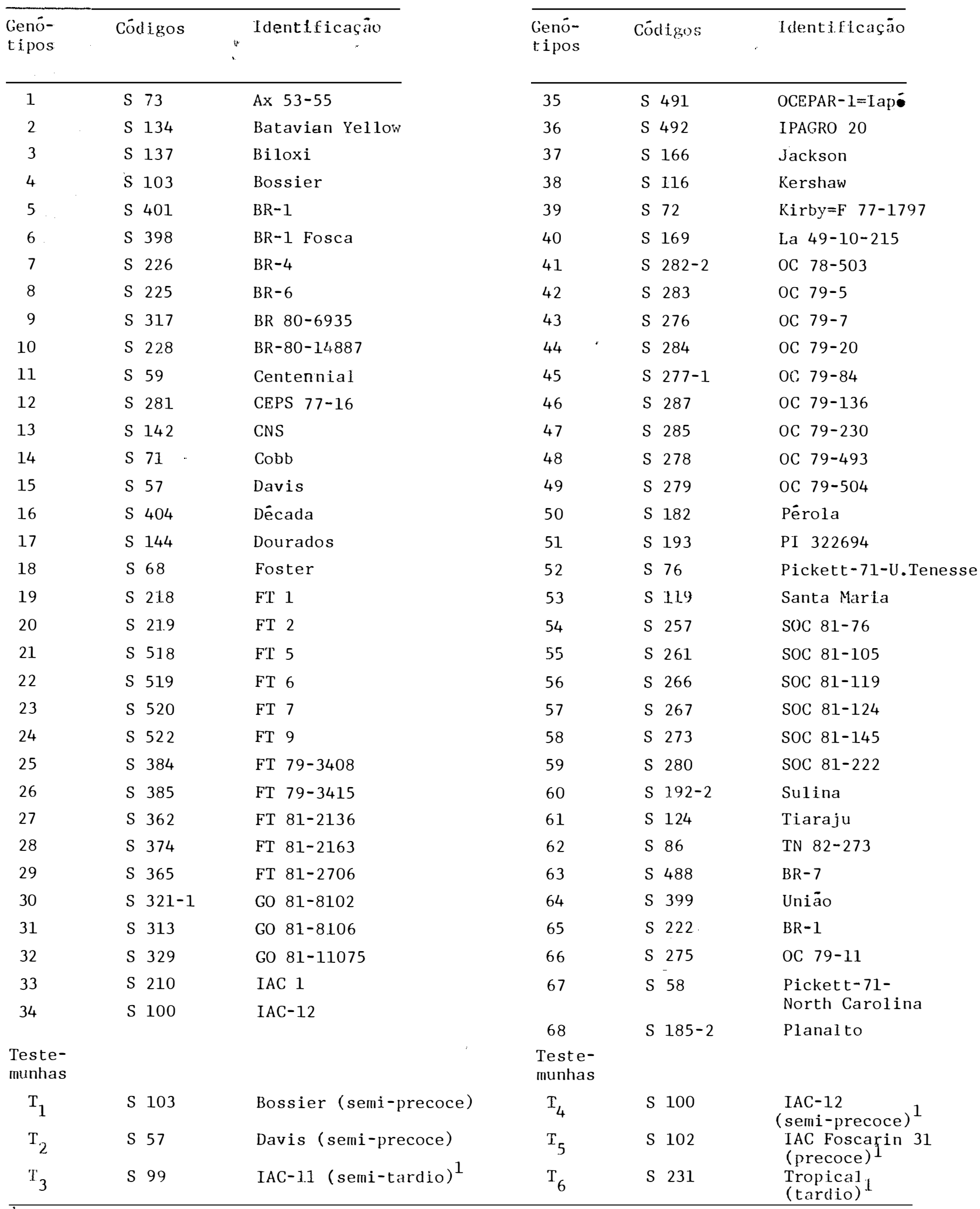

\footnotetext{
I. Testernunhas comuns.
} 
TABẼa 3. Relaçāo dos genōtipos semi-tardios e testemunhas com as respectivas identificaşōes.

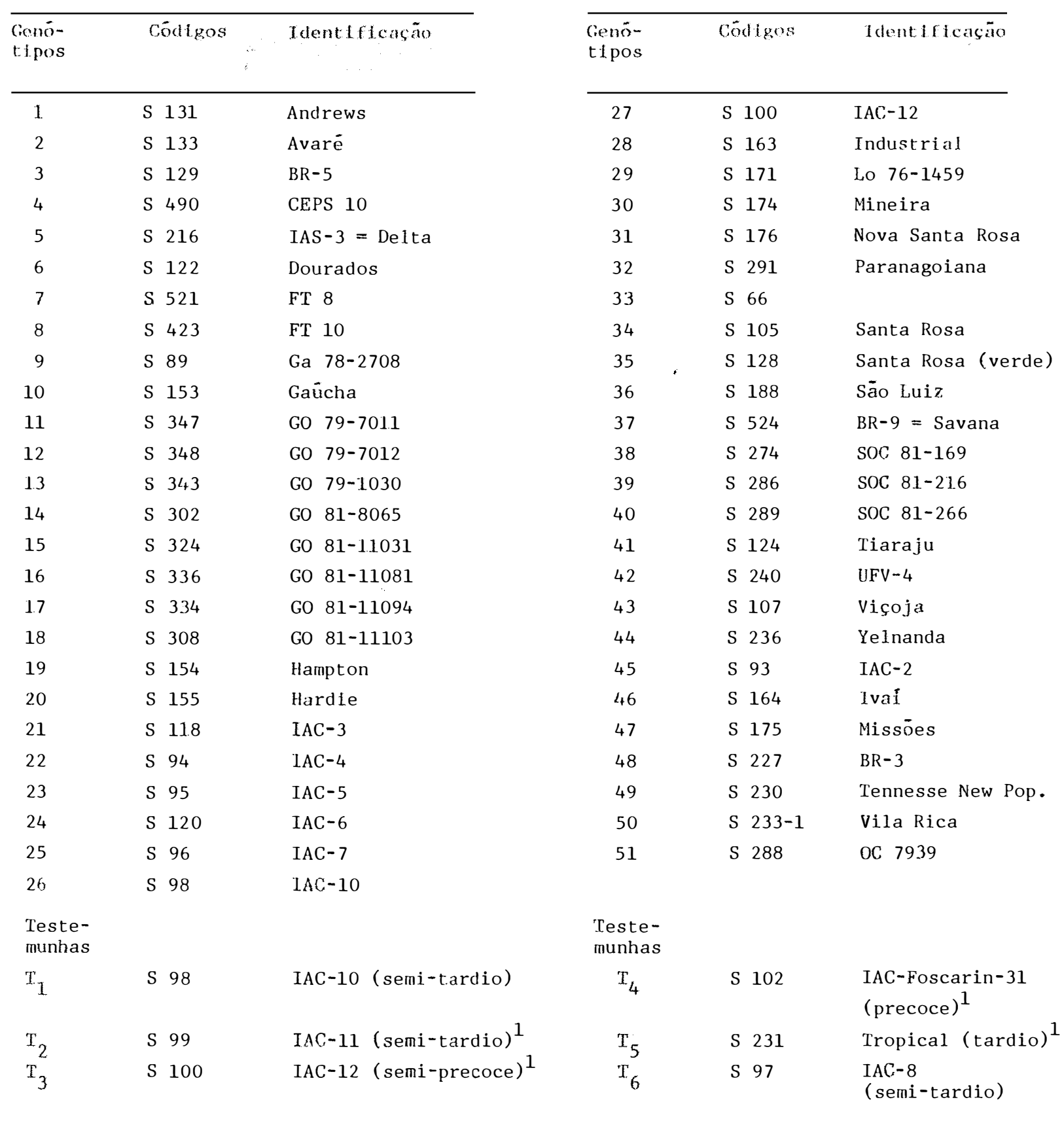

1 Testemuntras comuns. 
TABELA 4. Relação dos genótipos tardios e testemunhas com as respectivas identificações.

Genótipos

Código

Identificação

\begin{tabular}{|c|c|c|}
\hline 1 & S 397 & BR-11 (Carajās) \\
\hline 2 & S $104-1$ & Cristalina-1 \\
\hline 3 & S 143 & Doko \\
\hline 4 & S 350 & EMGOPA-301 \\
\hline 5 & S 345 & GO 79-1039 \\
\hline 6 & S 177 & Numbaira \\
\hline 7 & S 179 & Paranagoiana \\
\hline 8 & S 201 & $P I-240-664$ \\
\hline 9 & S $402-1$ & - Timbira 1 \\
\hline 10 & S $402-2$ & Timbira 2 \\
\hline 11 & S 83 & TN $82-264$ \\
\hline 12 & S 231 & Tropical \\
\hline 13 & S 242 & UFV-Araguaia \\
\hline 14 & S 237 & UFV-1 \\
\hline 15 & S 239 & $U F V-3$ \\
\hline 16 & S 241 & $U F V-5$ \\
\hline 17 & S $104-2$ & Cristalina-2 \\
\hline 18 & S 213 & IAC -9 \\
\hline 19 & S 238 & UFV-2 \\
\hline 20 & S 346 & GO $79-1084$ \\
\hline 21 & S 396 & BR-10 (Teresina) \\
\hline 22 & S 403 & BR $79-63$ \\
\hline
\end{tabular}

Testemunhas

\begin{tabular}{|c|c|c|}
\hline $\mathrm{T}_{1}$ & S 213 & IAC-9 (tardio) \\
\hline $\mathrm{T}_{2}$ & S 98 & $\begin{array}{l}\text { IAC-10 (semi- } \\
\text {-tardio) }\end{array}$ \\
\hline $\mathrm{T}_{3}$ & S 100 & $\begin{array}{l}\text { IAC-12 (semi- } \\
\text {-precoce })^{1}\end{array}$ \\
\hline $\mathrm{T}_{4}$ & S 102 & $\begin{array}{l}\text { IAC-Foscarin-31 } \\
\text { (precoce) }^{1}\end{array}$ \\
\hline $\mathrm{T}$ & S 231 & Tropical $^{(t a r d i o)^{1}}$ \\
\hline $\mathrm{T}_{6}$ & S 237 & UFV-1 (tardio) \\
\hline
\end{tabular}

1 Testemunhas comuns 


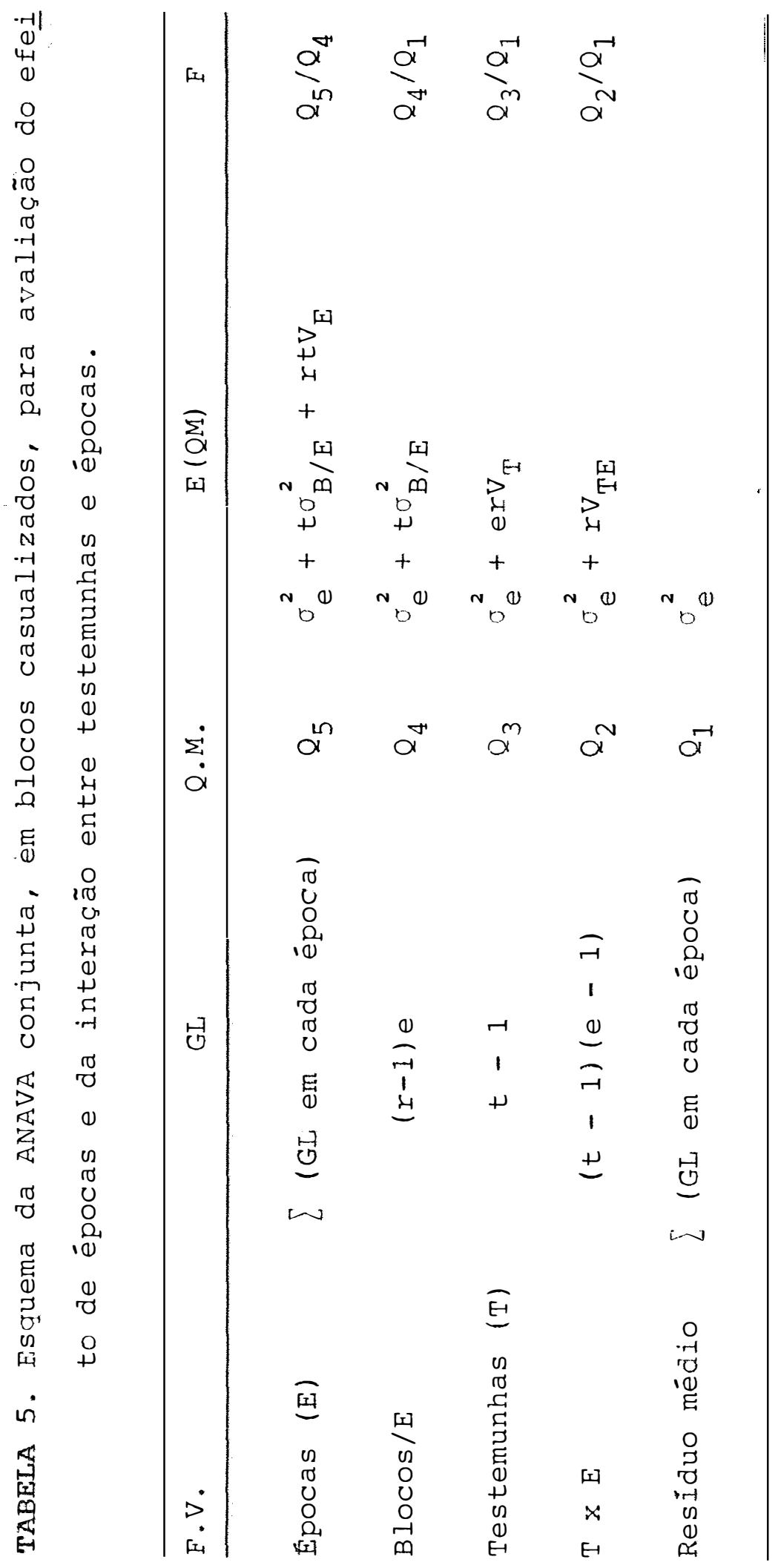


.167.

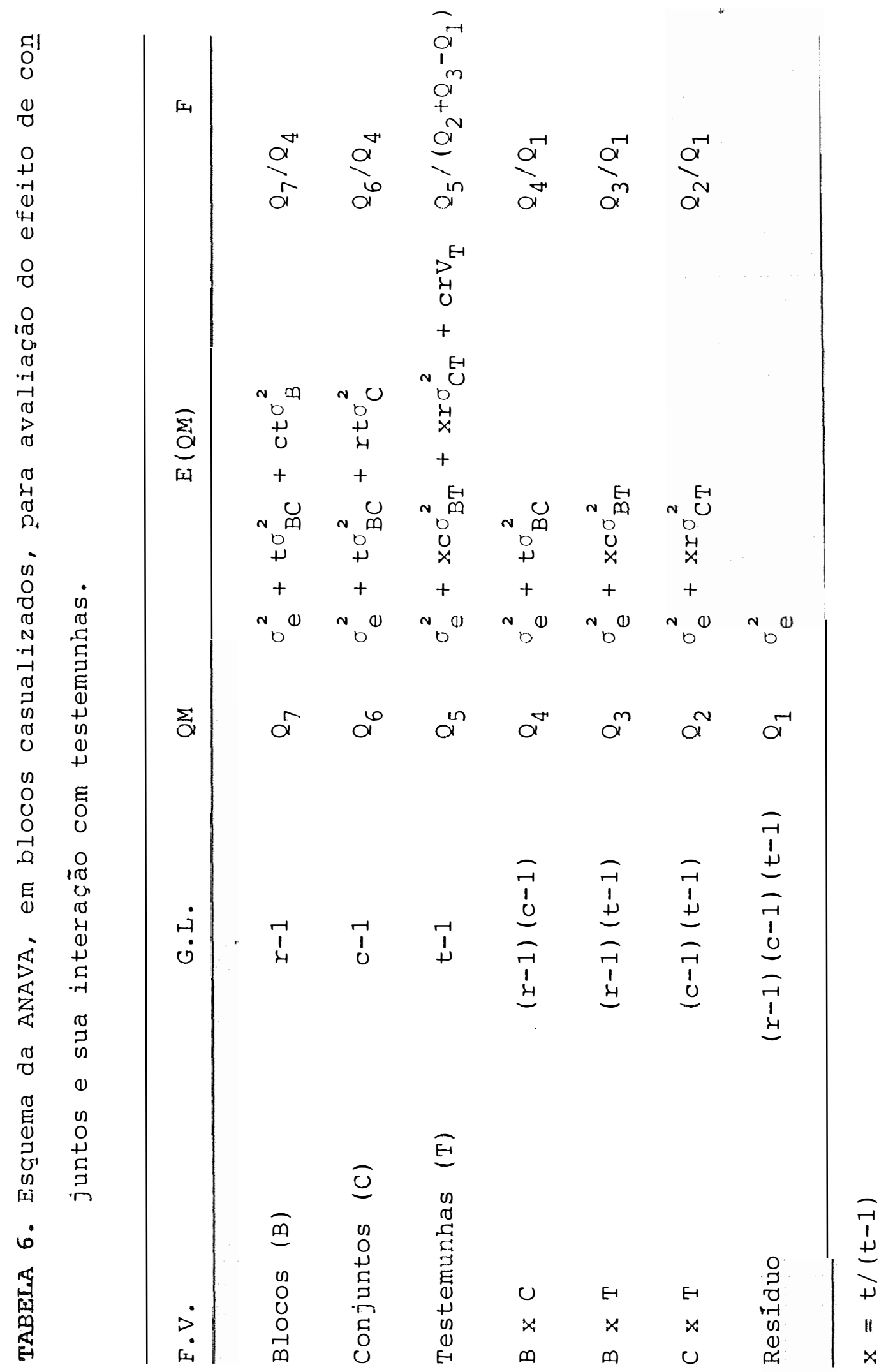


TABELA 7. Esquema da ANAVA individual, em blocos casualizados.

F. V.

G.L.

Q.M.

E (QM)

Blocos

$r-1$

Genōtipos

$9-1$

$\mathrm{Q}_{2}$

$\sigma_{e}^{2}+r V_{G}$

Resíduo

$$
(r-1)(g-1)
$$

$\mathrm{Q}_{1}$

$\sigma^{2}$ 
109.

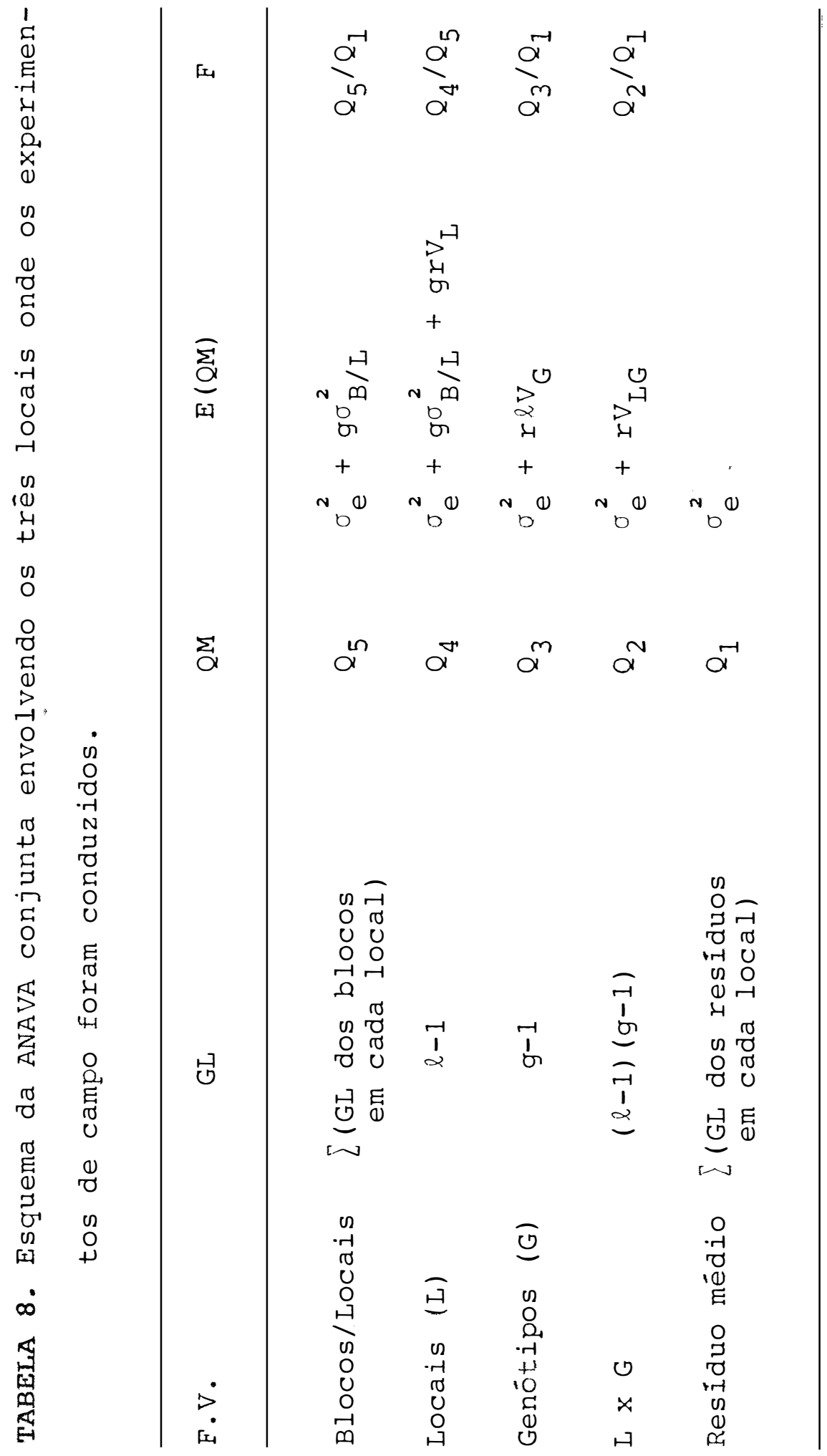


.110.
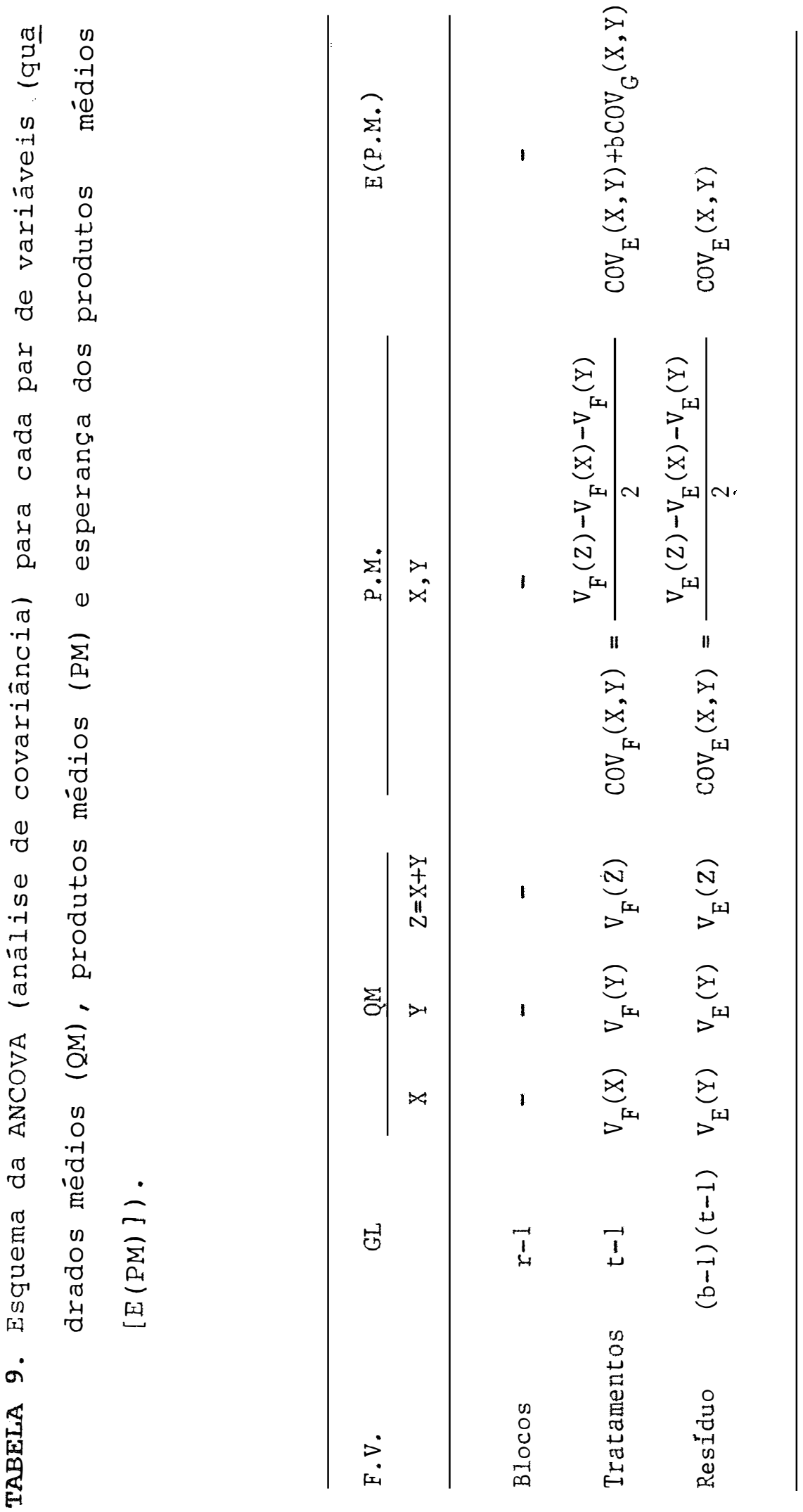
.111.

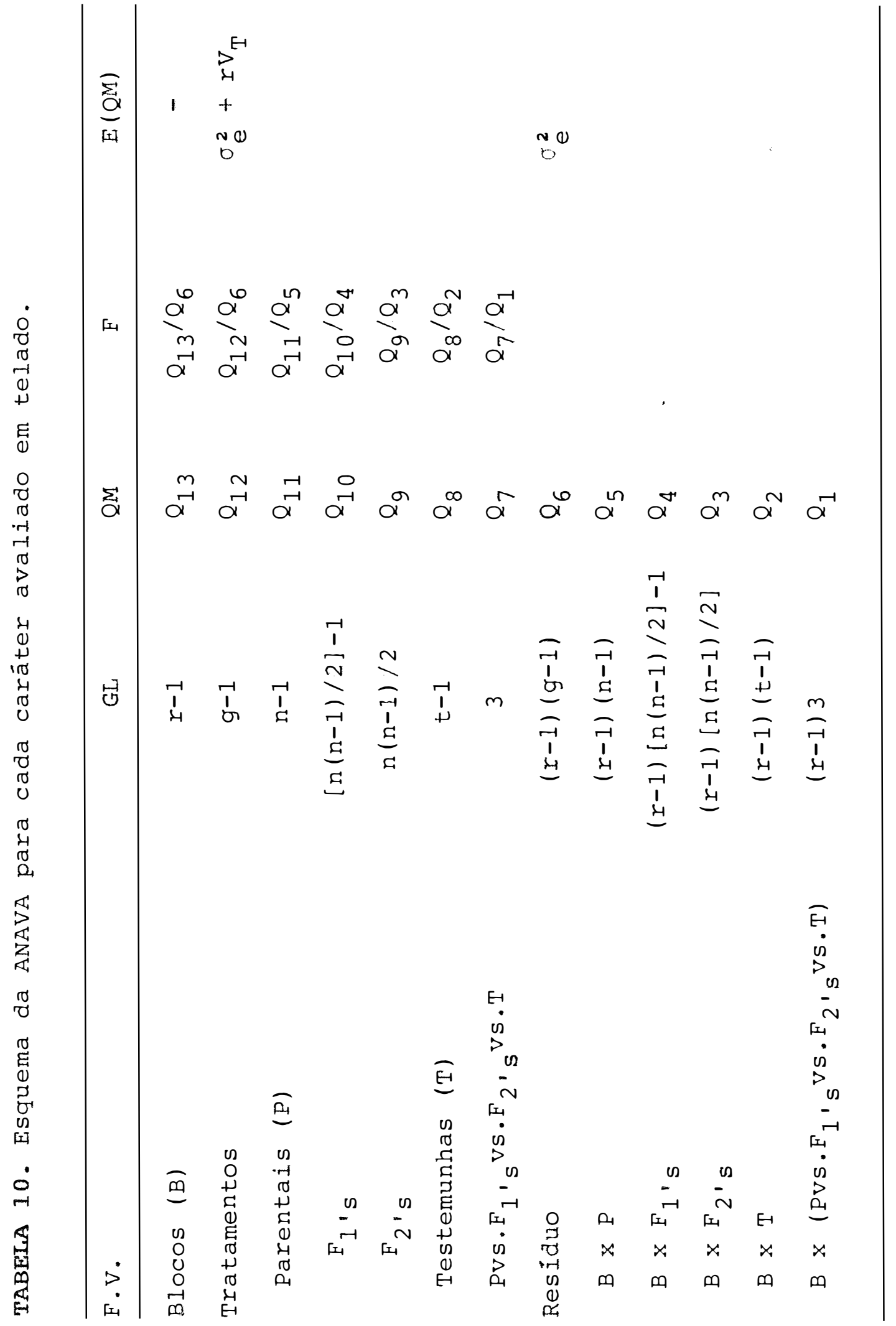


.112.

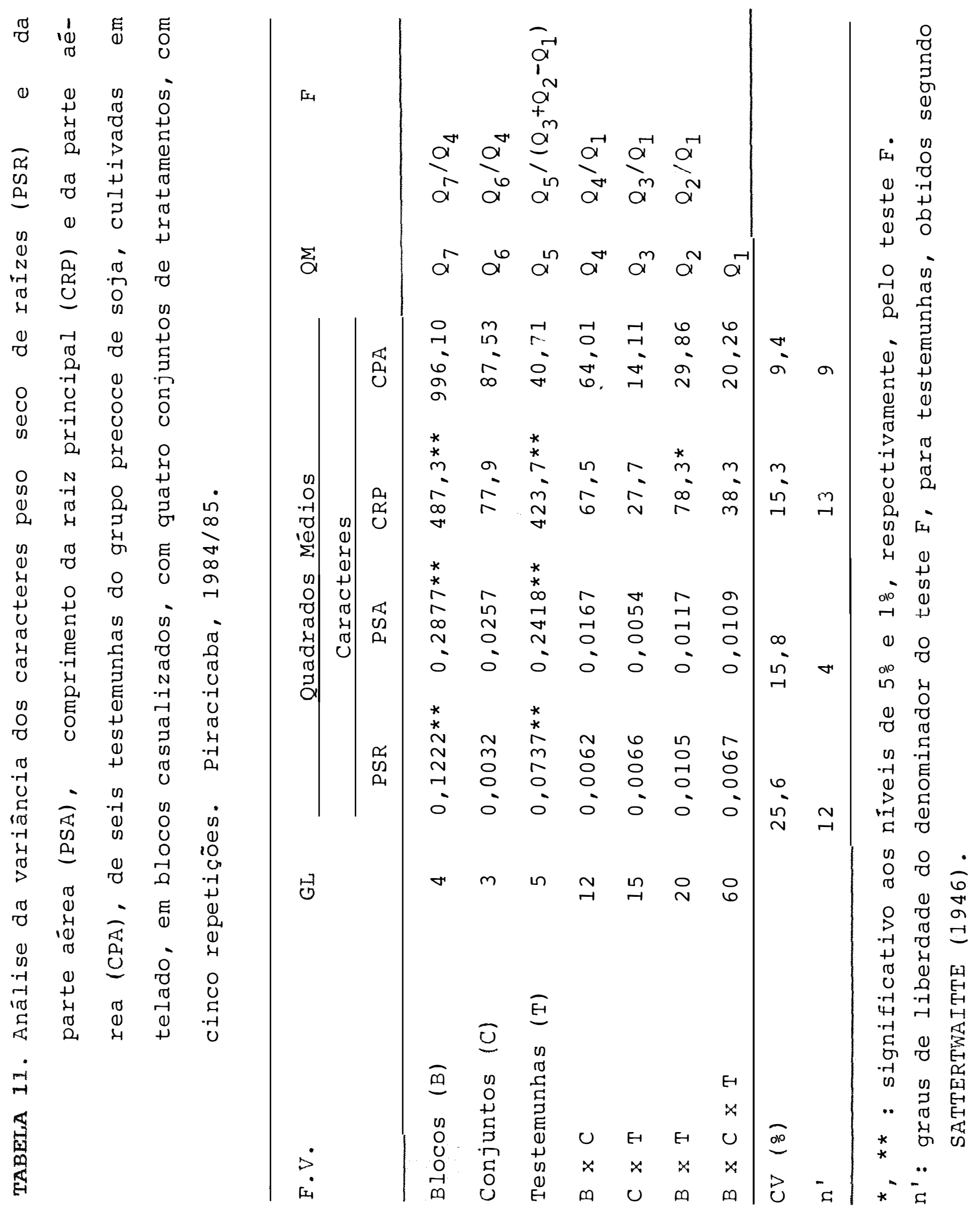


TABEla 12. Análise da variância, coeficiente de variação experimental (CV) e coeficiente de variação genotipica $\left(\mathrm{CV}_{\mathrm{G}}\right)$, para os caracteres peso seco de raizes (PSR) e da parte aérea (PSA), comprimento da raiz principal (CRP) e da parte aérea (CPA), de 80 genótipos precoces de soja, cultivados em telado. Piracicaba, $1984 / 85$.

\begin{tabular}{|c|c|c|c|c|c|}
\hline \multirow[t]{3}{*}{$F \cdot V \cdot$} & \multirow[t]{3}{*}{ GL } & \multicolumn{4}{|c|}{ Quadrados Médios } \\
\hline & & \multicolumn{4}{|c|}{ Caracteres } \\
\hline & & PSR & PSA & CRP & CPA \\
\hline Blocos & 4 & 0,23302 & 1,0427 & 546,6 & 4831,9 \\
\hline Genōtipos & 79 & $0,01403 * *$ & $0,0342 * *$ & $93,9 * *$ & 166,4 ** \\
\hline Residuo & 316 & 0,00844 & 0,0207 & 40,5 & 31,3 \\
\hline CV (응) & & 28,7 & 21,6 & 16,1 & 11,1 \\
\hline $\mathrm{CV}_{\mathrm{G}}\left(\frac{\circ}{0}\right)$ & & 10,46 & 7,79 & 8,26 & 10,33 \\
\hline
\end{tabular}

**: significativo ao nivel de 1 o de probabilidade, pelo teste $F$. 
TABEJA 13. Médias de cinco repetiçōes, para os caracteres peso seco de raízes (PSR) e da parte aérea (PSA), comprimento da raiz principal (CRP) e da parte aẻrea (CPA), de 80 genótipos precoces de soja e de seis testemunhas, cultivadas em telado. Piractcaba, 1984/85.

\begin{tabular}{|c|c|c|c|c|c|c|c|c|c|}
\hline \multirow[t]{2}{*}{ Genótipos } & \multicolumn{4}{|c|}{ Caracteres } & \multirow[t]{2}{*}{ Genötipos } & \multicolumn{4}{|c|}{ Caracteres } \\
\hline & $\mathrm{ISR}^{\prime}$ & $\operatorname{lish}^{3}$ & $\mathrm{CRP}^{2}$ & $\mathrm{CPA}^{2}$ & & $\operatorname{PSE} E^{2}$ & $\operatorname{sis} \Lambda^{2}$ & $\mathrm{CRP}^{2}$ & $\mathrm{CH}^{2}$ \\
\hline $\begin{array}{l}\text { 01. Bedford } \\
\text { 02. Bragg } \\
\text { 03. BR-2 } \\
\text { 04. BR-6 } \\
\text { 05. Campos Gerais } \\
\text { 06. Coker } 136 \\
\text { 07. Coker } 156 \\
\text { 08. Essex } \\
\text { 09. Forrest } \\
\text { 10. FT } 4 \\
\text { 11. FT } 80-86 \\
\text { 12. FT } 81-1295 \\
\text { 13. FT } 81-1797 \\
\text { 14. FT } 81-1799 \\
\text { 15. FT } 81-1802 \\
\text { 16. FT } 81-1804 \\
\text { 17. FT } 81-1805 \\
\text { 18. FT } 81-1810 \\
\text { 19. FT } 81-1815 \\
\text { 20. FT } 81-1821 \\
\text { 21. FT } 81-1823 \\
\text { 22. FT } 81-1835 \\
\text { 23. FT } 81-1848 \\
\text { 24. FT } 81-1859 \\
\text { 25. FT } 81-1864 \\
\text { 26. FT } 81-1865 \\
\text { 27. FT } 81-1869 \\
\text { 28. FT } 81-1878 \\
\text { 29. FT } 81-2044 \\
\text { 30. FT } 81-2047 \\
\text { 31. FT } 81-2050 \\
\text { 32. FT } 81-2112 \\
\text { 33. FT } 81-2115 \\
\text { 34. FT } 81-2127 \\
\text { 35. FT } 81-2132 \\
\text { 36. FT } 81-2133 \\
\text { 37. FT } 81-2134 \\
\text { 38. FT } 81-2142 \\
\text { 39. FT } 81-2148 \\
\text { 40. FT } 81-2153 \\
\text { Fis }\end{array}$ & $\begin{array}{l}0,18 \\
0,19 \\
0,33 \\
0,19 \\
0,31 \\
0,34 \\
0,36 \\
0,32 \\
0,17 \\
0,28 \\
0,27 \\
0,34 \\
0,29 \\
0,37 \\
0,32 \\
0,30 \\
0,28 \\
0,37 \\
0,34 \\
0,32 \\
0,37 \\
0,43 \\
0,39 \\
0,26 \\
0,30 \\
0,33 \\
0,25 \\
0,40 \\
0,34 \\
0,33 \\
0,31 \\
0,41 \\
0,38 \\
0,32 \\
0,36 \\
0,29 \\
0,34 \\
0,27 \\
0,32 \\
0,38\end{array}$ & $\begin{array}{l}0,54 \\
0,44 \\
0,66 \\
0,53 \\
0,75 \\
0,71 \\
0,78 \\
0,67 \\
0,44 \\
0,59 \\
0,75 \\
0,63 \\
0,72 \\
0,75 \\
0,71 \\
0,60 \\
0,57 \\
0,64 \\
0,65 \\
0,67 \\
0,89 \\
0,79 \\
0,69 \\
0,50 \\
0,71 \\
0,68 \\
0,53 \\
0,75 \\
0,77 \\
0,71 \\
0,76 \\
0,72 \\
0,66 \\
0,61 \\
0,64 \\
0,71 \\
0,64 \\
0,55 \\
0,72 \\
0,75\end{array}$ & $\begin{array}{l}25,9 \\
21,2 \\
39,5 \\
29,4 \\
36,6 \\
43,3 \\
39,3 \\
35,5 \\
33,7 \\
39,1 \\
41,8 \\
41,9 \\
37,6 \\
45,2 \\
44,2 \\
38,9 \\
34,8 \\
36,9 \\
38,9 \\
40,9 \\
40,6 \\
45,5 \\
41,9 \\
37,5 \\
36,7 \\
44,3 \\
37,1 \\
34,9 \\
45,0 \\
35,3 \\
40,0 \\
41,0 \\
41,9 \\
38,4 \\
41,3 \\
41,9 \\
40,4 \\
41,6 \\
42,6 \\
41,7\end{array}$ & $\begin{array}{l}55,8 \\
36,9 \\
47,7 \\
41,4 \\
50,5 \\
53,8 \\
46,1 \\
49,2 \\
46,5 \\
49,4 \\
51,4 \\
47,8 \\
57,3 \\
49,3 \\
49,9 \\
54,4 \\
41,0 \\
41,0 \\
48,0 \\
45,7 \\
54,4 \\
49,7 \\
40,7 \\
44,5 \\
48,8 \\
49,8 \\
48,5 \\
47,1 \\
51,8 \\
59,3 \\
57,1 \\
49,6 \\
48,1 \\
53,9 \\
46,3 \\
59,2 \\
50,2 \\
46,1 \\
53,1 \\
60,7\end{array}$ & 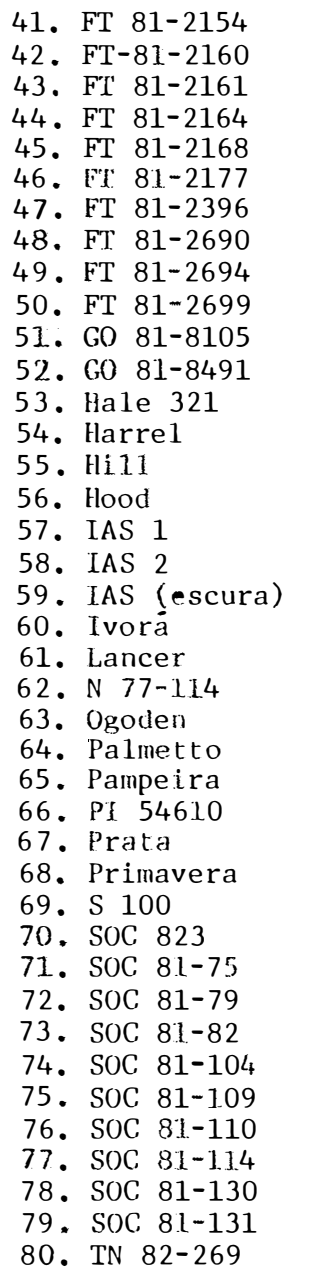 & $\begin{array}{l}0,32 \\
0,26 \\
0,29 \\
0,29 \\
0,33 \\
0,30 \\
0,29 \\
0,33 \\
0,28 \\
0,28 \\
0,37 \\
0,25 \\
0,33 \\
0,34 \\
0,33 \\
0,33 \\
0,32 \\
0,41 \\
0,41 \\
0,34 \\
0,34 \\
0,34 \\
0,30 \\
0,43 \\
0,34 \\
0,35 \\
0,34 \\
0,34 \\
0,29 \\
0,35 \\
0,31 \\
0,29 \\
0,33 \\
0,38 \\
0,31 \\
0,36 \\
0,29 \\
0,27 \\
0,30 \\
0,27 \\
0,37 \\
0,35 \\
0,31 \\
0,37 \\
0,31 \\
0,26 \\
0,30 \\
0,30\end{array}$ & $\begin{array}{l}0,71 \\
0,62 \\
0,72 \\
0,66 \\
0,69 \\
0,72 \\
0,59 \\
0,64 \\
0,71 \\
0,58 \\
0,70 \\
0,64 \\
0,68 \\
0,64 \\
0,82 \\
0,69 \\
0,64 \\
0,60 \\
0,69 \\
0,68 \\
0,75 \\
0,63 \\
0,71 \\
0,60 \\
0,92 \\
0,62 \\
0,63 \\
0,66 \\
0,65 \\
0,66 \\
0,71 \\
0,71 \\
0,66 \\
0,55 \\
0,68 \\
0,61 \\
0,57 \\
0,68 \\
0,58 \\
0,68\end{array}$ & $\begin{array}{l}42,3 \\
37,3 \\
40,7 \\
43,0 \\
49,7 \\
34,9 \\
42,0 \\
42,0 \\
37,5 \\
38,1 \\
40,7 \\
43,3 \\
43,6 \\
43,4 \\
36,4 \\
34,5 \\
40,1 \\
45,1 \\
37,9 \\
45,6 \\
43,9 \\
43,9 \\
43,9 \\
43,2 \\
40,3 \\
37,4 \\
33,9 \\
36,1 \\
36,1 \\
36,5 \\
36,5 \\
43,9 \\
40,3 \\
45,3 \\
43,3 \\
43,3 \\
39 \\
42,0 \\
32,3 \\
43,0 \\
33,0 \\
42,4 \\
40,4 \\
35,3 \\
41,2 \\
4\end{array}$ & $\begin{array}{l}59,6 \\
55,3 \\
51,3 \\
50,4 \\
49,9 \\
58,8 \\
49,3 \\
65,7 \\
54,5 \\
58,6 \\
50,1 \\
53,8 \\
49,0 \\
49,5 \\
52,0 \\
49,6 \\
48,9 \\
42,2 \\
49,4 \\
45,6 \\
52,3 \\
39,5 \\
52,3 \\
53,5 \\
42,0 \\
68,9 \\
40,6 \\
44,6 \\
49,9 \\
56,6 \\
49,7 \\
48,6 \\
54,7 \\
45,0 \\
52,2 \\
56,3 \\
53,5 \\
47,6 \\
44,0 \\
48,9\end{array}$ \\
\hline Média & & & & & & $\begin{array}{l}0,32^{ \pm} \\
0,01\end{array}$ & $\begin{array}{l}0,66^{ \pm} \\
0,16\end{array}$ & $\begin{array}{c}39,6^{ \pm} \\
0,5\end{array}$ & $\begin{array}{c}50,3^{ \pm} \\
0,6\end{array}$ \\
\hline d.m.s. $(1 \%)$ & & & & & & 0,27 & 0,42 & 18,5 & 16,3 \\
\hline \multicolumn{10}{|l|}{ Testemunhas } \\
\hline $\mathrm{T}_{1} \cdot \operatorname{IAC} 11$ & ט, & 00 & 40,1 & 40, & $\mathrm{~T}_{4} \cdot \operatorname{las} 5$ (clar & 0,30 & 0,59 & 37,5 & 45,7 \\
\hline $\mathrm{T}_{2} \cdot$ IAC 12 & 0,37 & 0,64 & 41,2 & 47,1 & $\mathrm{~T}_{5} \cdot$ Paraná & 0,35 & 0,70 & 44,5 & 48,7 \\
\hline $\mathrm{T}_{3} \cdot$ IAC Foscarin-31 & 0,28 & 0,59 & 39,9 & 49,5 & $6^{-}$Tropical. & 0,23 & 0,56 & 33,5 & 48,8 \\
\hline Média & & & & & & 0,32 & 0,65 & 40,4 & 48,1 \\
\hline
\end{tabular}

d.m.s. = diferença mínima significativa, pelo teste de Tukey.

1 : PSR e PSA avaliados:em g/planta

2 : CRP e CPA : avaliados em cm/planta 
TABELA 14. Estimativas de coeficientes de correlações fenotipica $\left(r_{F}\right)$, ambiental $\left(r_{E}\right)$ e genotipica $\left(r_{G}\right)$, variāncia genotípica $\left(V_{G}\right)$ e coeficiente de determinação genotípica (b) dos caracteres peso seco de raízes (PSR) e dà parte aérea (PSA), comprimento da raiz principal (CRP) e da parte aērea (CPA), para 80 genótipos precoces de soja cultivados em telado. Piracicaba, $1984 / 85$.

\begin{tabular}{|c|c|c|c|c|c|}
\hline Caracteres & $r$ & PSR & PSA & CRP & $\mathrm{CPA}$ \\
\hline \multirow[t]{3}{*}{ PSR } & $\mathrm{F}$ & & 0,602 & 0,621 & 0,018 \\
\hline & $\mathrm{E}_{1}$ & & $-0,505$ & 0,306 & $-0,058$ \\
\hline & G & & 0,748 & 0,978 & 0,065 \\
\hline \multirow[t]{3}{*}{ PSA } & $F^{\prime}$ & & & 0,464 & 0,240 \\
\hline & $E_{1}$ & & & 0,245 & 0,157 \\
\hline & G & & & 0,715 & 0,312 \\
\hline \multirow[t]{3}{*}{ CRP } & $\mathrm{F}$ & & & & 0,200 \\
\hline & $E_{1}$ & & & & $-0,043$ \\
\hline & G & & & & 0,312 \\
\hline$v_{G}$ & & 0,00112 & 0,00270 & 10,68 & 27,03 \\
\hline $\mathrm{b}$ & & 0,398 & 0,394 & 0,569 & 0,812 \\
\hline
\end{tabular}




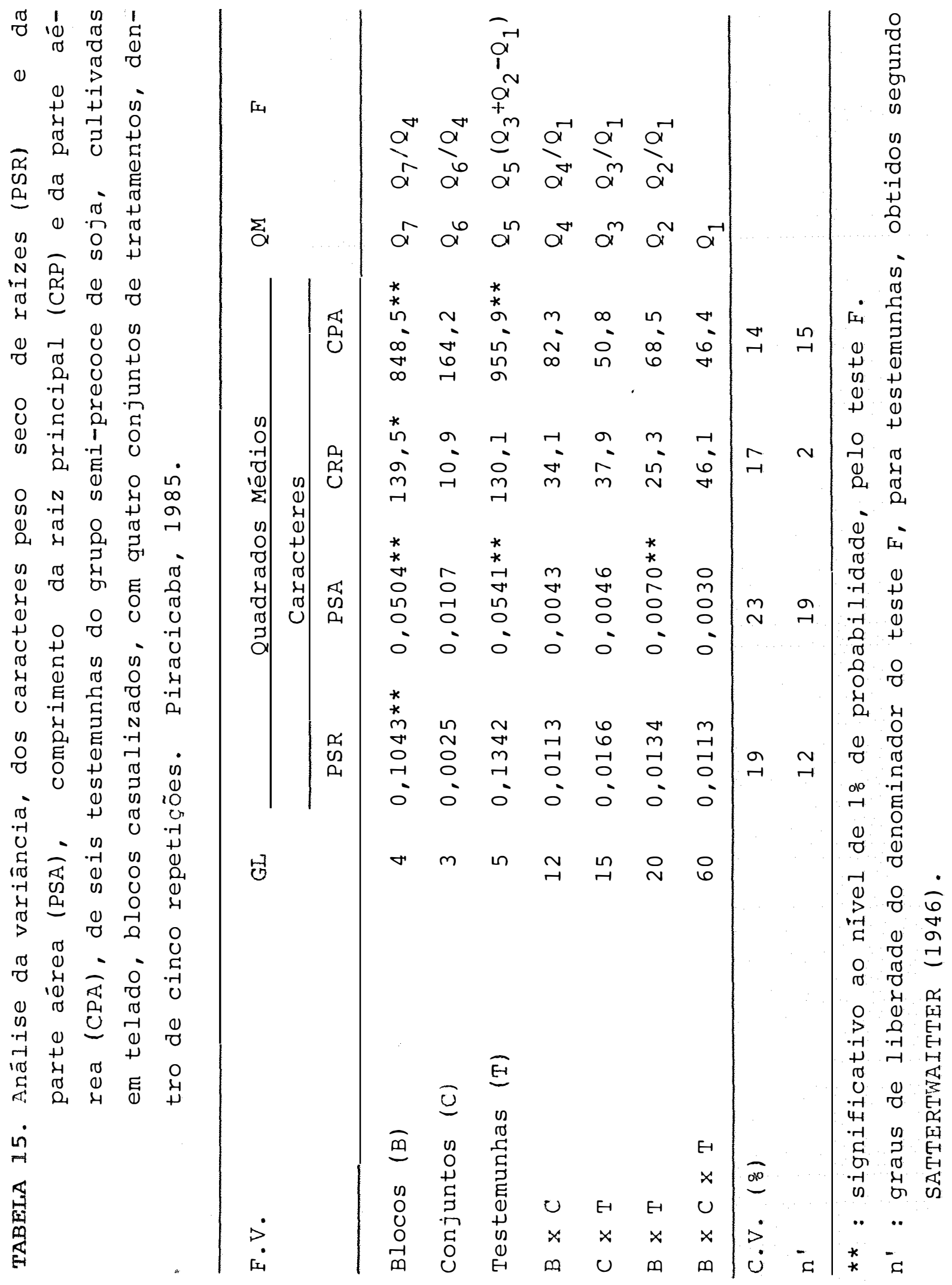


.117.

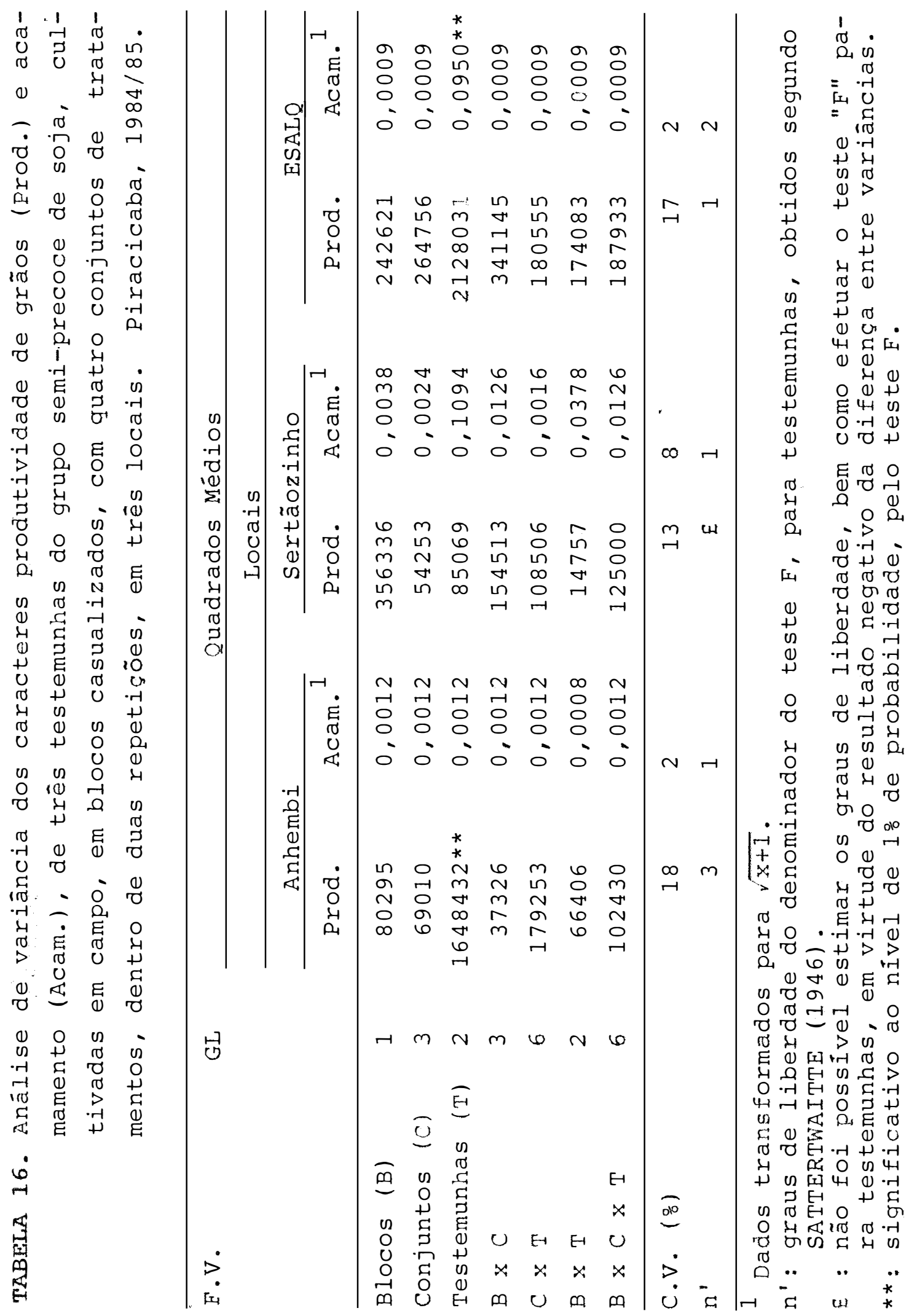


TABELA 17. Anālise de variāncia, coeficiente de variação experimental (CV) e coeficiente de variação genotípica $\left(\mathrm{CV}_{\mathrm{G}}\right)$ para os caracteres peso seco de raízes $(P S R)$ e da parte aérea (PSA), em (g/planta) ${ }^{2}$, com primento da raiz principal (CRP) e da parte aérea $(\mathrm{CPA})$, em $(\mathrm{cm} / \mathrm{planta})^{2}$, de 62 genótipos semi-precoces de soja, cultivados em telado. Piracicaba, 1985 .

\begin{tabular}{|c|c|c|c|c|c|}
\hline \multirow[t]{3}{*}{$\mathrm{F} \cdot \mathrm{V} \cdot$} & \multirow[t]{3}{*}{ GL } & \multicolumn{4}{|c|}{ Quadrados Médios } \\
\hline & & \multicolumn{4}{|c|}{ Caracteres } \\
\hline & & PSR & PSA & $\mathrm{CRP}$ & $\mathrm{CPA}$ \\
\hline Blocos & 4 & 0,1136 & 0,4088 & 169,8 & $2.547,1$ \\
\hline Genōtipos & 61 & $0,0081 * \star$ & $0,0316 * \star$ & $52,8 * \star$ & $113,5 *$ * \\
\hline Resíduo & 244 & 0,0045 & 0,0120 & 31,5 & 48,0 \\
\hline C.V. ( $\left(\frac{\circ}{8}\right)$ & & 27,04 & 19,04 & 13,8 & 14,1 \\
\hline $\mathrm{CV}_{\mathrm{G}}\left(\frac{\circ}{0}\right)$ & & 10,67 & 10,78 & 0,40 & 7,34 \\
\hline
\end{tabular}

**: significativo ao nível de 1 \& de probabilidade pelo teste $F$. 
TABEJA 18. Médias de cinco repetições para os caracteres peso seco de raízes (PSR) e da parte aérea (PSA), - comprimento da raiz principal (CRP) e da parte aérea (CPA), de 62 genötipos semi-precoces de soja, cultivados em telado. Piracicaba, 1985.

\begin{tabular}{|c|c|c|c|c|c|c|c|c|c|}
\hline \multirow{3}{*}{$\begin{array}{l}\text { Genótipos } \\
01 \text { Ax 53-55 }\end{array}$} & \multicolumn{4}{|c|}{ Caracteres } & \multirow{3}{*}{$\begin{array}{l}\text { Genótipos } \\
\text { 32. G0 } 81-11075\end{array}$} & \multicolumn{4}{|c|}{ Caracteres } \\
\hline & \multicolumn{2}{|c|}{$\begin{array}{l}\text { PSR PSA } \\
\text { g/planta }\end{array}$} & \multicolumn{2}{|c|}{$\begin{array}{l}\text { CRP CPA } \\
\mathrm{cm} / \text { plant.a }\end{array}$} & & \multicolumn{2}{|c|}{$\begin{array}{l}\text { PSR PSA } \\
\text { g/planta }\end{array}$} & \multicolumn{2}{|c|}{$\begin{array}{l}\text { CRP CPA } \\
\text { cm/planta }\end{array}$} \\
\hline & 0,23 & 0,53 & 42,0 & 44,0 & & 0,27 & 0,50 & 44,9 & 46,4 \\
\hline 02. Batavian Yellow & 0,22 & 0,63 & 39,4 & 51,0 & 33. IAC 1 & 0,24 & 0,58 & 35,9 & 48,2 \\
\hline 03. Biloxi & 0,25 & 0,52 & 42,2 & 46,2 & 34. IAC 12 & 0,23 & 0,46 & 37,9 & 46,1 \\
\hline 04. Bossier & 0,24 & 0,75 & 43,1 & 61,0 & 35. Іарӧ & 0,27 & 0,61 & 42,9 & 47,1 \\
\hline 05. BR 1 & 0,20 & 0,49 & 38,1 & 46,1 & 36. IPAGRO 20 & 0,25 & 0,46 & 39,8 & 43,6 \\
\hline 06. BR 1 (fosca) & 0,17 & 0,39 & 38,2 & 42,7 & 37. Jackson, & 0,26 & 0,66 & 36,8 & 48,6 \\
\hline 07. BR 4 & 0,26 & 0,69 & 48,5 & 56,1 & 38. Kershaw & 0,29 & 0,66 & 42,0 & 51,3 \\
\hline 08. BR 6 & 0,22 & 0,53 & 38,4 & 44,1 & 39. Kirby & 0,27 & 0,70 & 43,4 & 56,8 \\
\hline 09. BR 80-6935 & 0,22 & 0,63 & 40,5 & 57,9 & 40. La 49-10-215 & 0,27 & 0,66 & 37,8 & 44,8 \\
\hline 10. BR $80-14887$ & 0,18 & 0,55 & 36,8 & 44,8 & 4.1. OC $78-503$ & 0,27 & 0,59 & 42,4 & 52,4 \\
\hline 11. Centennial & 0,26 & 0,72 & 44,2 & 50,8 & 42. OC $79-5$ & 0,27 & 0,55 & 44,8 & 47,6 \\
\hline 12. CEPS $77-16$ & 0,24 & 0,61 & 41,2 & 57,9 & 43. OC $79-7$ & 0,23 & 0,53 & 41,1 & 49,2 \\
\hline 13. CNS & 0,28 & 0,58 & 43,1 & 45,1 & 44. OC 79-20 & 0,31 & 0,54 & 39,7 & 50,3 \\
\hline 14. Cobb & 0,19 & 0,54 & 40,4 & 51,3 & 45. OC $79-84$ & 0,26 & 0,56 & 42,0 & 42,1 \\
\hline 15. Davis & 0,24 & 0,47 & 39,2 & 46,2 & 46. OC $79-136$ & 0,23 & 0,56 & 42,6 & 51,3 \\
\hline 16. Década & 0,22 & 0,61 & 44,2 & 50,7 & 47. OC $79-230$ & 0,24 & 0,45 & 37,6 & 44,6 \\
\hline 17. Dourados & 0,25 & 0,66 & 39,2 & 56,7 & 48. OC $79-493$ & 0,27 & 0,56 & 38,1 & 43,0 \\
\hline 18. Foster & 0,19 & 0,48 & 40,6 & 50,6 & 49. OC 79-504 & 0,21 & 0,52 & 37,7 & 51,0 \\
\hline 19. FT 1 & 0,37 & 0,66 & 39,5 & $43, \bullet$ & 50. Pérola & 0,35 & 0,64 & 41,9 & 47,7 \\
\hline 20. FT 2 & 0,30 & 0,67 & 47,3 & 50,6 & 51. PI 322-694 & 0,26 & 0,66 & 42,4 & 53,0 \\
\hline 21. FT 5 & 0,22 & 0,60 & 36,3 & 59,6 & 52. Pichett 71- & & & & \\
\hline 22. FT 6 & 0,28 & 0,65 & 42,0 & 52,3 & 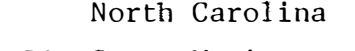 & 0,27 & 0,60 & 36,2 & 49,3 \\
\hline 23. FT 7 & 0,33 & 0,66 & 41,2 & 46,7 & 53. Santa Maria & 0,26 & 0,52 & 42,5 & 53,9 \\
\hline 24. FT 9 & 0,23 & 0,59 & 38,2 & 47,0 & 54. SOC $81-76$ & 0,29 & 0,74 & 43,4 & 51,4 \\
\hline 25. FT $79-3408$ & 0,29 & 0,54 & $4+3,8$ & 45,9 & 55. SOC $81-105$ & 0,24 & 0,54 & 40,2 & 44,6 \\
\hline 26. FT $79-3415$ & 0,25 & 0,52 & 36,7 & 45,9 & 56. SOC $81-119$ & 0,17 & 0,46 & 32,5 & 44,1 \\
\hline 27. FT $81-2136$ & 0,21 & 0,53 & 37,6 & 58,0 & 57. SOC $81-124$ & 0,18 & 0,53 & 38,1 & 52,4 \\
\hline 28. FT $81-2163$ & 0,25 & 0,62 & 45,4 & 53,9 & 58. SOC $81-145$ & 0,22 & 0,59 & 37,1 & 48,3 \\
\hline 29. FT $81-2706$ & 0,30 & 0,71 & 46,2 & 59,3 & 59. SOC $81-228$ & 0,26 & 0,50 & 40,1 & 49,0 \\
\hline 30. GO 81-8102 & 0,23 & 0,58 & 45,3 & 46,3 & 60. Sulina & 0,21 & 0,56 & 43,7 & 50,1 \\
\hline 31. CO $81-8106$ & 0,28 & 0,55 & 48,2 & 47,8 & $\begin{array}{l}\text { 61. Tiaraju } \\
\text { 62. TN } 82-273\end{array}$ & $\begin{array}{l}0,23 \\
0,25\end{array}$ & $\begin{array}{l}0,44 \\
0,50\end{array}$ & $\begin{array}{l}39,3 \\
40,1\end{array}$ & $\begin{array}{l}44,0 \\
49,0\end{array}$ \\
\hline Média & & & & & & $\begin{array}{l}0,25^{ \pm} \\
0,01\end{array}$ & $\begin{array}{l}0,57^{ \pm} \\
0,01\end{array}$ & $\begin{array}{c}40,8^{ \pm} \\
0,7\end{array}$ & $\begin{array}{c}49,3 \pm \\
0,9\end{array}$ \\
\hline d.m.s. $(\%)$ & & & & & & 0,19 & 0,31 & 15,9 & 19,6 \\
\hline \multicolumn{10}{|l|}{ Testemunhas } \\
\hline $\mathrm{T}_{1}$. Bossier & 0,17 & 0,51 & 36,0 & 49,8 & $\mathrm{~T}_{4} \cdot \mathrm{IAC} 12$ & 0,22 & 0,62 & 41,5 & 62,1 \\
\hline $\mathrm{T}_{2} \cdot$ Davis & 0,32 & 0,70 & 42,8 & 49,8 & $\mathrm{~T}_{5} \cdot$ IAC Foscarin-31 & 0,27 & 0,55 & 40,6 & 45,5 \\
\hline $\mathrm{T}_{3} \cdot$ IAC 11 & 0,24 & 0,55 & 42,8 & 47,6 & $\mathrm{~T}_{6} \cdot$ Tropical & 0,24 & 0,47 & 41,8 & 41,7 \\
\hline Média & & & & & & 0,24 & 0,57 & 40,9 & 49,4 \\
\hline
\end{tabular}

d.m.s. : diferença minima significativa, pelo teste de lukey. 


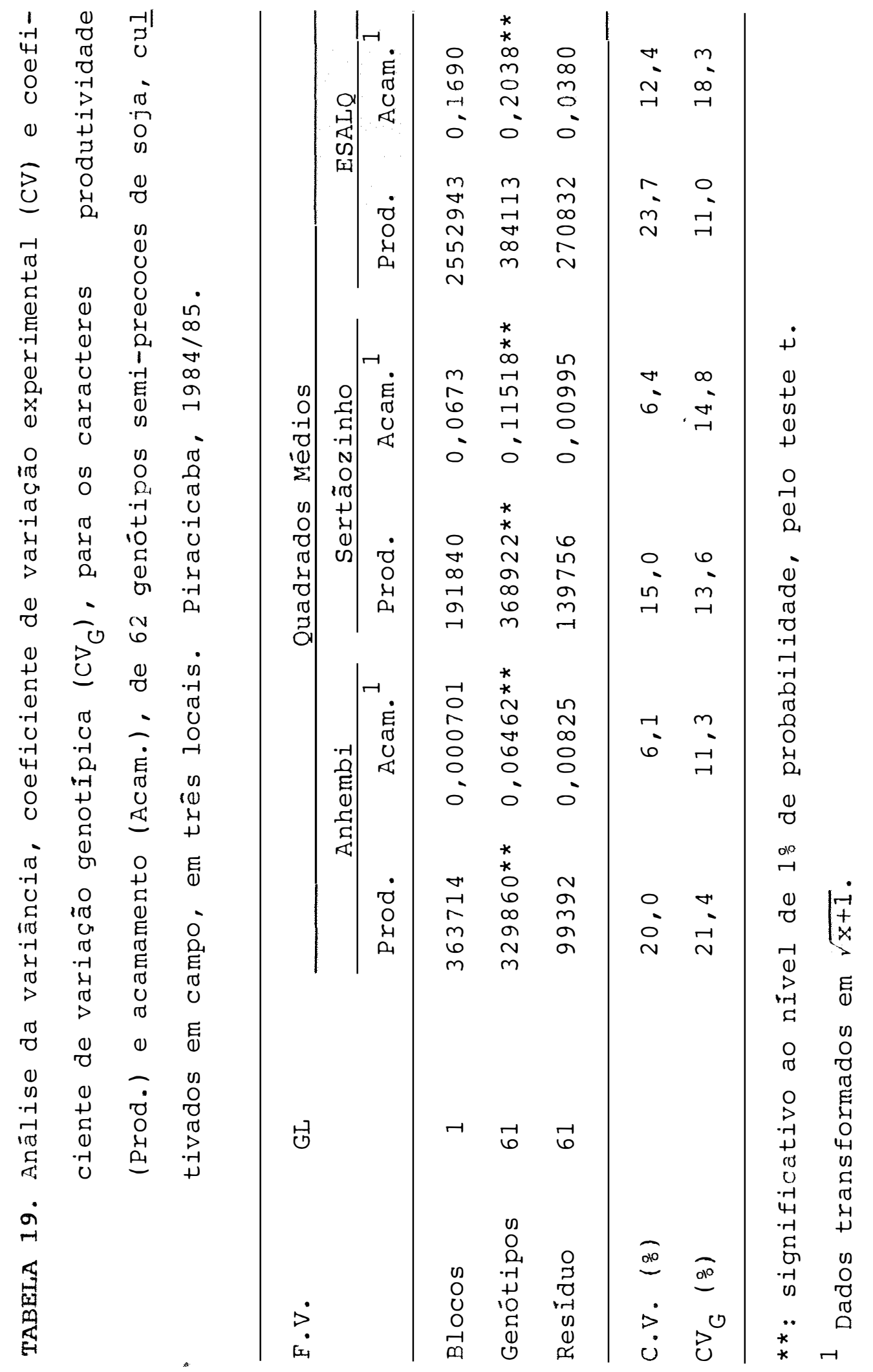


TABELA 20. Médias de duas repetiçōes, para os caracteres produtividade de gräos (Prod.) e acamamento (Acam.) de 62 genótipos semi-precoces de soja, cultivados em campo, em trēs locais. Piracicaba.

\begin{tabular}{|c|c|c|c|c|c|c|}
\hline \multirow[t]{3}{*}{ Genótipos } & \multicolumn{6}{|c|}{ Locais } \\
\hline & \multicolumn{2}{|c|}{ Antrembl } & \multicolumn{2}{|c|}{ sertioginho } & \multicolumn{2}{|c|}{ ESALO } \\
\hline & $\begin{array}{l}\text { Prod. } \\
\text { kg/ha }\end{array}$ & $\begin{array}{r}\text { Acam. } \\
(1 \text { a } 5) \\
\end{array}$ & $\begin{array}{l}\text { Prod. } \\
\mathrm{kg} / \mathrm{ha}\end{array}$ & $\begin{array}{c}\text { Acam. } \\
(1 \text { a } 5)\end{array}$ & $\begin{array}{l}\text { Prod. } \\
\mathrm{kg} / \mathrm{ha}\end{array}$ & $\begin{array}{r}\text { Acam. } \\
(1 \mathrm{a} 5) \\
\end{array}$ \\
\hline 01. Ax 53-55 & 1208,3 & 1,41 & 2541,7 & 1,41 & 2291,7 & 1,41 \\
\hline 02. Batavian Yellow & 1250,0 & 1,98 & 2375,0 & 2,18 & 2395,8 & 1,41 \\
\hline 03. Biloxi & $17.18,7$ & 2,00 & 1895,8 & 2,29 & 2312,5 & 2,31 \\
\hline 04. Bossier & $1.125,0$ & 1,46 & 2729,2 & 1,41 & 2562,5 & 1,46 \\
\hline 05. BR 1 & 2083,3 & 1,41 & 2604,2 & 1,41 & 2229,2 & 1,41 \\
\hline 06. BR 1 (fosco) & 1833,3 & 1,49 & 2333,3 & 1.,49 & 2041,7 & 1,41 \\
\hline 07. BR 4 & 1458,3 & 1,41 & 2435,5 & 1,41 & 1562,5 & 1,41 \\
\hline 08. BR 6 & 1395,8 & 1,41 & 2750,0 & 1,41 & 2333,3 & 1,41 \\
\hline 09. BR 80-6935 & 1833,3 & 1,41 & 2458,3 & 1,58 & 2125,0 & 1,77 \\
\hline 10. BR $80-14887$ & 1666,7 & 1,44 & 2770,8 & 1,58 & 1958,3 & 1,58 \\
\hline 11. Centennial & 791,7 & 1,49 & 1500,0 & 1,41 & 1791,7 & 1,49 \\
\hline 12. CEPS 77-16 & 1479,2 & 1,41 & 2729,2 & 1,41 & 2020,8 & 1,41 \\
\hline 13. CNS & 1208,3 & 1,41 & 2687,5 & 1,57 & 1416,7 & 1,41 \\
\hline 14. Cobb & 2312,5 & 1,41 & 2666,7 & 1,41 & 2729,2 & 1,41 \\
\hline 15. Davis & 1666,7 & 1,41 & 2687,5 & 1,41 & 2770,8 & 1,41 \\
\hline 16. Década & 937,5 & 1,41 & 1770,8 & 1,41 & 2187,5 & 1,93 \\
\hline 17. Dourados & 2000,0 & 1,41 & 2437,5 & 1,65 & 2687,5 & 1,84 \\
\hline 18. Foster & 1395,8 & 1,41 & 2520,8 & 1,41 & 2687,5 & 1,41 \\
\hline 19. FT 1 & 1791,7 & 1,41 & 2583,3 & 1,41 & 1895,8 & 1,41 \\
\hline 20. FT 2 & 1708,3 & 1,41 & 2979,2 & 1,41 & 3041,7 & 1,49 \\
\hline 21. FT 5 & 1104,2 & 1,41 & 2770,8 & 1,41 & 2291,7 & 1,41 \\
\hline 22. FT 6 & 1666,7 & 1,41 & 2645,8 & 1,49 & 1541,7 & 1,49 \\
\hline 23. FT 7 & 2020,8 & 1,41 & 2562,5 & 1,41 & 1875,0 & 1,41 \\
\hline 24. FT 9 & 2062,5 & 1,41 & 2416,7 & 1,41 & 2354,2 & 1,41 \\
\hline 25. FT $79-3408$ & 1895,8 & 1,41 & 2798,3 & 1,41 & 3020,8 & 1,41 \\
\hline 26. FT $79-3415$ & 1395,8 & 1,41 & 2958,3 & 1,41 & 2250,0 & 1,41 \\
\hline 27. FT $81-2136$ & 1437,5 & 1,41 & 2375,0 & 1,57 & 2166,7 & 2,09 \\
\hline 28. FT $81-2163$ & 1437,5 & 1,41 & 2520,8 & 1,41 & 1750,0 & 1,41 \\
\hline 29. FT $81-2706$ & $214.5,8$ & 1,41 & 2291,7 & 1,41 & 2125,0 & 1,41 \\
\hline 30. GO 81-8102 & 1833,3 & 1,98 & 2375,9 & 2,06 & 2541,7 & 2,08 \\
\hline 31. (C) $81-8106$ & 1437,5 & 2,12 & 2375,0 & $?, 00$ & 2229,2 & 2,12 \\
\hline $32.6081-11075$ & 1979,2 & 1,96 & 2020,8 & 2,00 & 1958,3 & 2,24 \\
\hline 33. IAC 1 & 2291,7 & 1,57 & 2166,7 & 2,12 & 2450,0 & 1,92 \\
\hline 34. IAC 12 & 1854,2 & 1,41 & 2687,5 & 1,49 & 2520,8 & 1,41 \\
\hline 35. 1apó & 1958,3 & 1,41 & 2500,0 & 1,41 & 1604,2 & 1,41 \\
\hline 36. IPAGRO 20 & 1687,5 & 1,41 & 2666,7 & 1,41 & 1833,3 & 1,41 \\
\hline 37. Jackson & 1125,0 & 1,41 & 2291,7 & 1,41 & 3229,2 & 1,41 \\
\hline 38. Kershaw & 1645,8 & 1,41 & 2520,8 & 1,41 & 2083,3 & 1,41 \\
\hline
\end{tabular}


TABELA 20. continuaçāo

\begin{tabular}{|c|c|c|c|c|c|c|}
\hline \multirow[t]{3}{*}{ Genótipos } & \multicolumn{6}{|c|}{ Locais } \\
\hline & \multicolumn{2}{|c|}{ Anhembi } & \multicolumn{2}{|c|}{ Sertäozinho } & \multicolumn{2}{|c|}{ ESALQ } \\
\hline & $\begin{array}{l}\text { Prod. } \\
\mathrm{kg} / \mathrm{lia}\end{array}$ & 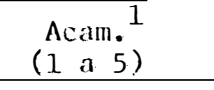 & $\begin{array}{l}\text { Prod. } \\
\mathrm{kg} / \mathrm{hal}\end{array}$ & $\begin{array}{c}\text { Acam. } \\
\left(\begin{array}{lll}1 & a & 5\end{array}\right)\end{array}$ & $\begin{array}{l}\text { Prod. } \\
\mathrm{kg} / \mathrm{ha}\end{array}$ & $\begin{array}{r}\text { Acam. } \\
(1 \mathrm{a} \cdot 5) \\
\end{array}$ \\
\hline $39 . k 1$ rby & $14,17,5$ & $1,4,1$ & 2645,8 & 1,41 & 2791,7 & $1,4,1$ \\
\hline 40. La 49-10-215 & 1416,7 & 1,41 & 2687,5 & 1,64 & 2354,2 & 1,62 \\
\hline 41. OC $78-503$ & 1312,5 & 1,41 & 2500,0 & 1,49 & 2333,3 & 1,41 \\
\hline 42. OC $79-5$ & $1.625,0$ & 1,41 & 2916,7 & 1,49 & 2583,3 & 1,41 \\
\hline 43. OC $79-7$ & 1479,2 & 1,41 & 3187,5 & $1,4,9$ & 1583,3 & 1,49 \\
\hline 44. OC $79-20$ & 1666,7 & 1,41 & 2666,7 & 1,57 & 2729,2 & 1,57 \\
\hline 45. OC $79-84$ & 1291,7 & 1,41 & 2583,3 & 1,57 & 2312,5 & 1,41 \\
\hline 46. OC $79-136$ & 1166,6 & 1,41 & 2583,3 & 1,49 & 1979,2 & 1,41 \\
\hline 47. OC $79-230$ & 1604,2 & 1,41 & 1604,2 & 1,41 & 2312,5 & 1,41 \\
\hline 48. OC $79-493$ & 1458,3 & 1,41 & 2041,7 & 1,41 & 1437,5 & 1,41 \\
\hline 49. OC $79-504$ & 1229,2 & 1,41 & 2416,7 & 1,41 & 2250,0 & 1,49 \\
\hline 50. Pérola & 1437,5 & 1,41 & 2458,3 & 1,41 & 2208,3 & 1,41 \\
\hline 51. PI 332-694 & 916,7 & 1,41 & 2020,8 & 2,12 & 2437,5 & 2,34 \\
\hline 52. Pickett 71 & 520,8 & 1,41 & 1541,7 & 1,41 & 1812,5 & 1,41 \\
\hline 53. Santa Maria & 1145,8 & 2,00 & 1541,7 & $2,1.8$ & 1437,5 & 2,45 \\
\hline 54. SOC $81-76$ & 2291,7 & 1,49 & 2770,8 & 1,49 & 2416,7 & 1,49 \\
\hline 55. SOC $81-105$ & 2291,7 & 1,41 & 2958,3 & 1,49 & 2354,2 & 1,41 \\
\hline 56. SOC $81-119$ & 1812,5 & 1,41 & 2604,2 & 1,49 & 1770,8 & 1,41 \\
\hline 57. SOC $81-124$ & 1708,3 & 1,41 & 3250,0 & 1,41 & 1770,8 & 1,41 \\
\hline 58. SOC $81-145$ & 1687,5 & 1,49 & 2604,2 & 1,49 & 1895,8 & 1,41 \\
\hline 59. SOC $81-228$ & 1666,7 & 1,41 & 2854,2 & 1,49 & 2208,3 & 1,41 \\
\hline 60. Sulina & 1791,7 & 1,41 & 2833,3 & 1,41 & 2520,8 & 1,41 \\
\hline 61. Tiaraju & 1666,7 & 1,73 & 2375,0 & 1,98 & 2208,3 & 1,73 \\
\hline 62. TN $82-273$ & 437,5 & 1,41 & 562,5 & 1,41 & $1.541,7$ & 1,82 \\
\hline Mëclia & $1583 \div 40$ & $1,48 \pm 0,0001$ & $2479 \pm 48$ & $1,55^{+}-0,(1)$ & $2187 \pm 67$ & $1,57 \pm 0,02$ \\
\hline d.m.s. $(\%)$ & 1496 & 0,43 & 1797 & $\left.0,{ }_{4}^{4} 8\right\}$ & n.s. & 0,97 \\
\hline \multicolumn{7}{|l|}{ Testemunhas } \\
\hline $\mathrm{T}_{1} \cdot$ Bossier & 1562,0 & 1,41 & 2812,0 & 1,41 & 2979,0 & 1,41 \\
\hline $\mathrm{T}_{2} \cdot$ Davis & 1417,0 & 1,41 & 2812,0 & 1,41 & 1979,0 & 1,41 \\
\hline $\mathrm{T}_{3} \cdot \mathrm{IAC} 12$ & 2271,0 & 1,43 & 2625,0 & 1,61 & 2729,0 & 1,72 \\
\hline Mëdla & 1750,0 & 1,42 & 2750,0 & 1,48 & 2562,0 & 1,51 \\
\hline
\end{tabular}

$1_{1}=$ planta ereta; $5=$ planta prostrada

Dados transformados em $\sqrt{x+1}$.

d.m.s. : diferenga minima significativa, pelo teste de Tukey. 
TABELA 21. Análise conjunta dos caracteres produtividade (Prod.) e acamamento (Acam.), de 62 genótipos semi-precoces de soja, cultivados em campo, em três locais. Piracicaba, 1984/85.

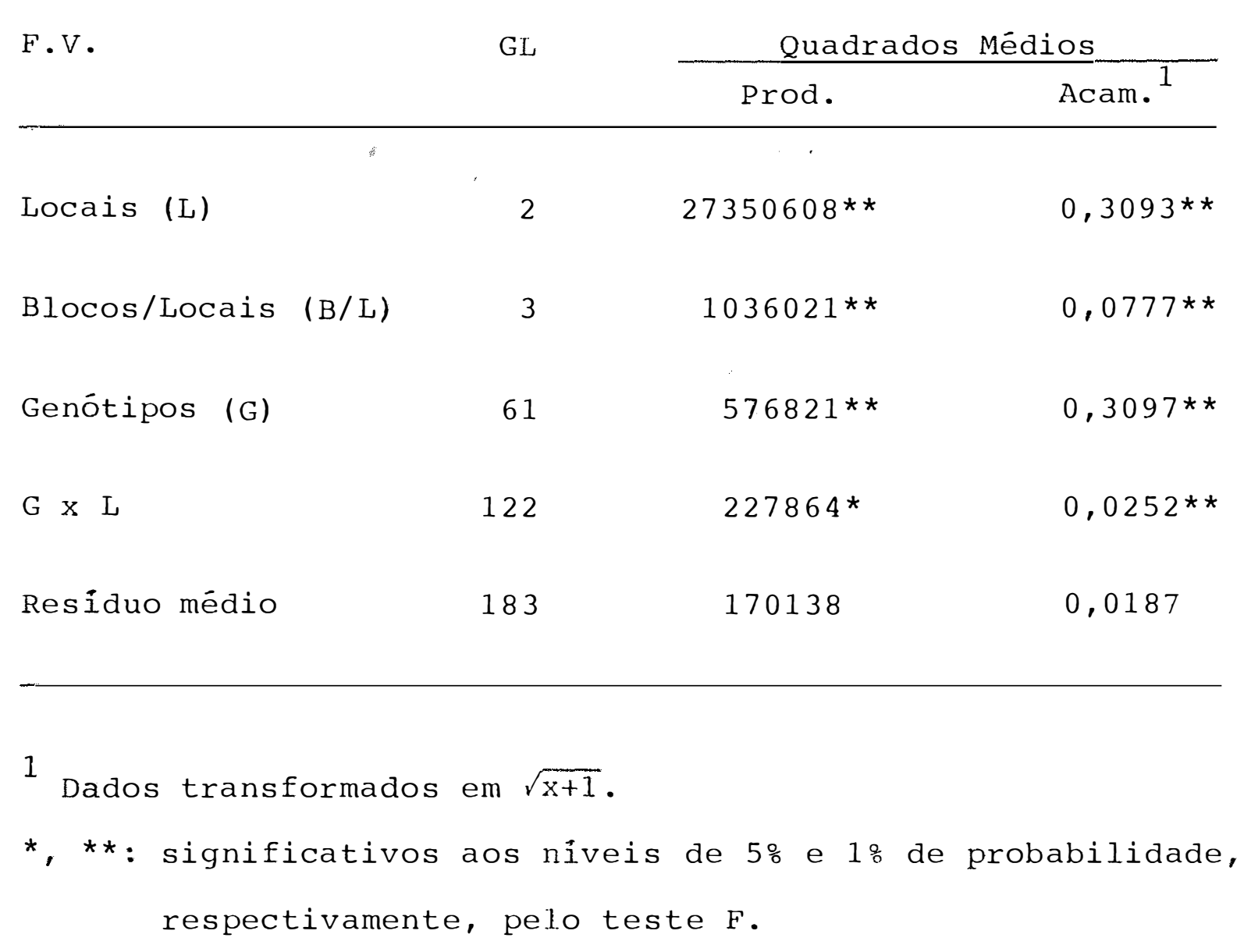


TABELA 22. Estimativas de coeficientes de correlação fenotipica $\left(r_{F}\right)$, ambiental $\left(r_{E}\right)$ e genotipica $\left(r_{G}\right)$, variāncia genotípica $\left(\mathrm{V}_{\mathrm{G}}\right)$ e coeficiente de determinação genotipica (b), dos caracteres peso seco de raizes (PSR) e da parte aérea (PSA), comprimento da raiz principal (CRP) e da parte aérea (CPA), para 62 genótipos semi-precoces de soja, cultivados em telado. Piracicaba, 1985.

\begin{tabular}{|c|c|c|c|c|c|}
\hline Caracteres & $r$ & PSR & PSA & CRP & $\mathrm{CPA}$ \\
\hline \multirow[t]{3}{*}{ PSR } & $F$ & & 0,508 & 0,442 & $-0,013$ \\
\hline & $\mathrm{E}$ & & 0,538 & 0,209 & $-0,121$ \\
\hline & G & & 0,497 & 0,765 & 0,920 \\
\hline \multirow[t]{3}{*}{ PSA } & $\mathrm{F}$ & & & 0,410 & 0,533 \\
\hline & $\mathrm{E}$ & & & 0,202 & 0,330 \\
\hline & G & & & 0,629 & 0,705 \\
\hline \multirow[t]{3}{*}{ CRP } & $\mathrm{F}$ & & & & 0,278 \\
\hline & $\mathrm{E}$ & & & & 0,017 \\
\hline & G & & & & 0,558 \\
\hline $\mathrm{V}_{\mathrm{G}}$ & & 0,000706 & 0,00384 & 4,2616 & 13,0941 \\
\hline $\mathrm{b}$ & & 0,438 & 0,615 & 0,403 & 0,577 \\
\hline
\end{tabular}


.125.

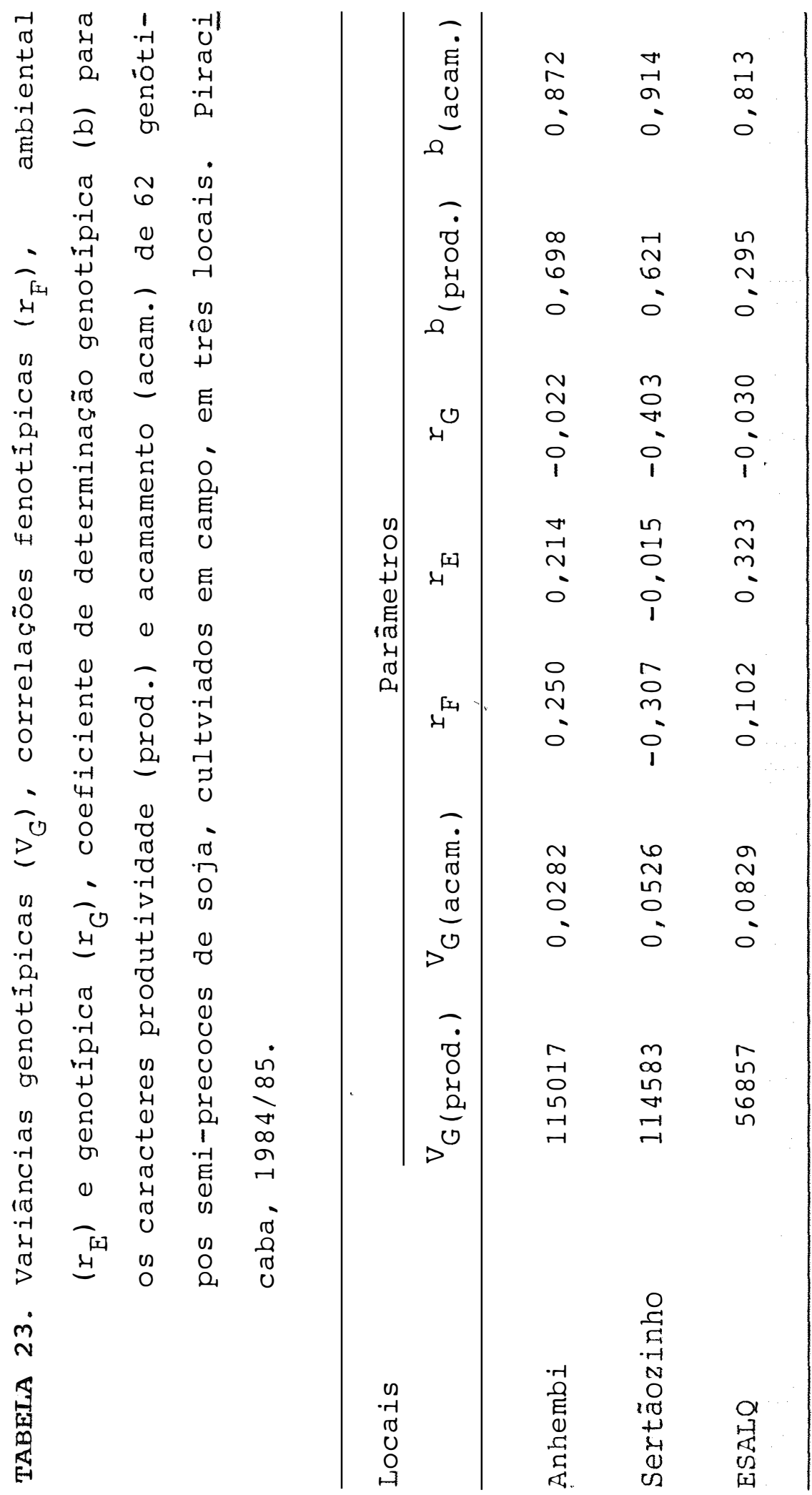




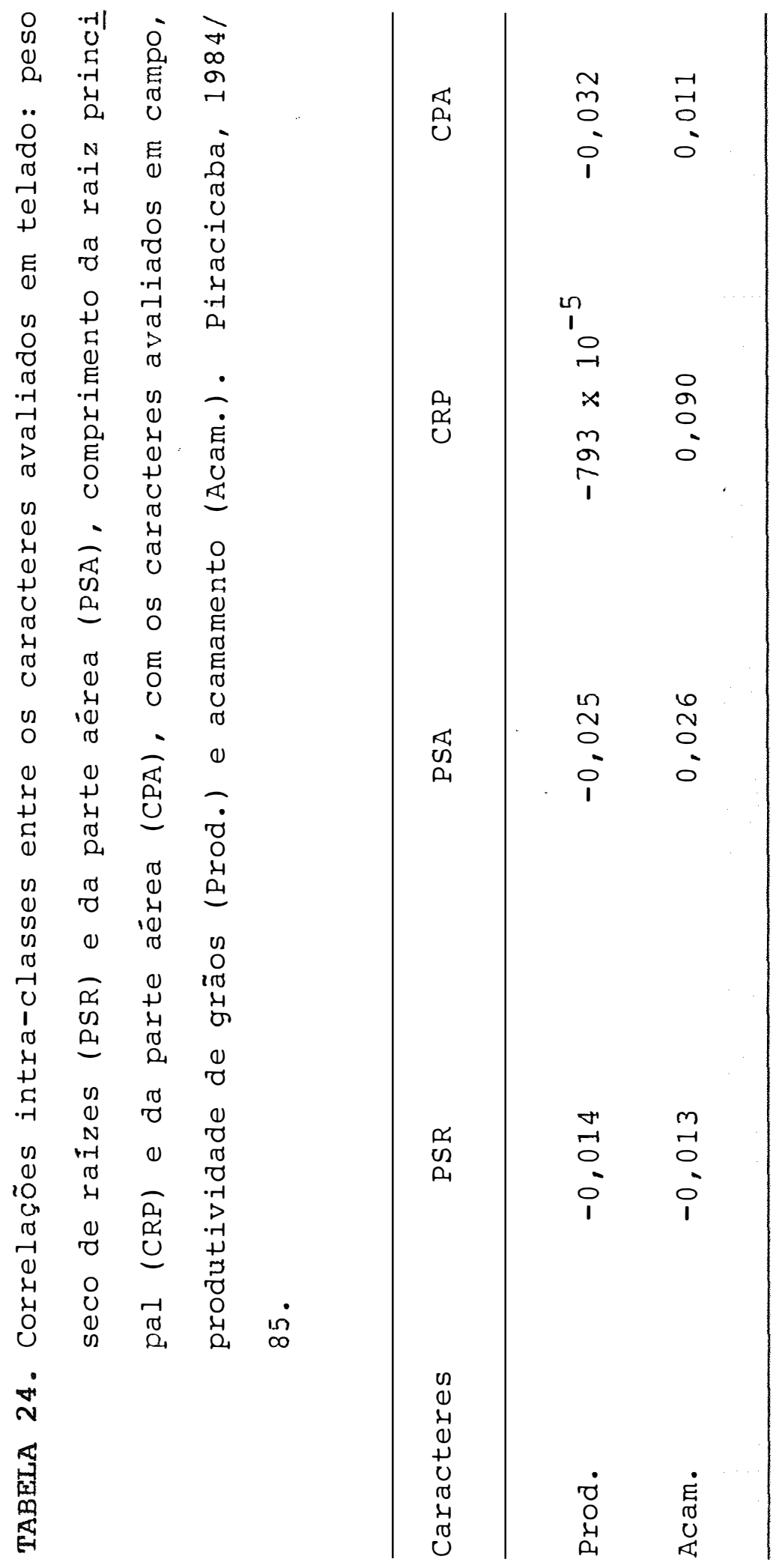


.127.

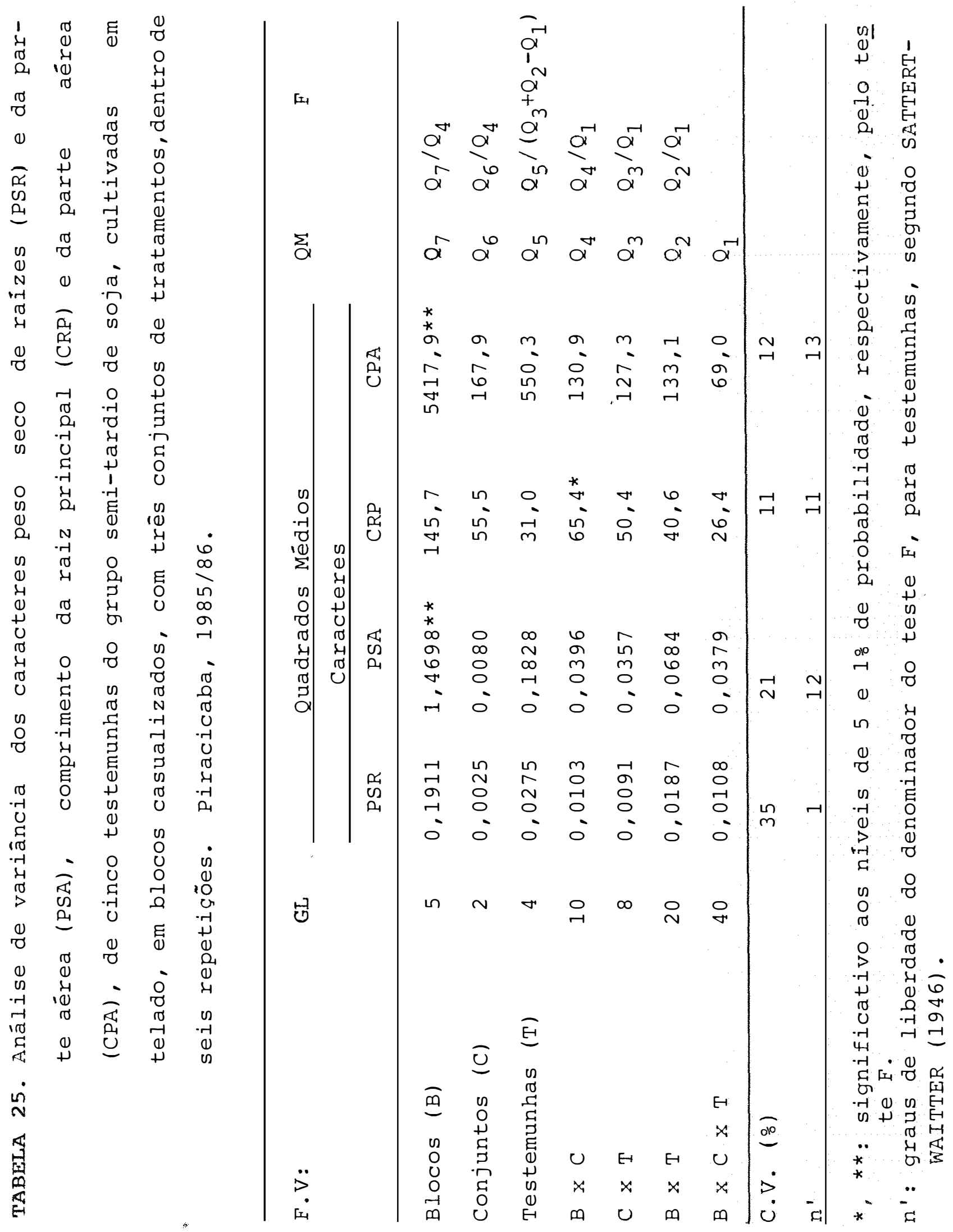


.128.

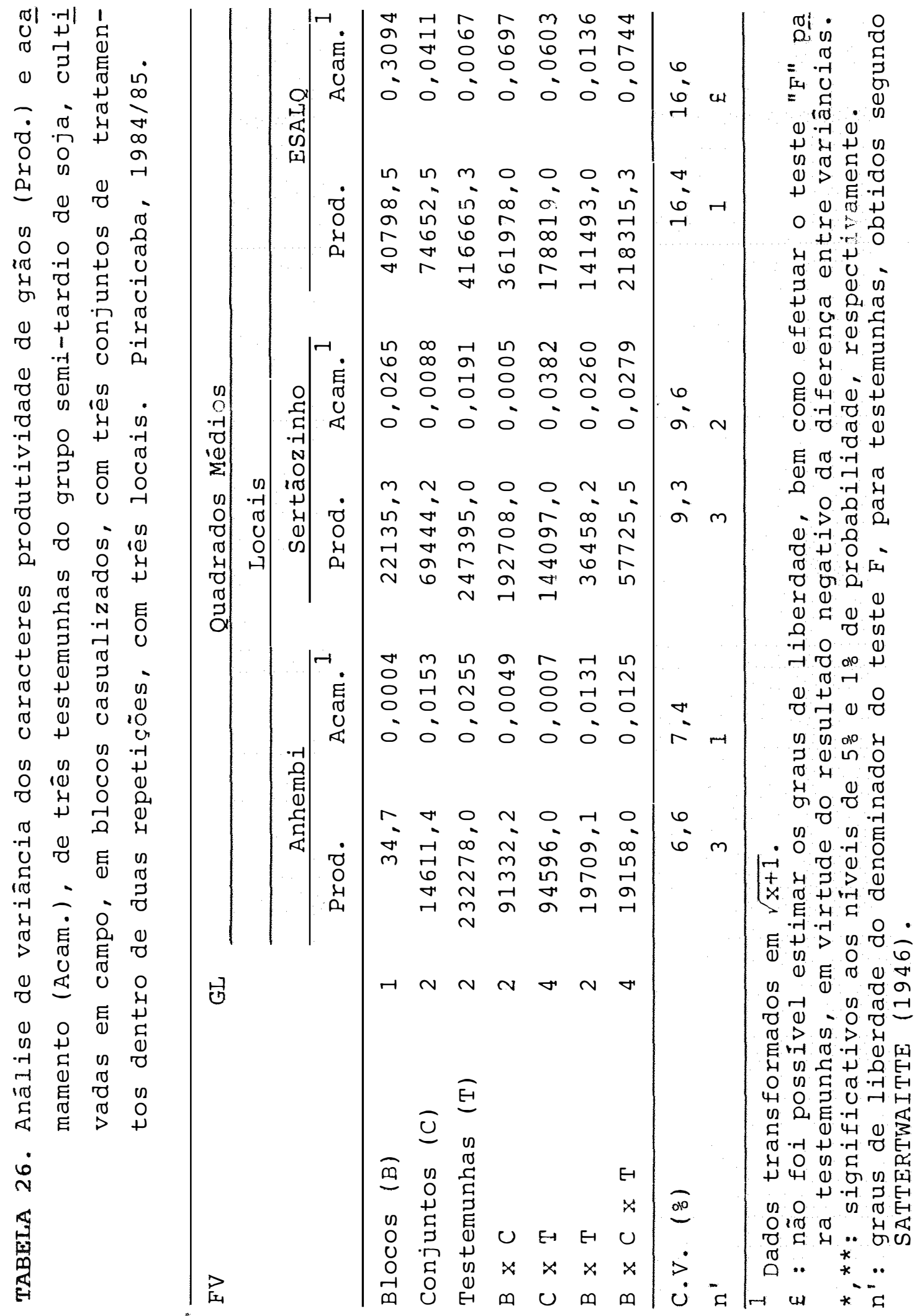


TABELA 27. Análise da variância para avaliações aos 30 dias pós-semeadura dos caracteres peso seco de raízes (PSR) e da parte aérea (PSA), comprimento da raiz principal ( $C R P$ ) e da parte aérea (CPA), de 44 genótipos semi-tardios de soja, cultivados em telado. Piracicaba, 1985/86.

\begin{tabular}{|c|c|c|c|c|c|}
\hline \multirow[t]{3}{*}{$\mathrm{F} \quad \mathrm{V}$} & \multirow[t]{3}{*}{ GL } & \multicolumn{4}{|c|}{ Quadrados Médios } \\
\hline & & \multicolumn{4}{|c|}{ Caracteres } \\
\hline & & PSR & PSA & $\mathrm{CRP}$ & $\mathrm{CPA}$ \\
\hline Blocos & 2 & 0,0677 & 0,7946 & 1172,81 & 939,85 \\
\hline Genótipos & 43 & $0,0230 \star \star$ & $0,0900 * *$ & 49,94 & $89,05 *$ \\
\hline Residuo & 86 & 0,0106 & 0,0380 & 57,51 & 63,06 \\
\hline $\mathrm{CV}$ (웅) & & 36 & 24 & 17 & 14 \\
\hline
\end{tabular}


TABELA 28. Análise da variância para avaliações aos 45 dias pós-semeadura dos caracteres peso seco de raizes (PSR) e da parte aérea (PSA), comprimento da raiz principal (CRP) e da parte aérea (CPA), de 44 genótipos semi-tardios de soja, cultivados em telado. Piracicaba, $1985 / 86$.

\begin{tabular}{|c|c|c|c|c|c|}
\hline \multirow[t]{3}{*}{$F \quad V$} & \multirow[t]{3}{*}{ GL } & \multicolumn{4}{|c|}{ Quadrados Médios } \\
\hline & & \multicolumn{4}{|c|}{ Caracteres } \\
\hline & & PSR & PSA & CRP & $\mathrm{CPA}$ \\
\hline Blocos & 2 & 1,1683 & 2,954 & 1221,93 & 12381,50 \\
\hline Genótipos & 43 & 0,0416 & 0,210 * & 48,07 & 264,21 \\
\hline Residuo & 86 & 0,0300 & 0,134 & 76,80 & 202,66 \\
\hline $\mathrm{CV} \quad(\%)$ & & 42 & 29 & 18 & 17 \\
\hline
\end{tabular}

*, ** : significativo ao nivel de $5 \%$ e $1 \%$ de probabilidade, respectivamente, pelo teste $F$. 


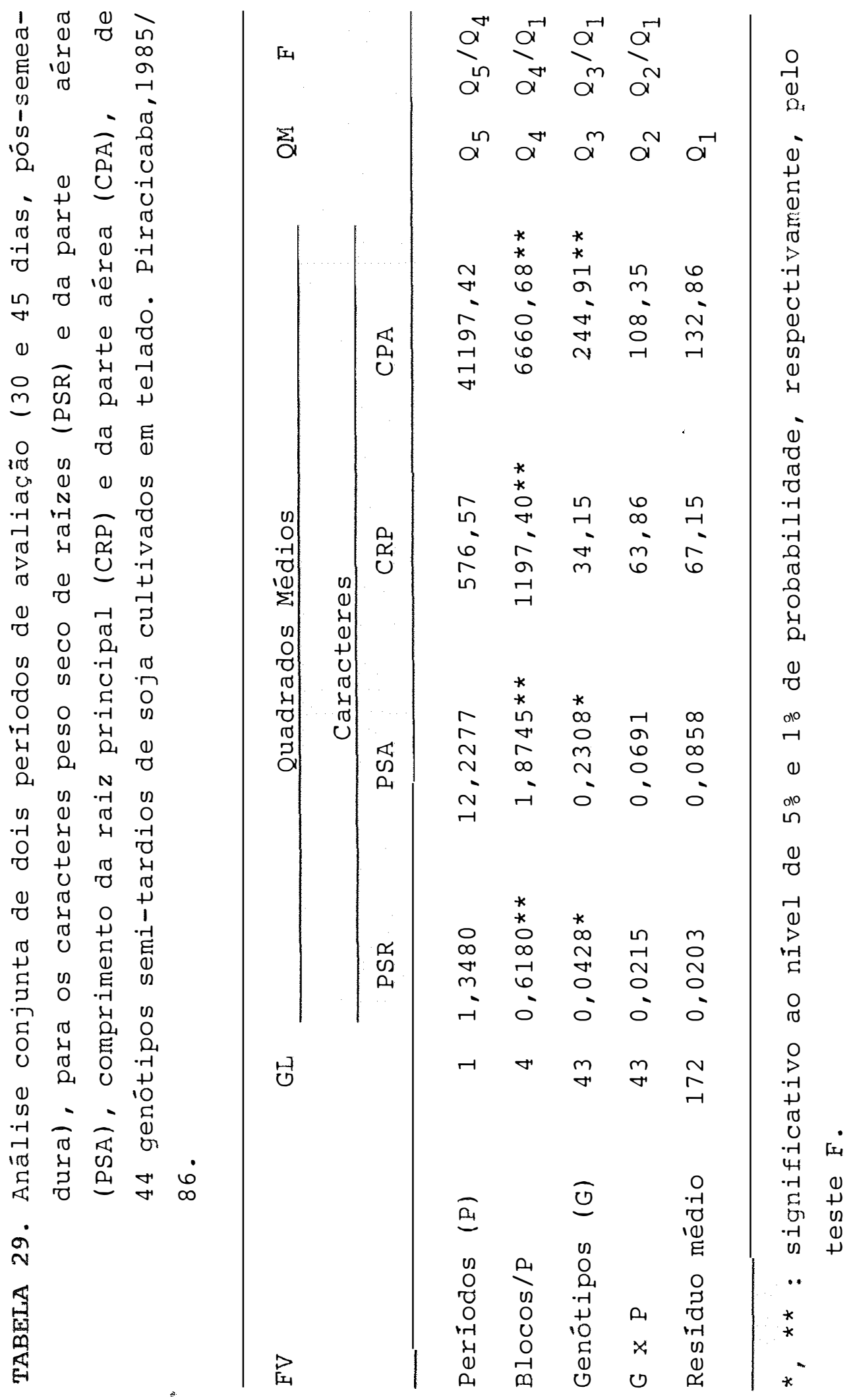


TABEL.A 30. Análise da variância, coeficiente de variação experimental (CV) e coeficiente de variação genotípica $\left(\mathrm{CV}_{\mathrm{G}}\right)$ para os caracteres peso seco de raizes (PSR) e da parte aérea (PSA), comprimento da raiz principal (CRP) e da parte aérea (CPA), de 44 genótipos semi-tardios de soja, cultivados em telado. Piracicaba, $1985 / 86$.

\begin{tabular}{|c|c|c|c|c|c|}
\hline & \multirow[t]{3}{*}{ GL } & \multicolumn{4}{|c|}{ Quadrados Médios } \\
\hline & & \multicolumn{4}{|c|}{ Caracteres } \\
\hline & & PSR & PSA & CRP & CPA \\
\hline Blocos & & 0,7412 & 0,47001 & 645,9 & 15094,40 \\
\hline Genótipos & & $0,0318 * *$ & 0,1546 ** & 45,9 & $213,7 * *$ \\
\hline Residuo & & 0,0204 & 0,0751 & 40,9 & 131,6 \\
\hline $\mathrm{CV}$ (응 & & 41,0 & 26,8 & 13,3 & 16,4 \\
\hline$C V_{G}\left(\frac{o}{\partial}\right)$ & & 12,5 & 11,3 & 1,7 & 5,3 \\
\hline
\end{tabular}

** : significativo ao nivel de 1응 de probabilidade, pelo tes te $F$. 
TABELA 31. Médias de seis repetiçōes para os caracteres peso seco de raízes (PSR) e da parte aẻrea (PSA), comprimentc da raiz principal (CRP) e da parte aérea (CPA), de 4.4 genotipos semi-tardios de soja, cultivados em telado. Plracicaba, $1985 / 86$.

\begin{tabular}{|c|c|c|c|c|}
\hline \multirow[t]{2}{*}{ Cenotlpos } & \multicolumn{4}{|c|}{ Catacteres } \\
\hline & \multicolumn{2}{|c|}{ g/planta } & \multicolumn{2}{|c|}{$\mathrm{cm} / p$ lanta } \\
\hline 01. Andrews & 0,34 & 0,98 & 51,6 & 72,1 \\
\hline 02. Avaré & 0,25 & 0,85 & 43,2 & 72,2 \\
\hline 03. BR 5 & 0,40 & 1,26 & 51,6 & 82,7 \\
\hline 04. CEPS 10 & 0,35 & 0,98 & 46,7 & 58,6 \\
\hline 05. De1ta $=$ IAS -3 & 0,32 & 1,11 & 46,5 & 75,9 \\
\hline 06. Dourados & 0,38 & 1,16 & 46,8 & 75,3 \\
\hline 07. FI 8 & 0,48 & 1,14 & 49,9 & 67,7 \\
\hline 08. FT 10 & 0,24 & 0,83 & 45,5 & 70,8 \\
\hline 09. Ga 78-2708 & 0,30 & 0,88 & 51,3 & 68,1 \\
\hline 10. Gaúcha & 0,36 & 0,95 & 48,6 & 60,3 \\
\hline 11. GO $81-8065$ & 0,29 & 0,91 & 51,9 & 67,8 \\
\hline 12. GO 79-7011 & 0,31 & 1,01 & 47,1 & 75,2 \\
\hline 13. GO $79 \cdots 7012$ & 0,31 & 0,96 & 46,7 & 64,4 \\
\hline 14. GO 79-1030 & 0,32 & 0,91 & 50,9 & 74,0 \\
\hline 15. GO $81-11031$ & 0,39 & 0,94 & 45,5 & 59,4 \\
\hline 16. GO $81-11081$ & 0,38 & 0,99 & 44,1 & 75,3 \\
\hline 17. GO $81-11094$ & 0,39 & $1,1.0$ & 48,9 & 69,9 \\
\hline 18. G0 81-11103 & 0,43 & 1,08 & 50,8 & 66,3 \\
\hline 19. Himpton & 0,37 & 1,08 & 47,0 & 66,4 \\
\hline 20. Hardee & 0,47 & 1,15 & 47,8 & 71,2 \\
\hline 21. IAC 3 & 0,38 & 1,07 & 48,4 & 73,6 \\
\hline $22 \cdot \operatorname{IAC} 4$ & 0,28 & 0,92 & 49,5 & 71,0 \\
\hline
\end{tabular}

\begin{tabular}{ll}
\hline Genótipos & \multicolumn{3}{c}{ Caracteres } \\
\cline { 2 - 3 } & PSR $\quad$ PSA $\quad$ CRP CPA \\
g/planta & $\mathrm{cm} / \mathrm{planta}$ \\
\hline
\end{tabular}

23. IAC $5 \quad 0,57 \quad 1,19 \quad 57,0 \quad 61,5$

24. IAC $6 \quad 0,36 \quad 1,10 \quad 47,2 \quad 73,9$

25. IAC 7

$0,27 \quad 0,70 \quad 48,7 \quad 63,8$

26. IAC $10 \quad 0,31 \quad 0,96 \quad 49,1 \quad 58,9$

27. IAC $12 \quad 0,27 \quad 0,91 \quad 45,7 \quad 70,2$

28. Industrial $0,37 \quad 1,12 \quad 48,3 \quad 67,0$

29. La 76-1459 0,31. 1,02 48,0 80,2

30. Mineira $0,32 \quad 0,96 \quad 55,4 \quad 64,3$

31. Nova Sta.Rosa 0,26 0,78 47,2 73,9

32. Paranagoiana $0,38 \quad 0,96 \quad 50,9 \quad 57,8$

33. S $66 \quad 0,44 \quad 1,38 \quad 45,0 \quad 69,2$

34. Santa Rosa $0,30 \quad 0,8945,8 \quad 73,0$

35. Sta.Rosa-verde $0,23 \quad 0,84 \quad 46,7 \quad 73,8$

36. Sảo Luiz $0,54 \quad 1,56 \quad 50,5 \quad 68,2$

37. Savana $0,45 \quad 1,12 \quad 52,0 \quad 65,4$

38. SoC: $81-169 \quad 0,36 \quad 1,09 \quad 44,8 \quad 71,0$

39. $\operatorname{SOC} 81-216 \quad 0,33 \quad 0,99 \quad 4 i_{4}, 2 \quad 72,6$

40. $\operatorname{SOC} 81-266 \quad 0,27 \quad 0,84 \quad 44,1 \quad 77,2$

41. Tiaraju $0,27 \quad 0,79$ 4,1 76,9

42. UFV $4 \quad 0,32 \quad 1,12 \quad 45,4 \quad 64,8$

43. Viçoja $0,29 \quad 1,1150,4 \quad 77,8$

44. Yelmanda $0,39 \quad 1,17 \quad 49,7 \quad 70,5$

Mēdia

$0,351,02 \quad 48,1 \quad 69,8$

$0,02 \quad 1,0 \quad 1,7$

d. In.s. $(1 \%)$

$0,360,70 \quad-29,3$

Testemunhas

$\mathrm{T}_{1}$, IAC 10

$0,31 \quad 0,81 \quad 47,4 \quad 62,2$

$\mathrm{T}_{4} \cdot$ IAC-Foscarin-

$\mathrm{T}_{2} \cdot$ IAC 1.1

$0,330,96 \quad 49,2 \quad 67,8$

$-31$

$0,35 \quad 1,05 \quad 47,1 \quad 70,1$

$\mathrm{T}_{3} \cdot \mathrm{IAC} 12$

$0,26 \quad 0,82 \quad 47,9 \quad 63,5$

$\mathrm{I}_{5}$, Tropical.

$0,270,9549,0 \quad 76,0$

Médla

$0,30 \quad 0,92 \quad 48,1 \quad 67,9$

d.m.s. : diferença mínima significativa, pelo teste de Tukey. 


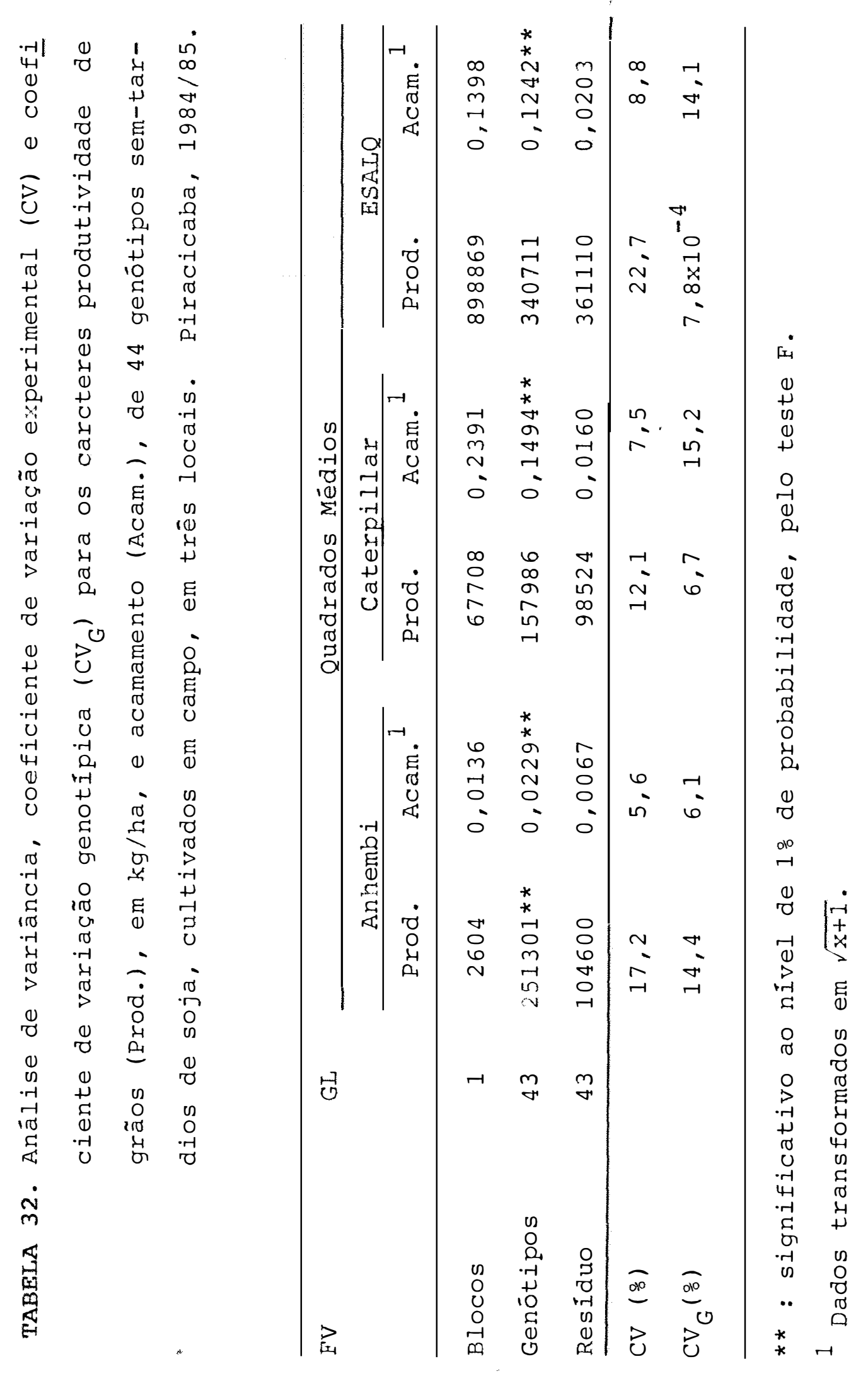


TABELA 33. Médias de duas repetiçōes para os caracteres produtividade de gräos (Prod.) e acamamento (Acam.), de 44 genótipos semi-tardios de soja, cultívados em campo, em trēs locais. Piracicaba, 1984/85.

\begin{tabular}{|c|c|c|c|c|c|c|}
\hline \multirow[t]{3}{*}{ Genōtipos } & \multicolumn{6}{|c|}{ Locais } \\
\hline & \multicolumn{2}{|c|}{ Anhembi } & \multicolumn{2}{|c|}{ Sertäozinho } & \multicolumn{2}{|c|}{ RSALQ } \\
\hline & $\begin{array}{l}\text { Prod. } \\
\mathrm{kg} / \mathrm{ha}\end{array}$ & $\begin{array}{l}\Lambda c a m . \\
\left(\begin{array}{lll}1 & \text { a } & 5\end{array}\right)\end{array}$ & $\begin{array}{l}\text { Prod. } \\
\mathrm{kg} / \mathrm{ha}\end{array}$ & $\begin{array}{c}\text { Acall. } \\
\left(\begin{array}{lll}1 & \text { a } & 5\end{array}\right)\end{array}$ & $\begin{array}{l}\text { Prod. } \\
\mathrm{kg} / \mathrm{ha}\end{array}$ & $\begin{array}{l}\text { Acam. } \\
\left(\begin{array}{lll}1 & \text { a }\end{array}\right) \\
\end{array}$ \\
\hline 01. Andrews & 2125 & 1,41 & 2479 & 1,92 & 2500 & 1,62 \\
\hline 02. Avaré & 1708 & 1,41 & 2562 & 1,41 & 1771 & 1,41 \\
\hline 03. BR 5 & 1708 & 1,41 & 2375 & 1,41 & 2208 & 1,41 \\
\hline 04. CEPS & 1500 & 1,41 & 2375 & 1,41 & 2625 & 1,41 \\
\hline 05. Delta $=$ IAS -3 & 2125 & 1,41 & 2854 & 1,41 & 2229 & 1,41 \\
\hline 06. Dourados & 1708 & 1,41 & 2583 & 1,88 & 2812 & 1,49 \\
\hline 07. FT 8 & 1833 & 1,41 & 2979 & $1,4\}$ & 3479 & 1,41 \\
\hline 08. DR 10 & 1521 & 1,41 & 2792 & $1,4+1$ & 2917 & $1,4.1$ \\
\hline 09. Ga 78-2708 & 792 & $1,4.1$ & 2375 & $1,4,1$ & 1854 & 1,41 \\
\hline 10. Gaúcha & 1708 & 1,41 & 2583 & 1,56 & 2125 & 1,41 \\
\hline 11. G0 79-7011 & 2021 & 1,72 & 2479 & 1,86 & 3083 & 1,72 \\
\hline 12. GO 79-7012 & 1396 & 1,49 & 2562 & 2,12 & 2146 & $1 ., 85$ \\
\hline 13. GO 79-1030 & 2042 & 1,73 & 2417 & 2,06 & 3396 & 1,73 \\
\hline 14. GO 81-8065 & 2104 & 1,41 & 2625 & 1,72 & 2833 & 1,65 \\
\hline 15. G0 81-11031 & 1792 & 1,41 & 2750 & 1,72 & 2812 & $x, 72$ \\
\hline 16. GO 81-11081. & 1812 & 1,62 & 2021 & 2,24 & 2833 & 2,40 \\
\hline 17. GO 81-11.094 & 2.225 & 1,55 & 2750 & 2,23 & 2604 & 2,23 \\
\hline 18. GO $81-11103$ & 2000 & 1,41 & 2396 & 1,86 & 3229 & 1,55 \\
\hline 19. Hampton & 1458 & 1,41 & 2646 & 1,41 & 2208 & 1,41 \\
\hline 20. Hardee & 1250 & 1,41 & 2667 & 1,41 & 2750 & 1,41 \\
\hline 21. IAC 3 & 1792 & 1,49 & 2250 & 1,73 & 3062 & 1,93 \\
\hline 22. IAC 4 & 1708 & 1,41 & 2646 & 1,63 & 2729 & 1,70 \\
\hline 23. IAC 5 & 1896 & 1,55 & 2000 & 2,12 & 2979 & 1,85 \\
\hline 24. IAC 6 & 2167 & 1,85 & 2229 & 2,29 & 2792 & 2,18 \\
\hline 25. IAC 7 & 2062 & 1,41 & 2437 & 1,65 & 2771 & 1,49 \\
\hline 26. IAC 10 & 1750 & 1,52 & 2271 & 1,97 & 2667 & 1,96 \\
\hline 27. IAC 12 & 2417 & 1,62 & 2458 & 1,97 & 2250 & 1,61 \\
\hline 28. Industrial & 2021 & 1,41 & 2396 & 1,61 & 2250 & 1,41 \\
\hline 29. Lo 76.1459 & 1521 & 1,41 & 2812 & 1,65 & 2729 & 1,55 \\
\hline 30. Mineira & 2187 & 1,41 & 2437 & 1,41 & 2583 & 1,49 \\
\hline 31. Nova Santa Rosa & 1958 & 1,57 & 2500 & 2,00 & 2771 & 1,80 \\
\hline 32. Paranagoiana & 2354 & 1,60 & 2937 & 1,86 & 2729 & 1,49 \\
\hline 33. S 66 & 1208 & 1,41 & 2771 & 1,41 & 1979 & 1,41 \\
\hline 34. Santa Rosa & 1958 & 1,41 & 2500 & 1,79 & 2667 & 1,62 \\
\hline 35. Santa Rosa (verde) & 1896 & 1,41 & 2375 & 1,68 & 2417 & 1,70 \\
\hline 36. São Luiz & 1958 & 1,41 & 2645 & 1,41 & 3062 & 1,41 \\
\hline 37. Savana & 2500 & 1,57 & 3083 & 1,65 & 2812 & 2,00 \\
\hline 38. SOC $81-169$ & 1667 & 1,41 & $24+17$ & 1,41 & 2292 & $2,4.1$ \\
\hline 39. SOC $81-216$ & 1500 & 1,41 & 3417 & $1,4,1$ & 2687 & 1,72 \\
\hline 40. SOC $81-266$ & 2396 & 1,41 & 2229 & 1,57 & 2333 & 1,41 \\
\hline 41. Tiarajü & 2083 & 1,41 & 2312 & 1,86 & 2437 & 1,49 \\
\hline 42. UFV 4 & 2187 & $1,4,1$ & 2521 & 1,68 & 3271 & 1,65 \\
\hline 43. Viçoja & 1521 & 1,41 & 2687 & 1,41 & 3521 & 1,49 \\
\hline 44. Yelmanda & 1812 & 1,41 & 2646 & 1,49 & 2561 & 1,41 \\
\hline Média & $1875 \pm 0,03$ & $1,47 \pm 0,01$ & $2583 \pm 0,02$ & $1,69 \pm 0,02$ & $2654 \div 0,04$ & $1,62 \pm 0,02$ \\
\hline d.m.s. $(\%)$ & 1521 & 0,39 & $\mathrm{~ns}$ & 0,60 & ns & 0,67 \\
\hline \multicolumn{7}{|l|}{ Testemunhas } \\
\hline $\mathrm{T}_{1} \cdot 1 \mathrm{AC}: 8$ & 1854 & 1,52 & 2646 & 1,71 & 3167 & 1,68 \\
\hline $\mathrm{T}_{2} \cdot \mathrm{IAC} 10$ & 22.08 & 1,57 & 2375 & 1,72 & 2729 & 1,61 \\
\hline $\mathrm{T}_{3} \cdot$ IAC 11 & 2167 & 1,41 & 2750 & 1,81 & 2667 & 1,63 \\
\hline Média & 2083 & 1,50 & 2583 & 1,75 & 2854 & 1,64 \\
\hline
\end{tabular}

$1_{1}=$ planta ereta; 5 = planta prostrada

Dados transformados em $\sqrt{\mathrm{x}+1}$.

d.m.s. : diferença mínima significativa pelo teste de Tukey. 
TABELA 34. Análise conjunta dos caracteres produtividade de grãos (Prod.) e acamamento (Acam.), de 44 genótipos semi-tardios de soja, cultivados em campo, em três locais. Piracicaba, 1984/85.

\begin{tabular}{|c|c|c|c|c|c|}
\hline \multirow[t]{2}{*}{$\mathrm{F} \quad \mathrm{V}$} & \multirow[t]{2}{*}{ GL } & \multicolumn{2}{|c|}{ Quadrados Médios } & \multirow[t]{2}{*}{$\mathrm{QM}$} & \multirow[t]{2}{*}{$\mathrm{F}$} \\
\hline & & Prod. & Acam. ${ }^{1}$ & & \\
\hline Locais (L) & 2 & 16341962 ** & 1,1537 & $Q_{5}$ & $Q_{5} / Q_{1}$ \\
\hline $\mathrm{Blocos} / \mathrm{L}$ & 3 & 330728 & $0,1308 * *$ & $Q_{4}$ & $Q_{4} / Q_{1}$ \\
\hline Genótipos (G) & 43 & 330728 ** & $0,2205 * *$ & $Q_{3}$ & $\mathrm{Q}_{3} / \mathrm{Q}_{1}$ \\
\hline$G \times L$ & 86 & 290635 & $0,0380 * *$ & $\mathrm{Q}_{2}$ & $\mathrm{Q}_{2} / \mathrm{Q}_{1}$ \\
\hline Resíduo médio & 129 & 188367 & 0,0143 & $Q_{1}$ & \\
\hline
\end{tabular}

** : significativo ao nível de 1 \% de probabilidade, pelo tes te $F$.

1 Dados transformados em $\sqrt{\mathrm{x}+1}$. 
TABELA 35. Estimativas de coeficientes de correlação fenotípica $\left(r_{F}\right)$, ambiental $\left(r_{E}\right)$ e genotipica $\left(r_{G}\right)$, variância genotipica $\left(\mathrm{V}_{\mathrm{G}}\right)$ e coeficiente de determinação genotípica (b), dos caracteres peso seco de raizes (PSR) e da parte aérea (PSA), comprimento da raiz principal (CRP) e da parte aérea (CPA), de 44 genótipos semi-tardios de soja, cultivados em telado. Piracicaba, 1985/86.

\begin{tabular}{|c|c|c|c|c|c|}
\hline Caracteres & $r$ & PSR & PSA & $\mathrm{CRP}$ & CPA \\
\hline \multirow[t]{3}{*}{ PSR } & $\mathrm{F}$ & & 0,815 & 0,348 & $-0,272$ \\
\hline & $\mathrm{E}$ & & 0,694 & 0,320 & $-0,296$ \\
\hline & G & & 0,996 & 0,570 & $-0,231$ \\
\hline \multirow[t]{3}{*}{ PSA } & $\mathrm{F}$ & & & 0,221 & 0,022 \\
\hline & $\mathrm{E}$ & & & 0,392 & $-0,024$ \\
\hline & G & & & $-0,182$ & 0,079 \\
\hline \multirow[t]{3}{*}{ CRP } & $\mathrm{F}$ & & & & $-0,232$ \\
\hline & $\mathrm{E}$ & & & & $-0,198$ \\
\hline & G & & & & $-0,450$ \\
\hline $\mathrm{v}_{\mathrm{G}}$ & & 0,00189 & 0,0132 & 0,688 & 13,675 \\
\hline b & & 0,357 & 0,514 & 0,0916 & 0,384 \\
\hline
\end{tabular}



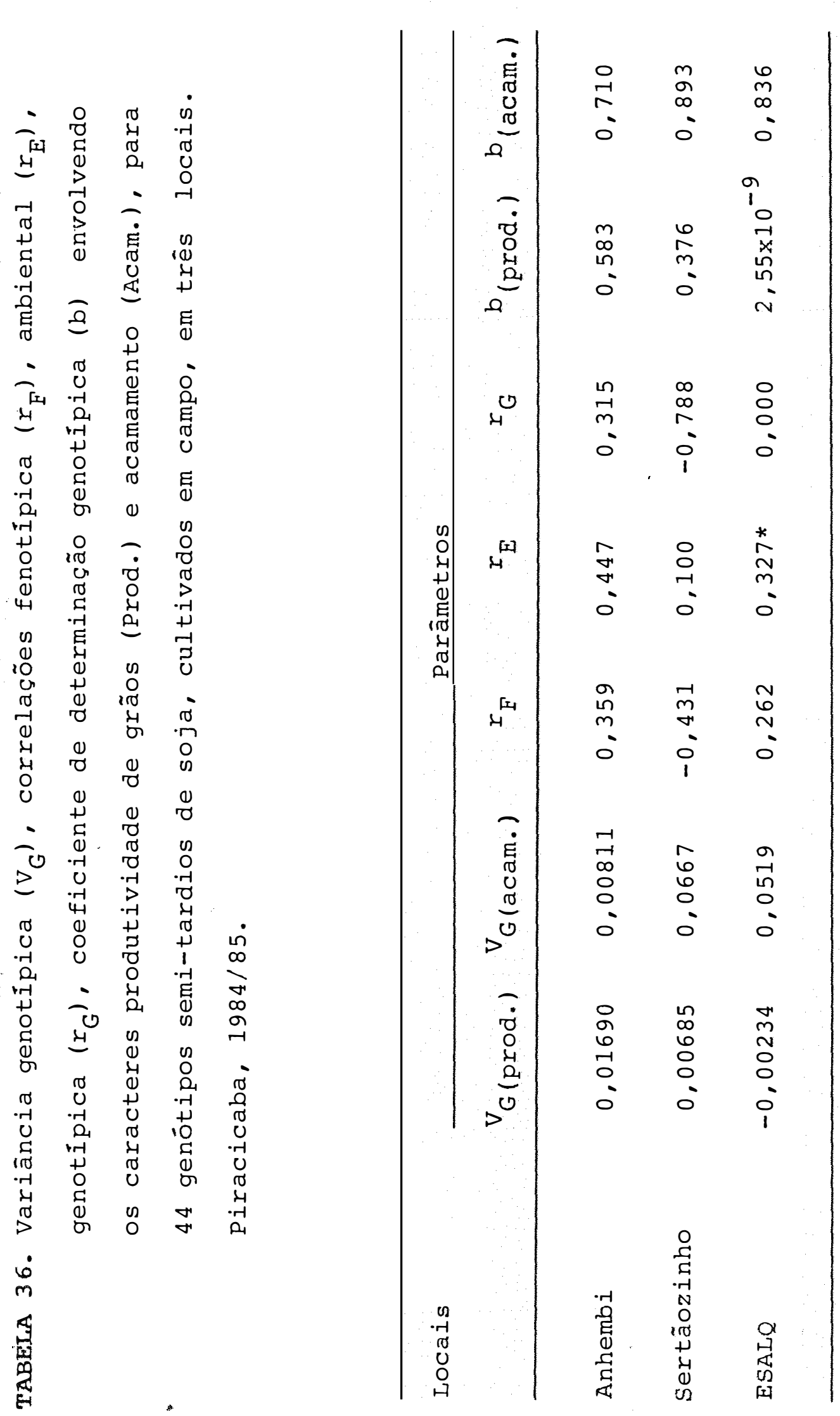

.138. 
.139.

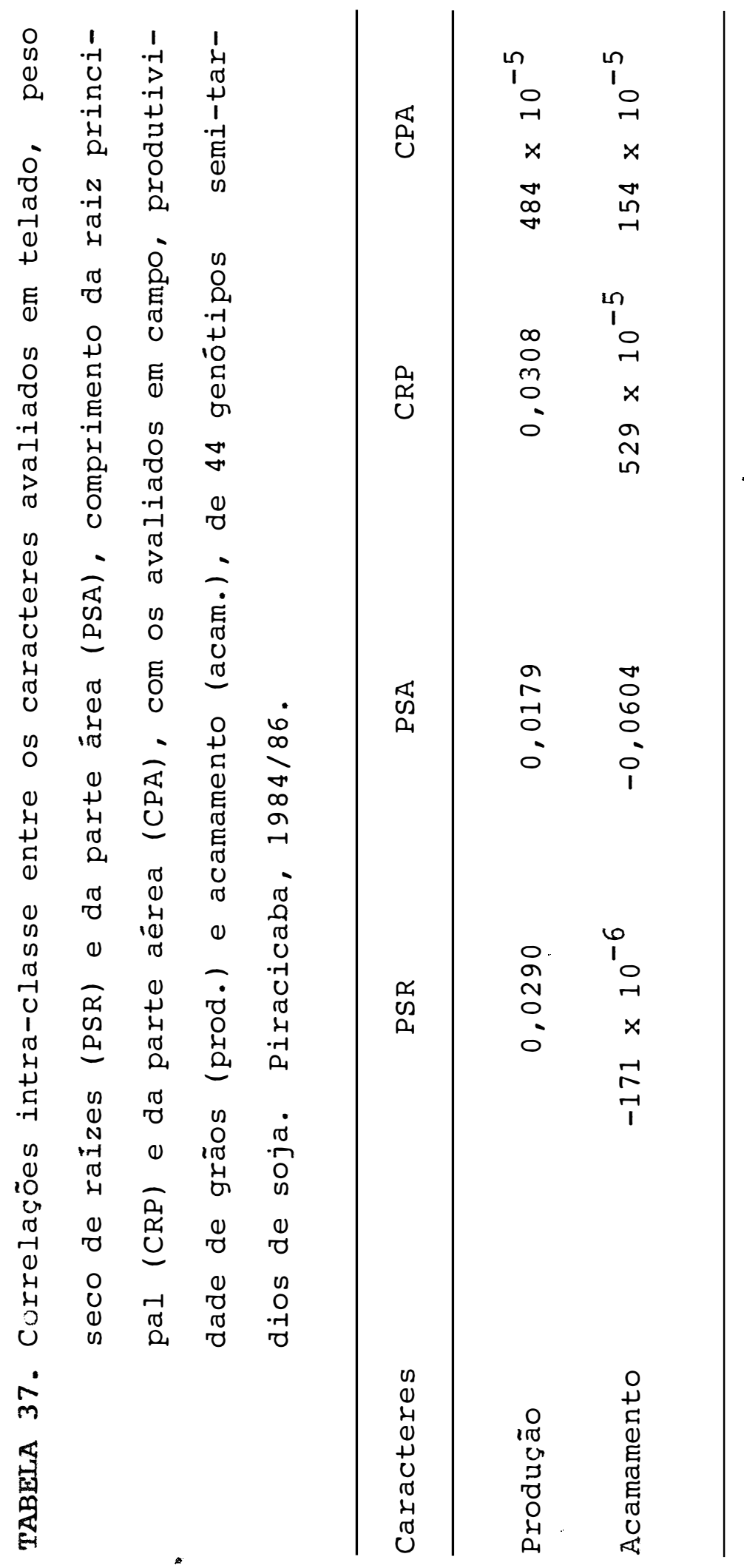


.140.

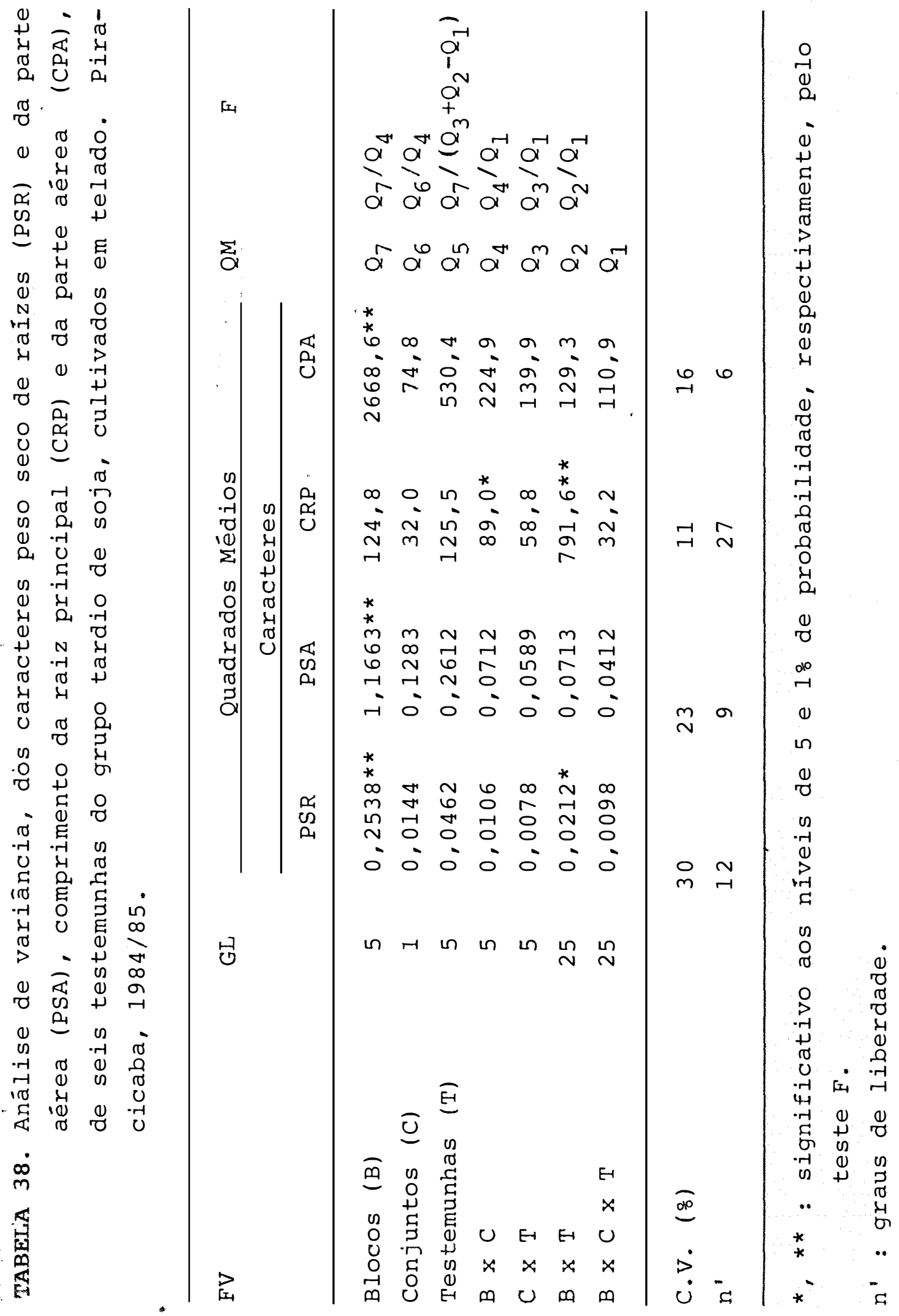


.141.

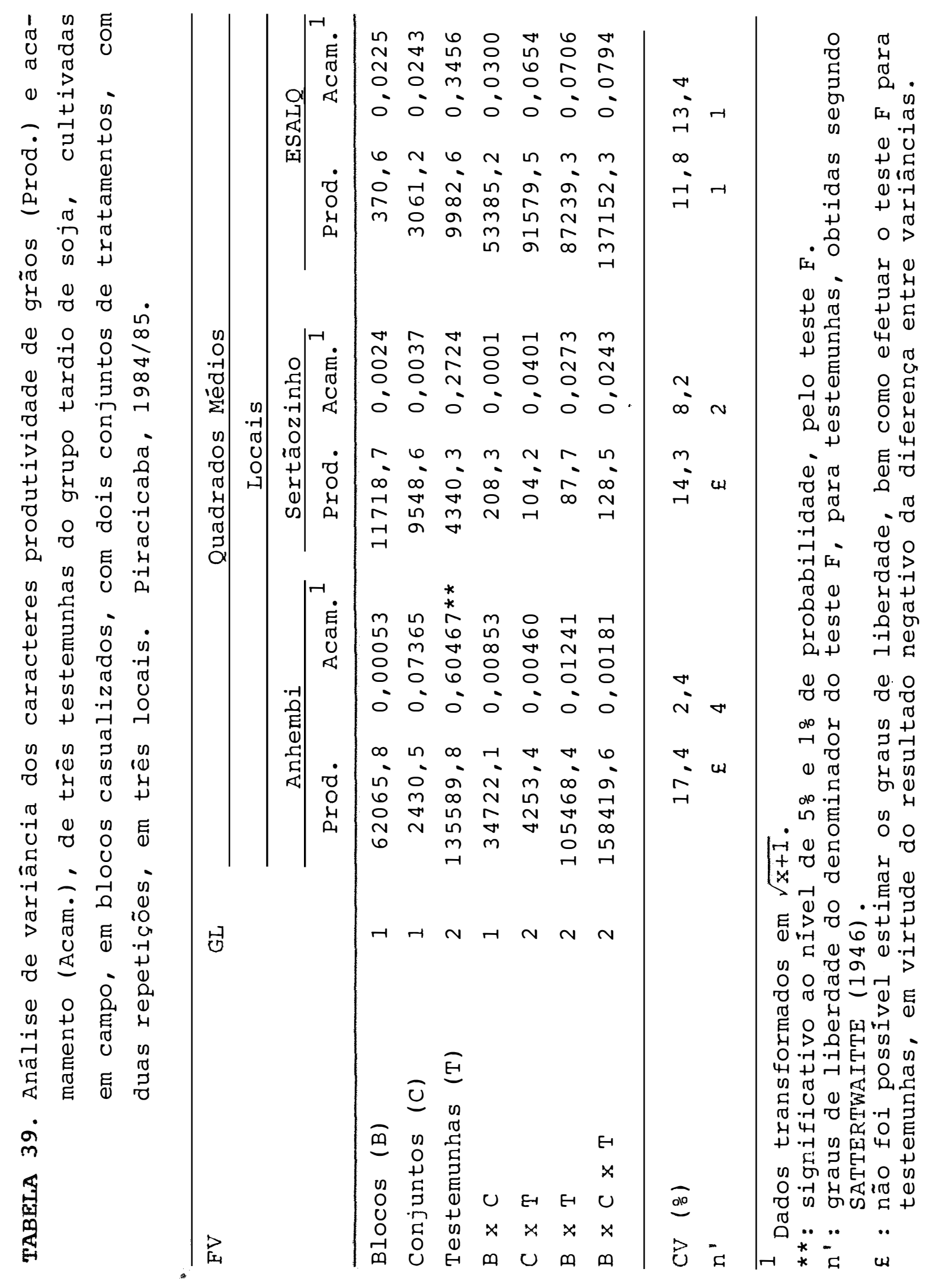


TABELA 40. Análise da variāncia para avaliações aos 30 dias pós-semeadura, dos caracteres peso seco de raízes (PSR) e da parte aérea (PSA), comprimento da raiz principal (CRP) e da parte aérea (CPA), de 16 genótipos tardios de soja, cultivados em telado. Pi racicaba, 1986 .

\begin{tabular}{lrcrrr}
\hline FV & \multirow{2}{*}{ GL } & \multicolumn{4}{c}{ Quadrados Médios } \\
\cline { 3 - 6 } & & \multicolumn{4}{c}{ Caracteres } \\
\cline { 2 - 6 } & 2 & 0,0483 & 0,0644 & 186,02 & 1753,44 \\
\hline Blocos & 15 & 0,0127 & 0,0292 & 42,75 & 162,28 \\
Genótipos & 30 & 0,0077 & 0,0237 & 36,10 & 86,28 \\
Resíduo & & 32 & 24 & 11 & 16 \\
\hline CV (ㅇyy & & & & &
\end{tabular}

TABELA 41. Análise da variância para avaliações aos 45 dias pós-semeadura, dos caracteres peso seco de raízes (PSR) e da parte aérea (PSA), comprimento da raiz principal (CRP) e da parte aérea (CPA), de 16 genótipos tardios de soja, cultivados em telado. Pí racicaba, 1986 .

\begin{tabular}{|c|c|c|c|c|c|}
\hline \multirow[t]{3}{*}{$\mathrm{FV}$} & \multirow[t]{3}{*}{ GL } & \multicolumn{4}{|c|}{ Quadrados Médios } \\
\hline & & \multicolumn{4}{|c|}{ Caracteres } \\
\hline & & PSR & PSA & $\mathrm{CRP}$ & $\mathrm{CPA}$ \\
\hline Blocos & 2 & 0,2953 & 0,0950 & 30,68 & 3580,91 \\
\hline Genótipos & 15 & $0,0957 * *$ & 0,1820 & 35,64 & $402,24 *$ \\
\hline Residuo & 30 & 0,0395 & 0,1157 & 32,95 & 177,30 \\
\hline $\mathrm{CV} \quad\left(\frac{\circ}{0}\right)$ & & 41 & 30 & 11 & 17 \\
\hline
\end{tabular}


TABELA 42. Análise conjunta para as duas épocas de avaliações (30 e 45 dias pós-semeadura), para os caracteres peso seco de raízes (PSR) e da parte aérea (PSA), comprimento da raiz principal (CRP) e da parte aérea (CPA), de 16 genótipos tardios de soja, cul tivados em telado. Piracicaba, 1986.

\begin{tabular}{lccccc}
\hline & GL & \multicolumn{4}{c}{ Quadrados Médios } \\
\cline { 3 - 6 } & & \multicolumn{4}{c}{ Caracteres } \\
\cline { 3 - 6 } & & PSR & PSA & CRP & CPA \\
\hline Epocas (Ep) & 1 & 1,1616 & 0,6108 & 3,32 & 14189,89 \\
Blocos/Ep & 4 & $0,1718 * *$ & 0,0797 & $108,35 *$ & $1957,20 * *$ \\
Genótipos (G) & 15 & $0,0705 * *$ & 0,1337 & 44,19 & 209,05 \\
G x Ep & 15 & 0,0379 & 0,0776 & 13,72 & 198,14 \\
Residuo médio & 60 & 0,0236 & 0,0697 & 34,53 & 143,67 \\
\hline
\end{tabular}

*,**: significativo aos niveis de $5 \%$ e 18 de probabilidade, respectivamente, pelo teste $\mathrm{F}$. 
TABEla 43. Análise da variância, coeficiente de variação experimental (CV) e coeficiente de variação genotípica $\left(\mathrm{CV}_{\mathrm{G}}\right)$, para os caracteres peso seco de raizes (PSR) e da parte aérea (PSA), comprimento da raiz principal (CRP) e da parte aérea (CPA), de 16 genótipos tardios de soja, cultivados em telado. Piracicaba, 1986 .

\begin{tabular}{|c|c|c|c|c|c|}
\hline \multirow[t]{3}{*}{ FV } & \multirow[t]{3}{*}{ GL } & \multicolumn{4}{|c|}{ Quadrados Médios } \\
\hline & & \multicolumn{4}{|c|}{ Caracteres } \\
\hline & & PSR & PSA & $\mathrm{CRP}$ & CPA \\
\hline Blocos & 5 & 0,3510 & 1,0108 & 121,6 & 2783 \\
\hline Genōtipos & 15 & $0,0732 * \star$ & $0,1420 * \star$ & 54,1 & 161 \\
\hline Residuo & 75 & 0,0275 & 0,0417 & 39,2 & 81. \\
\hline $\mathrm{CV}$ (웅) & & 45 & 24 & 12 & 14 \\
\hline & & & & : & \\
\hline $\mathrm{CV}_{\mathrm{G}}\left(\frac{\circ}{0}\right)$ & & 23,9 & 15,1 & 3,0 & 5,5 \\
\hline
\end{tabular}

** : significativo ao nível de $1 \%$ de probabilidade, pelo teste $F$. 
TABELA 44. Médias de seis repetições, apra os caracteres peso seco de raízes (PSR) e da parte aérea (PSA), comprimento da raiz principal (CRP) e da parte aé rea (CPA), de 16 genótipos tardios de soja, cultí vados em telado. Piracicaba, 1986.

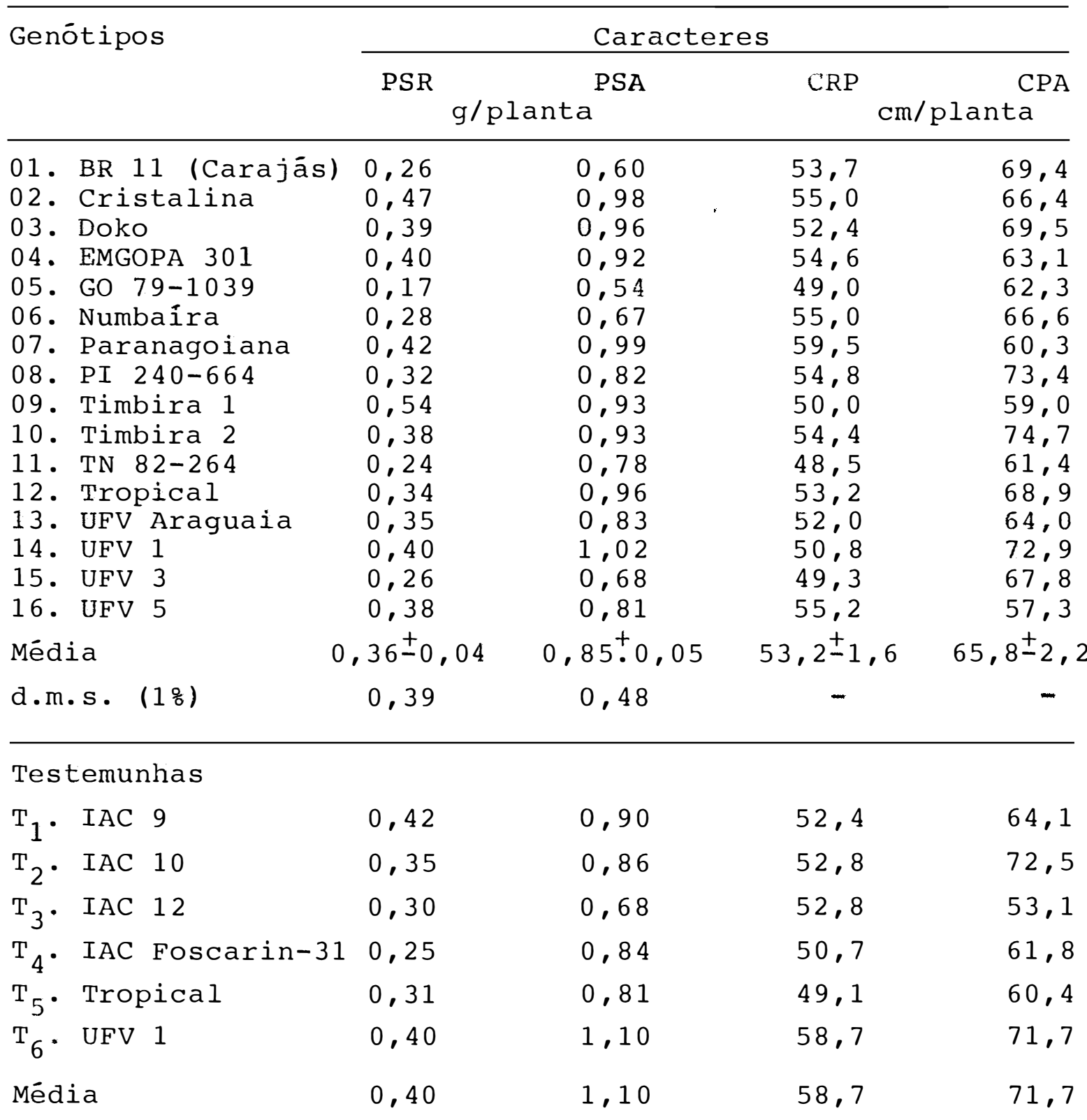

d.m.s.: diferença mínima significativa, pelo teste de Tukey. 


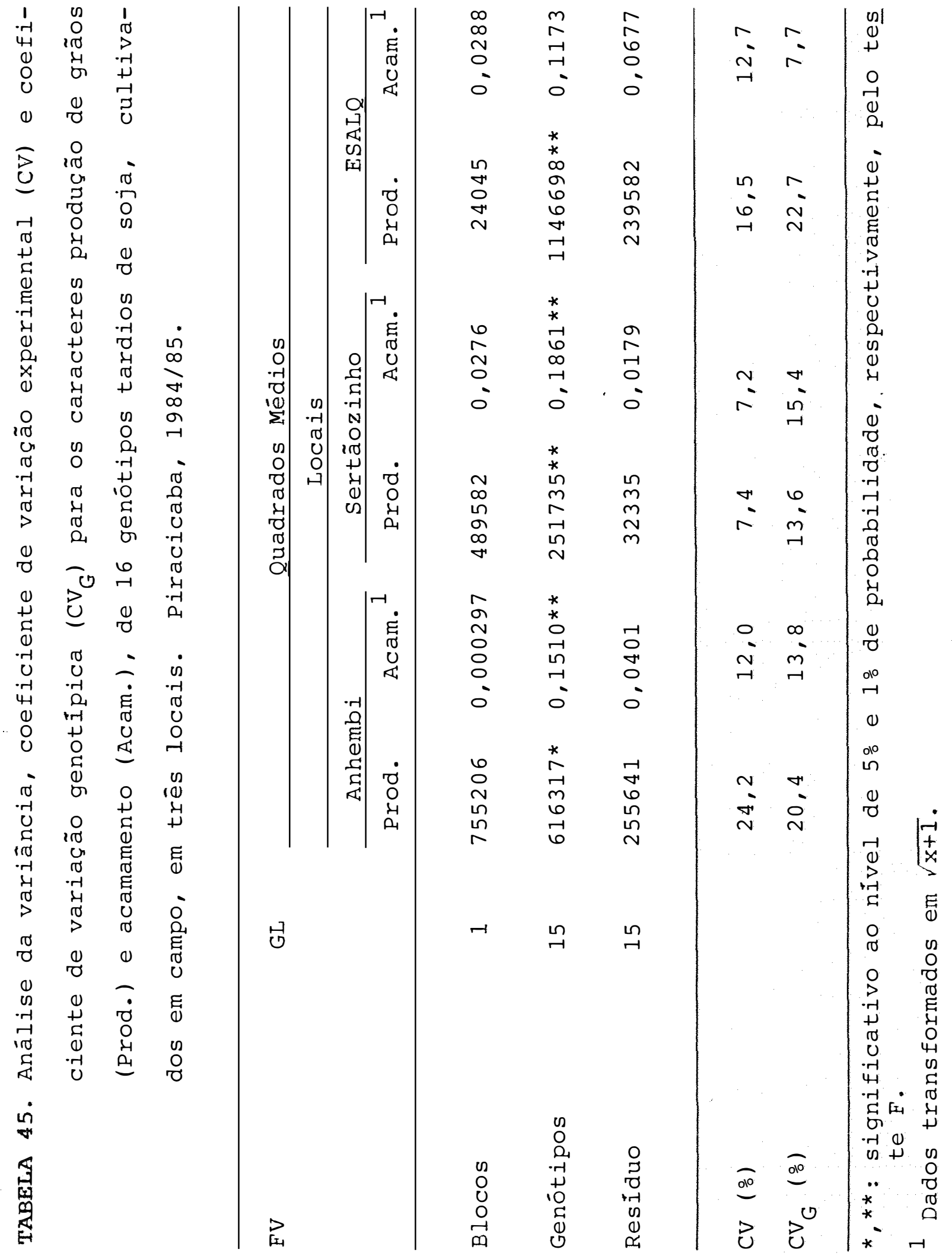


TABELA 46. Análise conjunta, para os três locais, para os ca racteres produção de grãos (Prod.) e acamamento (Acam.), de 16 genótipos de soja, cultivados em campo. Piracicaba, $1984 / 85$.

\begin{tabular}{|c|c|c|c|c|c|}
\hline \multirow[t]{2}{*}{ FV } & \multirow[t]{2}{*}{ GL } & \multicolumn{2}{|c|}{ Quadrado Médio } & \multirow[t]{2}{*}{ QM } & \multirow[t]{2}{*}{$\mathrm{F}$} \\
\hline & & Prod. & Acam. 1 & & \\
\hline & & & . & & \\
\hline Locais (L) & 2 & $6268643 *$ & $0,9565 * *$ & $Q_{5}$ & $Q_{5} / Q_{4}$ \\
\hline Blocos/L & 3 & 422742 & 0,0189 & $\mathrm{Q}_{4}$ & $Q_{4} / Q_{1}$ \\
\hline Genótipos (G) & 15 & 1481766 ** & $0,3674 * *$ & $Q_{3}$ & $Q_{3} / Q_{1}$ \\
\hline$G \times L$ & 30 & 266492 & 0,0435 & $\mathrm{Q}_{2}$ & $\mathrm{Q}_{2} / \mathrm{Q}_{1}$ \\
\hline Resỉduo médio & 45 & 175781 & 0,0419 & $\mathrm{Q}_{1}$ & \\
\hline
\end{tabular}

1 Dados transformados em $\sqrt{x+1}$

*, * : significativo aos niveis de $5 \frac{\circ}{0}$ e $1 \%$ de probabilidade, respectivamente, pelo teste $F$. 
TABELA 47. Média de duas repetições para os caracteres produ tividade de grãos (Prod.) e acamamento (Acam.) de 16 genótipos tardios de soja, avaliados em campo, em três locais. Piracicaba, $1984 / 85$.

\begin{tabular}{|c|c|c|c|c|c|c|}
\hline \multirow[t]{3}{*}{ Genötipos } & \multicolumn{6}{|c|}{ Locais } \\
\hline & \multicolumn{2}{|c|}{ Anhembi } & \multicolumn{2}{|c|}{ Sertãozinho } & \multicolumn{2}{|c|}{ ESALQ } \\
\hline & $\begin{array}{l}\text { Prod. } \\
\mathrm{kg} / \mathrm{ha}\end{array}$ & $\begin{array}{c}\text { Acam! } \\
\left(\begin{array}{lll}1 & \text { a } & 5\end{array}\right)\end{array}$ & $\begin{array}{l}\text { Prod. } \\
\mathrm{kg} / \mathrm{ha}\end{array}$ & $\begin{array}{c}\text { Acam! } \\
\left(\begin{array}{lll}1 & \text { a } & 5\end{array}\right)\end{array}$ & $\begin{array}{l}\text { Prod. } \\
\mathrm{kg} / \mathrm{ha}\end{array}$ & $\begin{array}{c}\text { Acam }{ }^{1} \\
\left(\begin{array}{lll}1 & \text { a } & 5\end{array}\right)\end{array}$ \\
\hline \multicolumn{7}{|l|}{$01 \cdot \mathrm{BR} 11$} \\
\hline (Carajās) & 2417 & 1,95 & 2229 & 2,24 & 3083 & 2,12 \\
\hline 02 . Cristalina & 2021 & 1,65 & 2750 & 1,82 & 2875 & 2,25 \\
\hline 03. Doko & 2104 & 1,82 & 2250 & 1,89 & 2792 & 2,26 \\
\hline 04 . EMGOPA 301 & 2437 & 1,73 & 2812 & 1,70 & 3583 & 2,26 \\
\hline 05. GO 79-1039 & 2021 & 1,49 & 2312 & 1,73 & 3292 & 2,06 \\
\hline 06 . Numbaira & 2292 & 1,49 & 2750 & 1,73 & 3583 & 1,98 \\
\hline \multicolumn{7}{|l|}{ 07. Parana- } \\
\hline 08. PI 240-664 & 2042 & 2,35 & 2271 & $\begin{array}{l}1,34 \\
2,25\end{array}$ & $\begin{array}{l}3604 \\
2333\end{array}$ & 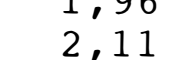 \\
\hline 09. Timbira 1 & 1771 & 1,65 & 1812 & 2,03 & 2812 & 2,24 \\
\hline 10. Timbira 2 & 1875 & 2,17 & 2250 & 2,28 & 3312 & 2,38 \\
\hline 11. TN 82-264 & 437 & 1,41 & 1625 & 1,41 & 542 & 1,41 \\
\hline 12. Tropical & 2521 & 1,91 & 2333 & 2,24 & 2458 & 2,26 \\
\hline 13. UFV Araguia & 2667 & 1,65 & 2583 & 2,01 & 3500 & 1,89 \\
\hline 14. UFV 1 & 2542 & 1,57 & 2729 & 1,73 & 3437 & 1,80 \\
\hline 15. UFV 3 & 2187 & 1,41 & 2625 & 1,41 & 2937 & 1,91 \\
\hline 16. UFV 5 & 2646 & 1,49 & 2625 & 1,49 & 3271 & 1,89 \\
\hline Média & $\begin{array}{c}2083^{ \pm} \\
126\end{array}$ & $\begin{array}{l}1,70 \pm \\
0,05\end{array}$ & $\begin{array}{c}2437 \pm \\
45\end{array}$ & $\begin{array}{l}1,85^{ \pm} \\
0,03\end{array}$ & $\begin{array}{c}2958 \pm \\
122\end{array}$ & $\begin{array}{l}2,05^{ \pm} \\
0,06\end{array}$ \\
\hline d.m.s. & 2000 & 0,99 & 875 & 0,66 & 2417 & - \\
\hline \multicolumn{7}{|l|}{ Testemunhas } \\
\hline $\mathrm{T}_{1} \cdot \operatorname{IAC} 9$ & 3271 & 1,12 & 2562 & 1,84 & 3167 & 2,27 \\
\hline $\mathrm{T}_{2} \cdot$ Tropical & 2146 & 2,21 & 2521 & 2,16 & 3146 & 2,21 \\
\hline $\mathrm{T}_{3} \cdot \mathrm{UFV} 1$ & 2354 & 1,45 & 2562 & 1,65 & 3250 & 1,73 \\
\hline Média & 2583 & 1,59 & 2542 & 1,88 & 3187 & 2,07 \\
\hline
\end{tabular}

$11=$ planta ereta; 5 = plantas prostrada.

Dados transformados em $\sqrt{x+1}$.

d.m.s. : diferença mínima significativa, pelo teste de Tukey. 
TABELA 48. Estimativas de coeficientes de correlação fenotípica $\left(r_{F}\right)$, ambiental $\left(r_{E}\right)$ e genotipica $\left(r_{G}\right)$, variāncia genotipica $\left(\mathrm{V}_{\mathrm{G}}\right)$ e coeficiente de determinação genotipica (b), para os caracteres peso seco de raízes (PSR) e da parte aérea (PSA), comprí mento da raiz principal ( $C R P$ ) e da parte aérea (CPA) de 16 genótipos tardios de soja cultivados em telado. Piracicaba, 1986.

\begin{tabular}{|c|c|c|c|c|c|}
\hline Caracteres & $r$ & PSR & PSA & $\mathrm{CRP}$ & $\mathrm{CPA}$ \\
\hline \multirow[t]{3}{*}{ PSR } & F & & 0,834 & 0,4678 & $-0,21$ \\
\hline & E & & 0,693 & 0,3219 & $-0,28$ \\
\hline & G & & 0,909 & 0,7240 & $-0,154$ \\
\hline \multirow[t]{3}{*}{ PSA } & $\mathrm{F}$ & & & 0,4139 & 0,0552 \\
\hline & E & & & 0,3526 & 0,0021 \\
\hline & G & & & 0,5704 & 0,0916 \\
\hline \multirow[t]{3}{*}{ CRP } & $\mathrm{F}$ & & & & $-0,0411$ \\
\hline & E. & & & & $-0,1210$ \\
\hline & G & & & & 0,0861 \\
\hline $\mathrm{v}_{\mathrm{G}}$ & & 0,00761 & 0,0167 & 2,48 & 13,38 \\
\hline $\mathrm{b}$ & & 0,623 & 0,706 & 0,274 & 0,498 \\
\hline
\end{tabular}


.150.

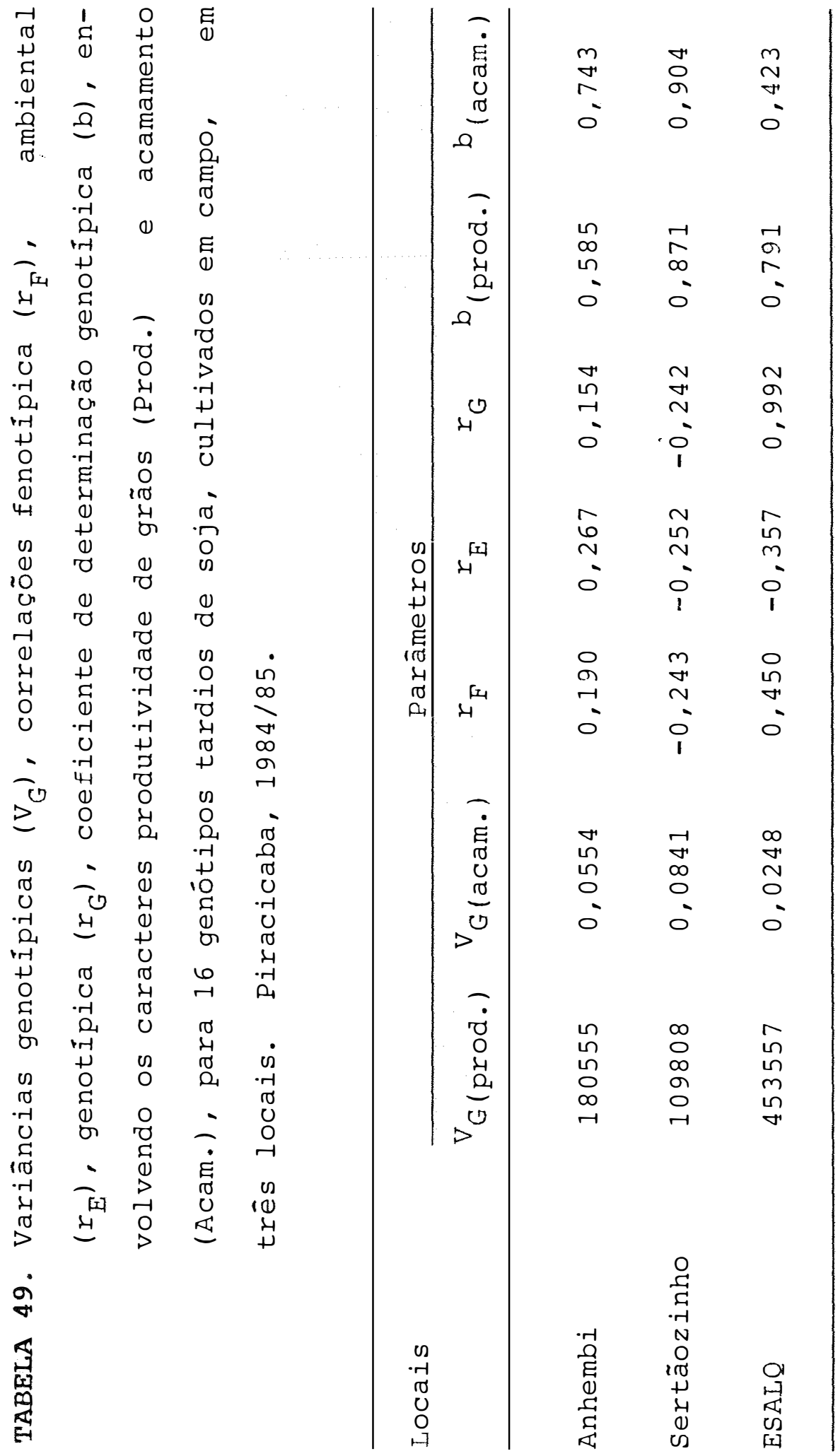


.151.

TABELA 50. Correlações intra-classe ( $\left.r_{I C}\right)$ entre os caracteres avaliados no telado - peso seco de raízes (PSR) e da parte aérea (PSA), comprimento da raiz principal e da parte aérea (CPA), com os avaliados no campo - produtividade de grãos (Prod.) e acamamento (Acam.) . Piracicaba, $1984 / 86$.

\begin{tabular}{lcccc} 
Caracteres & PSR & PSA & CRP & CPA \\
\hline Prod. & 0,0780 & 0,0186 & 0,1469 & 0,0475 \\
Acam. & 0,1049 & 0,1065 & 0,1469 & 0,2546
\end{tabular}







TABELA 52. Comportamento médio dos seis $F_{2}$ 's' de cinco $F_{1}$ 's de quatro parentais $\left(\mathrm{P}_{\mathrm{k}}\right)$, e de seis testemunhas

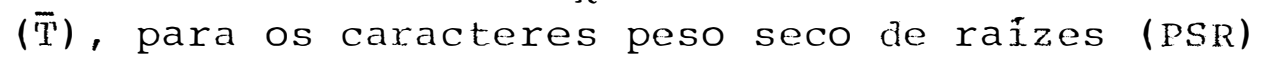
e da parte aérea (PSA), comprimento da raiz principal (CRP) e da parte aérea (CPA). Piracicaba, 1987.

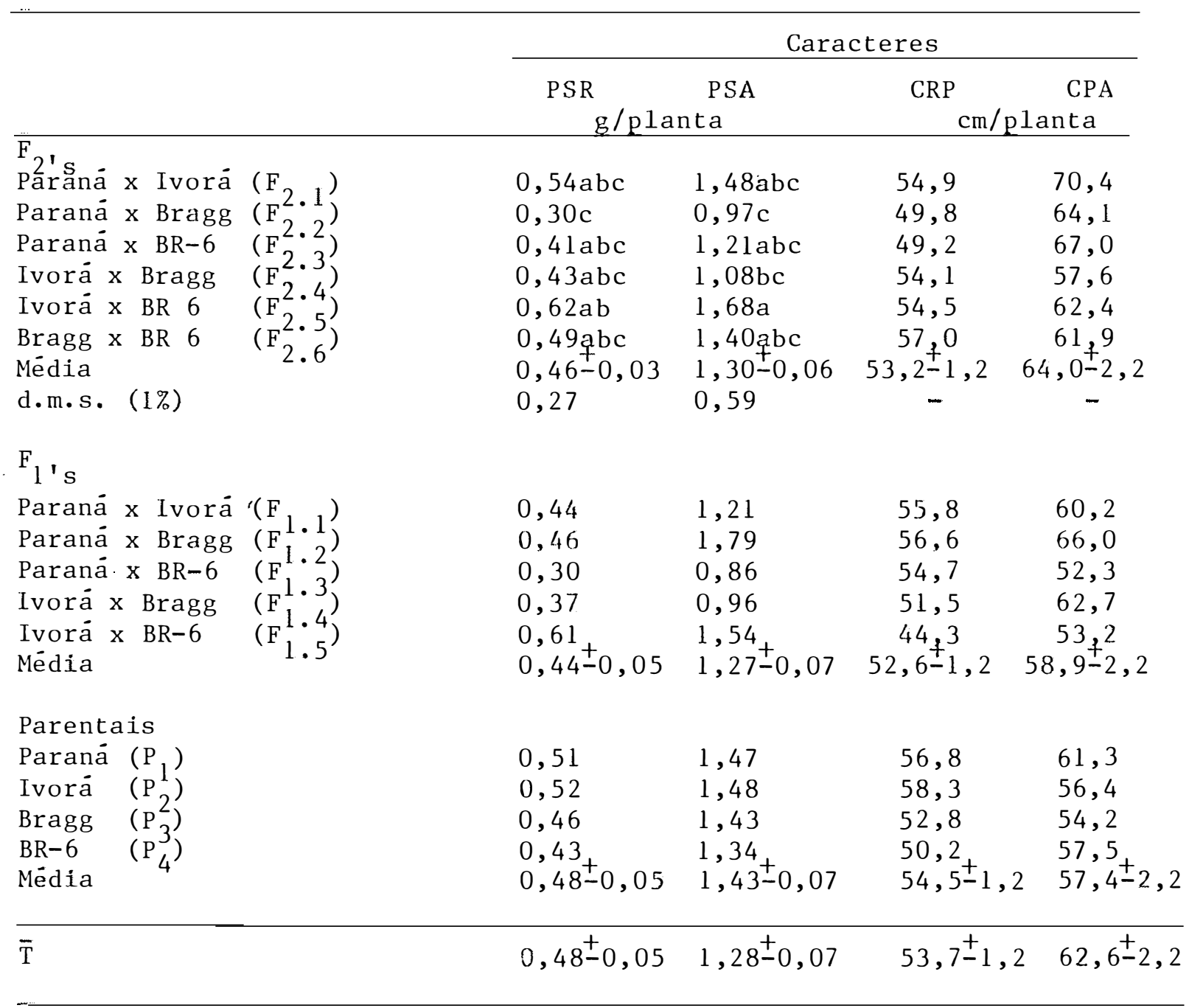

d.m.s. : diferença mínima significativa, pelo teste de Tukey. Médias com a mesma letra, não diferem, estatisticamente, entre si. 


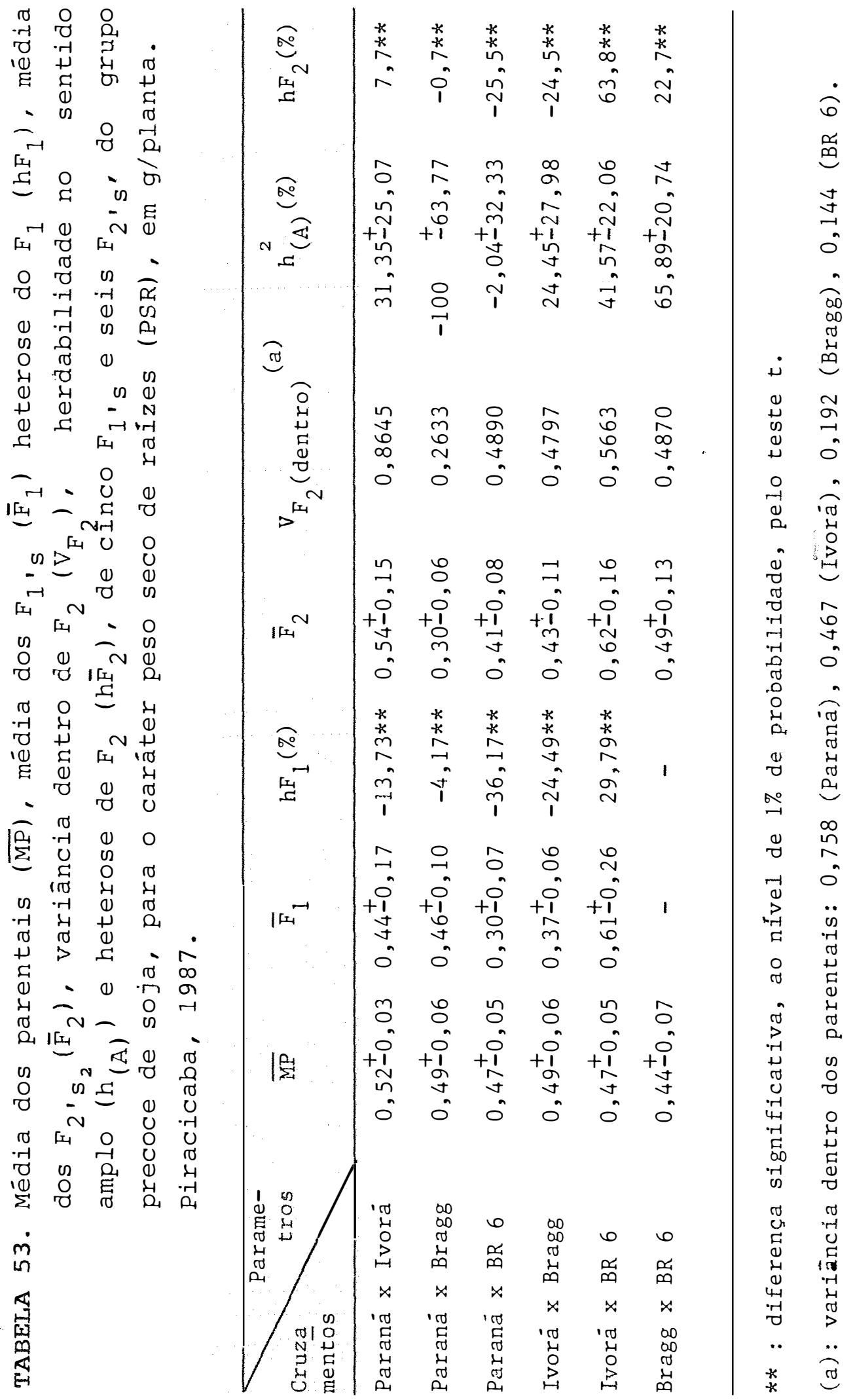




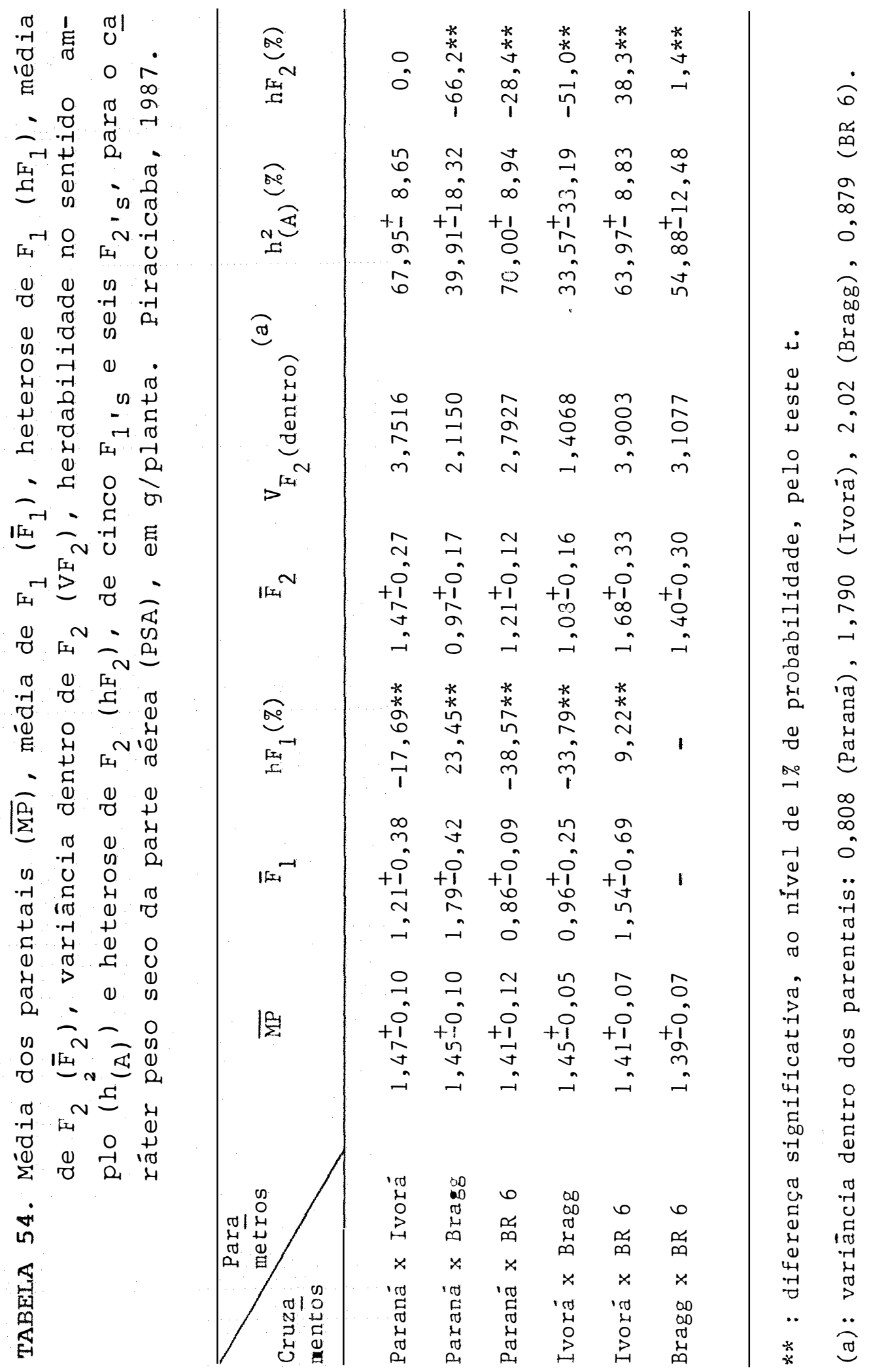




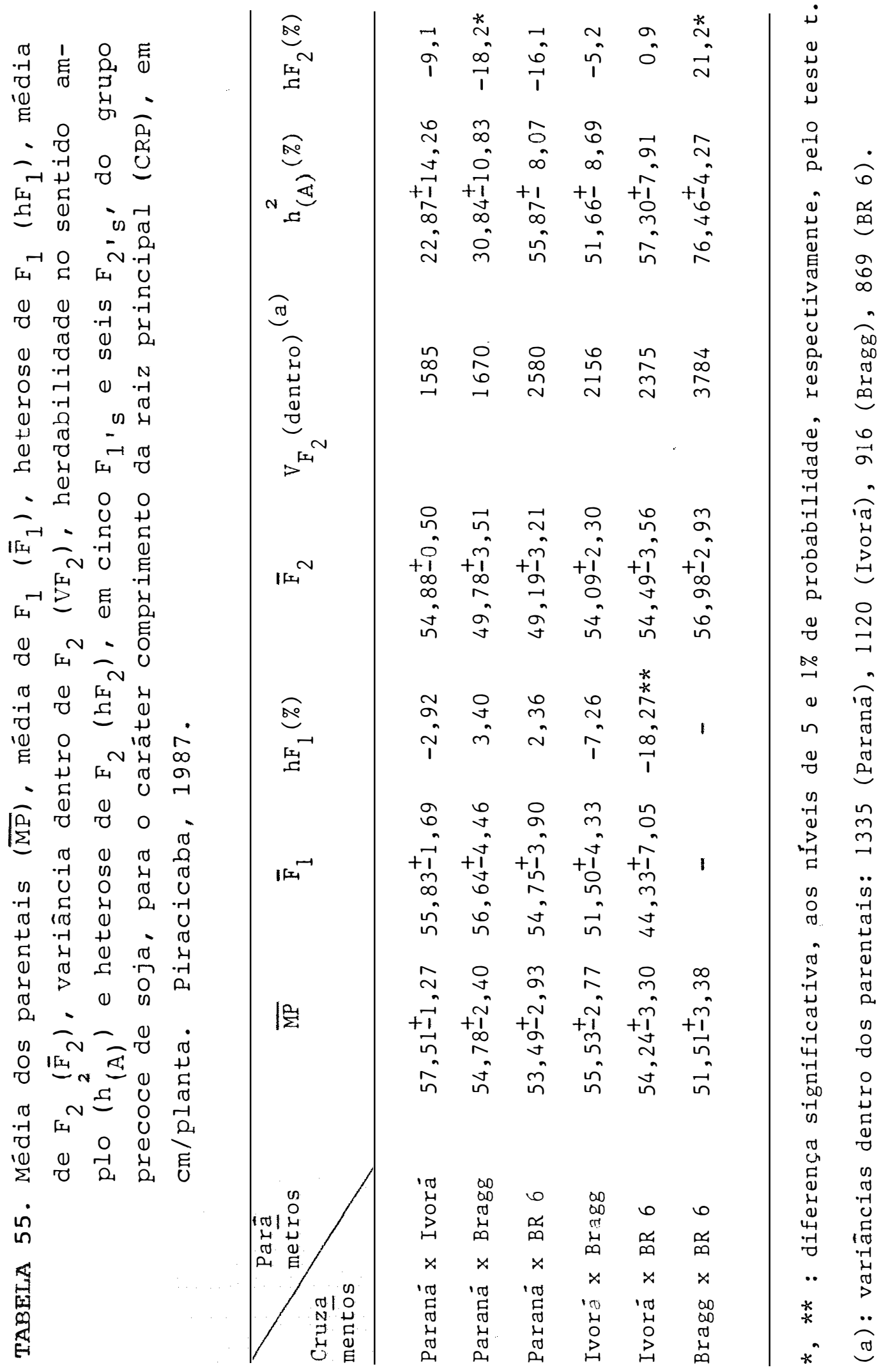




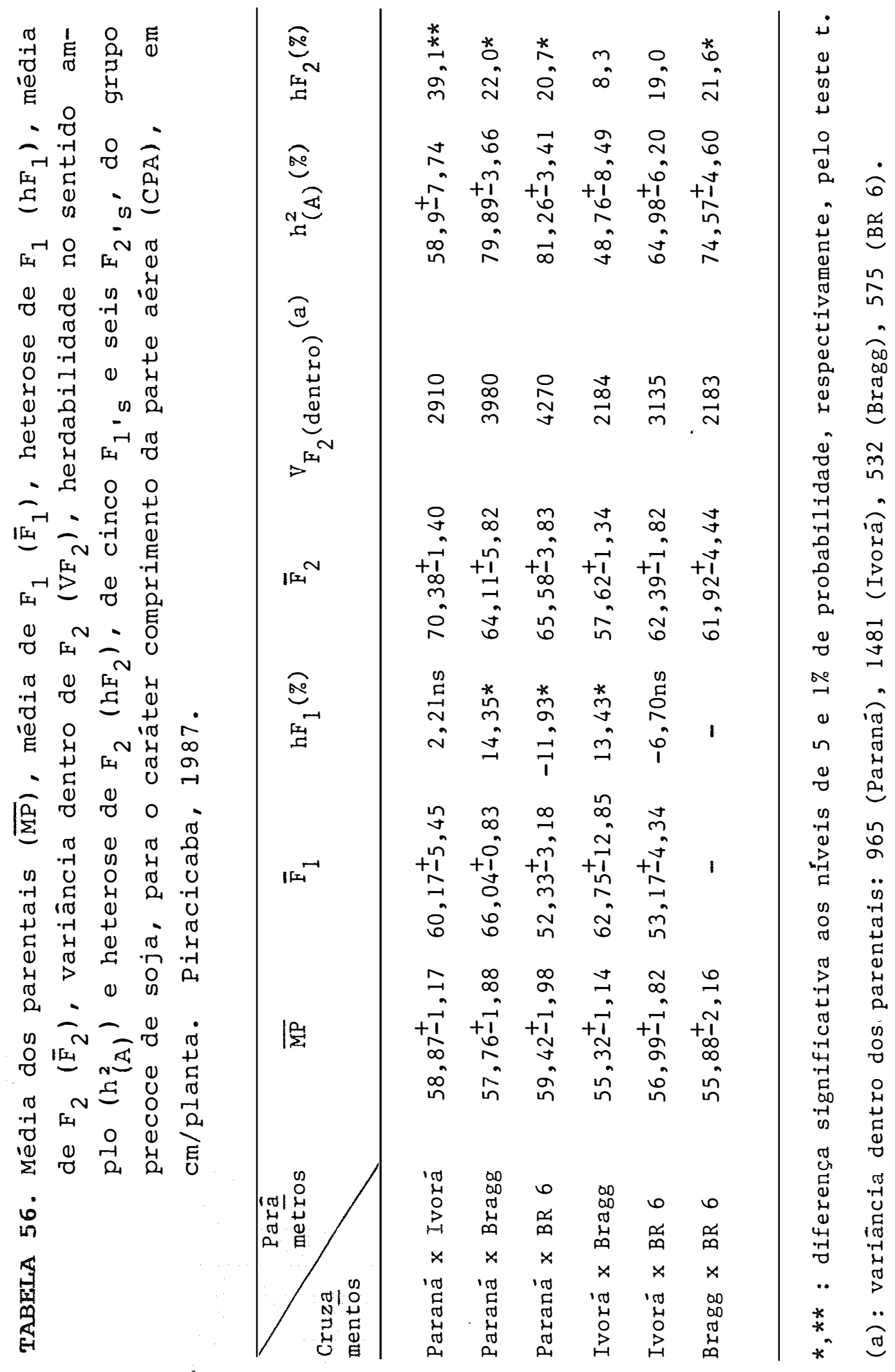


TABELA 57. Estimativas e coeficientes de correlação fenotipica $\left(r_{F}\right)$, ambiental $\left(r_{E}\right)$ e genotipica $\left(r_{G}\right)$, entre os caracteres peso seco de raizes (PSR) e da parte aērea (PSA), comprimento da raiz principal (CRP) e da parte aérea (CPA), em seis genótipos $F_{2}{ }^{\prime}$ ' do grupo precoce de soja. Piracicaba, 1987 .

\begin{tabular}{|c|c|c|c|c|c|}
\hline Caracteres & $r$ & PSR & PSA & CRP & $\mathrm{CPA}$ \\
\hline \multirow[t]{3}{*}{ PSR } & $\mathrm{F}$ & & 0,965 & 0,696 & 0,0793 \\
\hline & $\mathrm{E}$ & & 0,865 & 0,482 & $-0,2465$ \\
\hline & G & & 0,980 & 0,786 & 0,1720 \\
\hline \multirow[t]{3}{*}{ PSA } & $F$ & & & 0,603 & 0,2390 \\
\hline & $\mathrm{E}$ & & & 0,660 & 0,1403 \\
\hline & G & & & 0,617 & 0,2735 \\
\hline \multirow[t]{3}{*}{ CRP } & $\mathrm{F}$ & & & & $-0,2569$ \\
\hline & $\mathrm{E}$ & & & & 0,5168 \\
\hline & G & & & & $-0,6427$ \\
\hline
\end{tabular}


TABELA 58. Análise de variāncia para os quatro parentais e seis $\mathrm{F}_{2}$ 's' com desdobramento dos tratamentos em capacidade geral de combinação (CGC) e capacidade específica de combinação (CEC), para quatro caracteres de soja (PSR: peso seco de raizes; PSA: peso seco aéreo; CRP: comprimetno da raiz principal e CPA: comprimento da parte aérea), avaliados em telado. (Método 2, Modelo, B, GRIFFING, 1956).

\begin{tabular}{lccccc}
\hline & GL & \multicolumn{5}{c}{ Quadrados Médios } \\
\cline { 3 - 6 } & & PSR & PSA & CRP & CPA \\
\hline Tratamentos & 9 & $0,02308^{*}$ & $0,13321 * *$ & 30,61 & $75,55^{*}$ \\
CGC & 3 & 0,02136 & 0,07540 & 32,03 & $88,36 *$ \\
CEC & 6 & $0,02394^{*}$ & $0,16211 * *$ & 30,00 & $69,15 *$ \\
Residuo & 18 & 0,00675 & 0,03035 & 20,80 & 18,10 \\
\hline
\end{tabular}

*,**: significativo ao nível de 5웅 e 1용 de probabilidade, res pectivamente, pelo teste F. 
TABELA 59. Estimativas das capacidades geral $\left(\bar{g}_{i}\right)$ e específi ca $\left(\hat{s}_{i j}\right)$ de combinação para os caracteres peso seco de raízes (PSA) e da parte aérea (PSA), comprimento da raiz principal (CRP) e da parte aérea (CPA) de seis $F_{2}$ 's' do grupo precoce de soja, obtidos através da análise dialélica de GRIFFING $(1956)$

\begin{tabular}{cccc}
\hline Parâmetros & PSR & PSA & CRP \\
g/planta & $\mathrm{cm} / \mathrm{planta}$
\end{tabular}

\begin{tabular}{lrrrr}
\hline$\hat{g}_{1}$ (Paraná) & $-0,0139$ & $-0,0280$ & $-0,2253$ & 2,9439 \\
$\hat{g}_{2}$ (Ivorá) & 0,0467 & 0,0697 & 1,8769 & $-0,5378$ \\
$\hat{g}_{3}$ (Bragg) & $-0,0344$ & $-0,0758$ & $-0,3786$ & $-2,4022$ \\
$\hat{g}_{4}$ (BR 6) & 0,0017 & 0,0342 & $-1,2704$ & $-0,0039$ \\
$\hat{s}_{1.2}$ & 0,0352 & 0,0800 & $-0,5204$ & 6,6799 \\
$\hat{s}_{1.3}$ & $-0,1203$ & $-0,2811$ & $-3,3618$ & 2,2677 \\
$\hat{s}_{1.4}$ & $-0,0531$ & 0,1478 & $-3,0540$ & 2,8160 \\
$\hat{s}_{2.3}$ & $-0,0542$ & 0,2655 & $-1,1573$ & $-0,7340$ \\
$\hat{s}_{2.4}$ & 0,1030 & 0,2211 & 0,1438 & 1,6376 \\
$\hat{s}_{3.4}$ & 0,0541 & 0,0867 & 4,8893 & 3,0321 \\
\hline
\end{tabular}


.16.
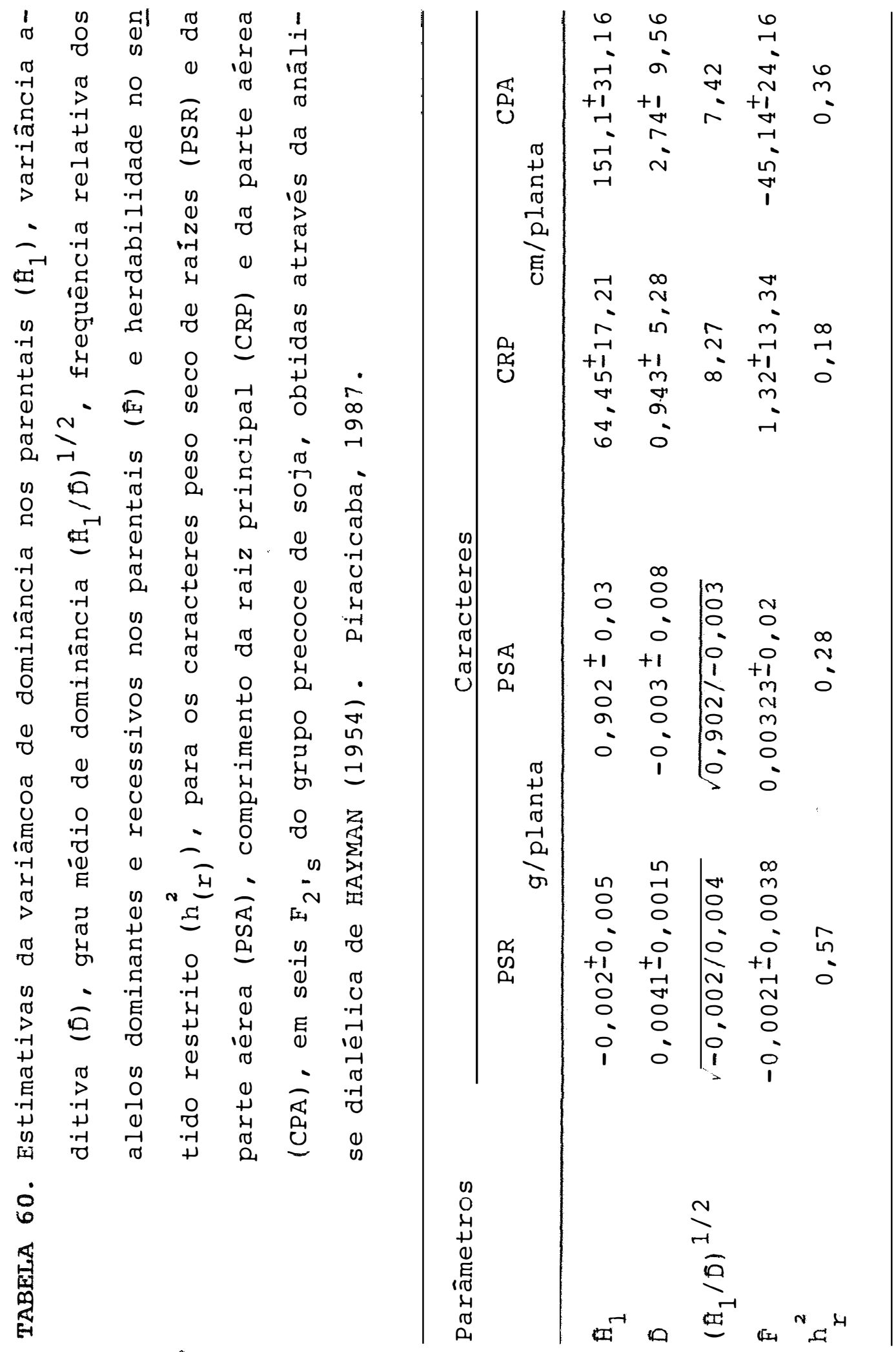
.162.

A P E 
APENDICE 1. Composição química da solução nutritiva (ml/I) (SARRUGE, 1970).

Soluções estoquea /

ml/litro de āgua

\begin{tabular}{lll}
$\mathrm{KH}_{2} \mathrm{PO}_{4}$ & $\mathrm{M}$ & 1 \\
$\mathrm{KNO}_{3}$ & $\mathrm{M}$ & 5 \\
$\mathrm{Ca}\left(\mathrm{NO}_{3}\right)_{2}$ & $\mathrm{M}$ & 5 \\
$\mathrm{MgSO}_{4}$ & $\mathrm{M}$ & 2 \\
$\mathrm{Micronutrientes}^{\mathrm{b} /}$ & & 1 \\
Fe-EDTA & & 1 \\
\hline
\end{tabular}

a/ Preparados pela dissolução de 1 M da substāncia completan do-se para um litro.

b/ A solução de micronutrientes tem a seguinte composição $(\mathrm{g} / \mathrm{l}): \mathrm{H}_{3} \mathrm{BO}_{3}, 2,86 ; \mathrm{MnCl}_{2} \cdot 4 \mathrm{H}_{2} \mathrm{O}, 1,81 ; \mathrm{ZnCl}_{2}, 0,10 ; \mathrm{CuCl}_{2}$, 0,$04 ; \mathrm{H}_{2} \mathrm{MOO}_{4} \cdot \mathrm{H}_{2} \mathrm{O}, 0,02$.

c/ Fe-FDTA: dissolver 26,1 g de EDTA dissódico em $286 \mathrm{ml}$ de $\mathrm{NaOH} \mathrm{N}$, misturar com $24,9 \mathrm{~g}$ de $\mathrm{FeSO}_{4} \cdot 7 \mathrm{H}_{2} \mathrm{O}$. Arejar por uma noite e completar para um litro. 
APENDICE 2. Análises químicas dos solos dos três locais dos experimentos de campo. Piracicaba, $1984 / 1985$.

\begin{tabular}{llllllllllll}
\hline Local & $\mathrm{pH}$ & $\mathrm{C} \%$ & $\mathrm{Ca}$ & $\mathrm{Mg}$ & $\mathrm{Ca}+\mathrm{Mg}$ & $\mathrm{K}$ & $\mathrm{PO}_{4}^{-3}$ & $\mathrm{H}$ & $\mathrm{Al}^{+3}$ & $\mathrm{H}+\mathrm{Al}$ \\
& & & & & & & mLliequivalente/100 & $\mathrm{g}$ de solo & - \\
\hline ESALQ $^{\mathrm{a}}$ & 6,0 & 1,30 & 7,07 & 1,26 & - & 0,09 & 0,03 & - & 0,11 \\
Sertãozinho $^{\mathrm{b}}$ & 4,3 & 0,38 & 0,14 & 0,02 & - & 0,06 & 0,03 & - & 1,80
\end{tabular}

miliequivalente/100 ml de solo

Anhembi $^{\mathrm{C}} \quad 4,6 \quad 1,20 \quad$ - $\quad$ - $\quad 1,80 \quad 0,190,04 \quad 4,80 \quad 1,80$ -

a Local ESALQ, Série Luiz de Queiroz; Ultic Ultustalf Fonte: RANZANI et alii (1.966)

b Local Sertãozinho, Série Sertãozinho Haplustox Fonte: RANZANI et alii (1966)

C Local Anhembi: Fonte: SILVA (1980).

APENDICE 3. Dados meteorológicos no período de permanência dos experimentos em campo. Piracicaba, 1984/85.

\begin{tabular}{|c|c|c|c|c|c|c|}
\hline \multirow[t]{2}{*}{ Dados meteorolögicos } & \multicolumn{3}{|c|}{1984} & \multicolumn{3}{|c|}{1985} \\
\hline & Out. & Nov. & Dez. & Jan. & Fev. & Mar. \\
\hline Precipitação (mm/mēs) & 27,4 & 201,1 & 196,0 & 131,8 & 118,6 & 203,1 \\
\hline Temperatura média $\left({ }^{\mathrm{O}} \mathrm{C}\right)$ & 23,8 & 24,5 & 23,7 & 23,8 & 25,6 & 24,4 \\
\hline Und dade relat iva mëdia (\%) & 66,2 & 73,3 & 79,4 & 81,5 & 81,4 & 78, \\
\hline Insolação média (hora/dia) & 8,4 & 7,2 & 5,5 & 5,4 & 6,0 & 6,1 \\
\hline
\end{tabular}

Fonte: Departamento de Fisica e Meteorologia da ESALQ/USP. 